\title{
Simulation of Groundwater Flow in the Aquifer System of the Anacostia River and Surrounding Watersheds, Washington, D.C., Maryland, and Virginia
}

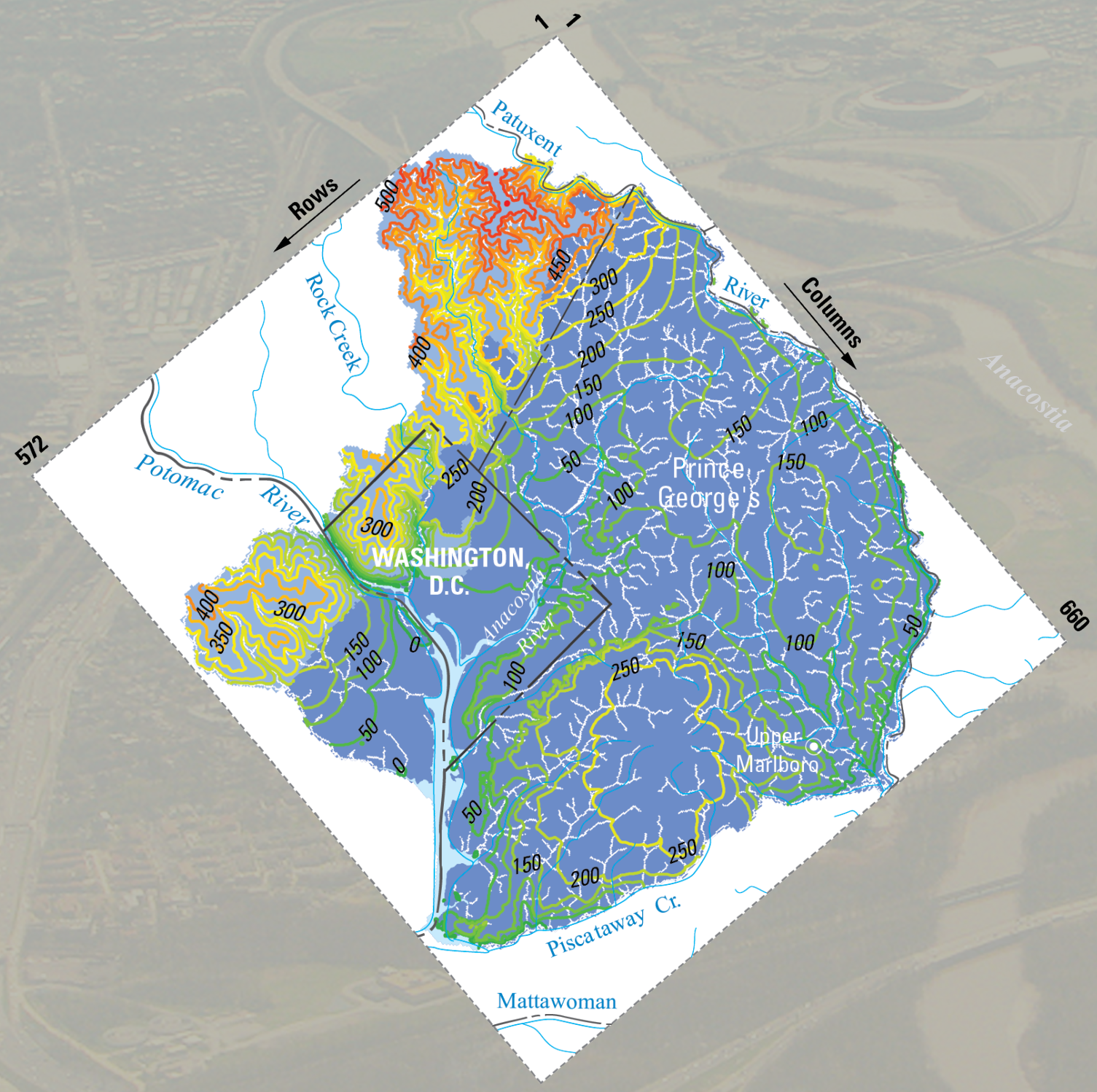

Scientific Investigations Report 2013-5225

U.S. Department of the Interior

U.S. Geological Survey 
Cover. The simulated water table for the model domain represented by water levels in layer 1 (surficial aquifer) and the outcrop area of layer 8 (Piedmont weathered rocks). (Refer to figure 18.) Background image is aerial photograph of the Anacostia River looking west toward the Potomac River. 


\section{Simulation of Groundwater Flow in the Aquifer System of the Anacostia River and Surrounding Watersheds, Washington, D.C., Maryland, and Virginia}

By Jeff P. Raffensperger, Lois M. Voronin, and Cheryl A. Dieter

Scientific Investigations Report 2013-5225 


\section{U.S. Geological Survey, Reston, Virginia: 2021}

For more information on the USGS — the Federal source for science about the Earth, its natural and living resources, natural hazards, and the environment-visit https://www.usgs.gov or call 1-888-ASK-USGS.

For an overview of USGS information products, including maps, imagery, and publications, visit https://store.usgs.gov.

Any use of trade, firm, or product names is for descriptive purposes only and does not imply endorsement by the U.S. Government.

Although this information product, for the most part, is in the public domain, it also may contain copyrighted materials as noted in the text. Permission to reproduce copyrighted items must be secured from the copyright owner.

Suggested citation:

Raffensperger, J.P., Voronin, L.M., and Dieter, C.A., 2021, Simulation of groundwater flow in the aquifer system of the Anacostia River and surrounding watersheds, Washington, D.C., Maryland, and Virginia: U.S. Geological Survey Scientific Investigations Report 2013-5225, 59 p., https://doi.org/10.3133/sir20135225.

ISSN 2328-031X (print) ISSN 2328-0328 (online) ISBN 978-1-4113-3766-4 


\section{Acknowledgments}

This work was conducted in cooperation with the District Department of Energy \& Environment (DOEE), Water Quality Division. The authors thank Diane Douglas and other staff at DOEE for their support of the study. Mary Hill, Claire Tiedeman, Rod Sheets, and Chris Langevin (USGS) provided technical support for MODFLOW-NWT and UCODE_2005 and suggestions for improving model calibration. Stephen Cauller and Anthony Lopez (USGS) assisted in the preparation of model input data files. Susan Colarullo (USGS) developed a program integrating a geographic information system (GIS) that corrected land-surface elevations in model cells underlying streams so that elevations decreased monotonically towards the basin outlet. Andrew Sekellick and Andrew Lamotte (USGS) developed scripts that aided in calculating layer elevations and provided other GIS assistance. Wendy McPherson provided water withdrawal data. In addition, the authors thank Valerie Gaine (USGS) for editorial and publishing assistance, Tim Auer (formerly of USGS) for his work on the illustrations, and Sarah Lighter (USGS) for completing the layout. Finally, the authors thank Susan Colarullo, Jack Eggleston, Paul Juckem, Rod Sheets, and Kevin Breen (USGS) for thorough and thoughtful technical reviews of the manuscript and model archive. Their suggestions greatly improved the report. 


\section{Contents}

Acknowledgments .......................................................................................................................ii

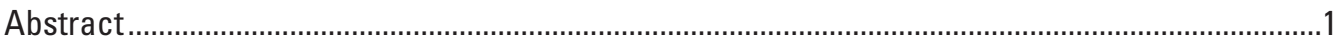

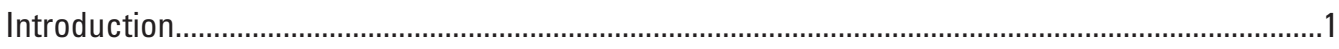

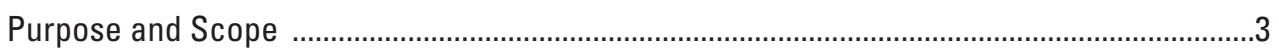

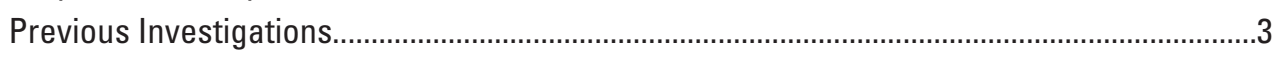

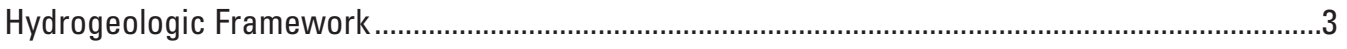

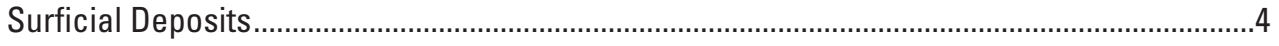

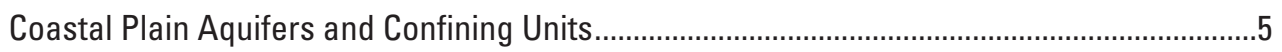

Piedmont

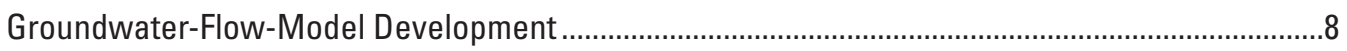

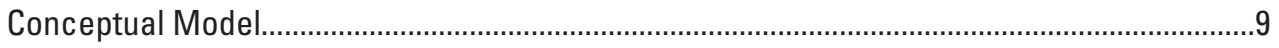

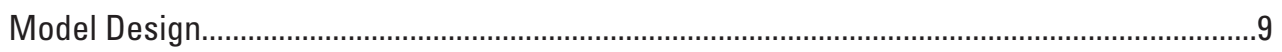

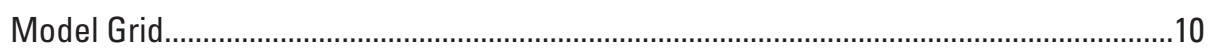

Layering and Zonation .......................................................................................11

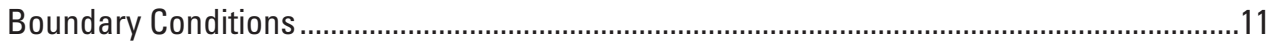

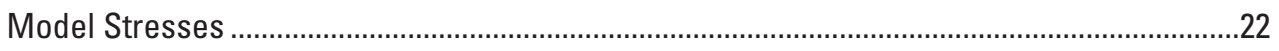

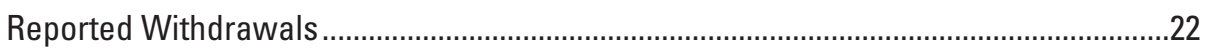

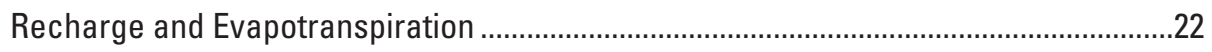

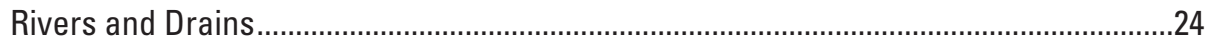

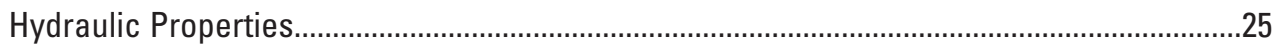

Model Calibration and Sensitivity Analysis Approach ................................................................26

Nonlinear Least-Squares Regression Method ................................................................26

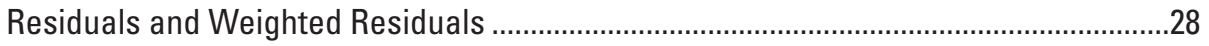

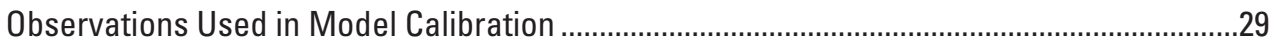

Water Levels and Associated Errors...........................................................................29

Streamflow Observations and Associated Errors .........................................................

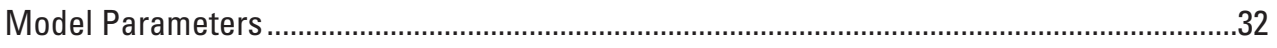

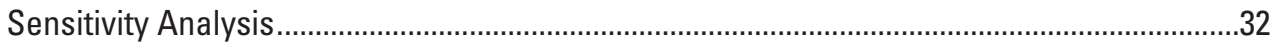

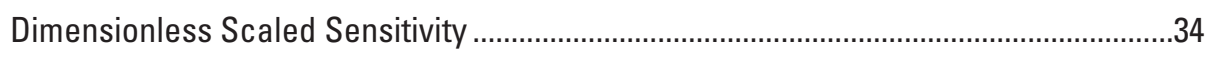

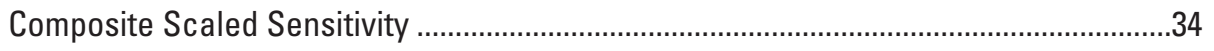

Parameter Correlation Coefficient................................................................................34

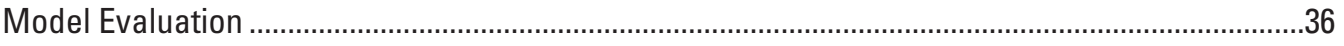

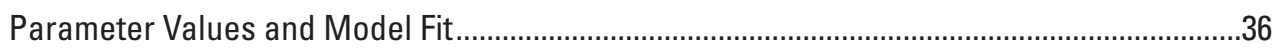

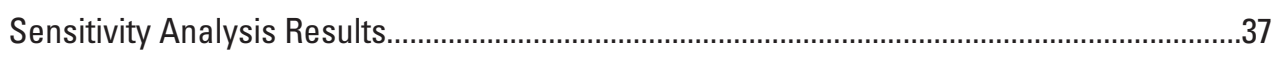

Simulated Water Table and Flow Patterns Near the Tidal Anacostia River ............................41

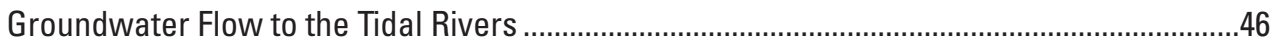

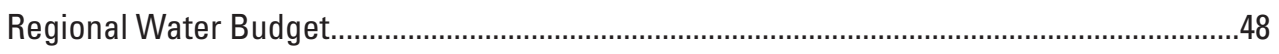

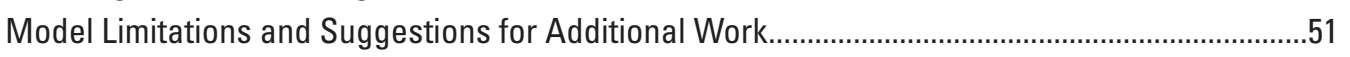

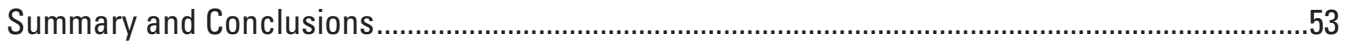

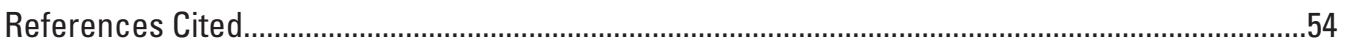




\section{Figures}

1. Map showing location of the Anacostia River watershed and model domain ..............2

2. Map showing distribution of surficial geologic units in Washington, D.C., Maryland, and Virginia

3. Diagram showing conceptual model of the groundwater-flow system in the Anacostia River and surrounding watersheds, showing schematic layering, location of boundary conditions, zone designations, and initial model hydraulic and other property values.

4. Map showing layer extent and features, model layer 1 (surficial aquifer)..................12

5. Map showing layer extent and features, model layer 2 (Aquia aquifer) ......................13

6. Map showing layer extent and features, model layer 3 (confining unit/Magothy aquifer).

7. Map showing layer extent and features, model layer 4 (upper Patapsco aquifer).....15

8. Map showing layer extent and features, model layer 5 (Patapsco confining unit).....16

9. Map showing layer extent and features, model layer 6 (lower Patapsco aquifer/ Arundel Clay)

10. Map showing layer extent and features, model layer 7 (Patuxent aquifer) .18

11. Map showing layer extent and features, model layer 8 (weathered Piedmont bedrock).

12. Map showing layer extent and features, model layer 9 (unweathered Piedmont bedrock)

13. Map showing streamgages and watersheds used in model calibration

14. Graphs showing simulated and observed values for the final calibrated model: $(A)$ water levels; $(B)$ stream base flows

15. Bar graph showing frequency distribution and empirical quantile-quantile plots of weighted residuals for the final calibrated model: $(A)$ frequency distribution of weighted water-level residuals with fitted normal distribution; $(B)$ empirical quantile-quantile plot of weighted water-level residuals; $(C)$ frequency distribution of weighted stream base-flow residuals with fitted normal distribution, and (D) empirical quantile-quantile plot of weighted stream base-flow residuals.

16. Map showing magnitude and distribution of weighted residuals for observations of water levels in well

17. Bar graph showing composite scaled sensitivities (css) for the seven estimated model parameters

18. Map showing the simulated water table for the model domain represented by water levels in layer 1 (surficial aquifer) and the outcrop area of layer 8 (Piedmont weathered rocks)

19. Map showing the simulated water table for Washington, D.C. represented by water levels in layer 1 (surficial aquifer) and the outcrop area of layer 8 (Piedmont weathered rocks)

20. Graphs showing calibrated horizontal hydraulic conductivity and simulation results for heads in cross sections $(A) A-A^{\prime},(B) B-B^{\prime}$, and $(C) C-C^{\prime}$

21. Map showing simulated base flow to constant-head cells representing tidal rivers in the model

22. Map showing simulated base flow to constant-head cells representing tidal rivers in Washington, D.C. 
23. Map showing zones created for Washington, D.C. and tidal waters within Washington, D.C.

24. Pie charts of the $(A)$ outflows and $(B)$ inflows of groundwater computed by the calibrated steady-state model for the Anacostia River.

\section{Tables}

1. Surficial geologic units and descriptions for the Washington, D.C. area

2. Summary of rules for determining layer elevations, including choices of Aquifer Information System (AIS) layers adopted for each flow model layer

3. Description of Aquifer Information System (AIS) hydrogeologic framework units and subcrop/outcrop areas corresponding to model zones

4. Withdrawal wells used in the model, including model cell location and 2005 reported pumpage

5. Sources of data for initial hydraulic property values for the Anacostia, Potomac, and Patuxent River watershed model, Washington, D.C. and Maryland ....

6. Lithologic classification and initial hydraulic conductivity values for materials in model layer 1 .....

7. Observation wells used to calibrate the groundwater-flow model, with associated observations, errors (variance), weights, and weighted observations

8. Streamgages used to calibrate the groundwater-flow model, with associated observations, errors (variance), weights, and weighted observations .................................34

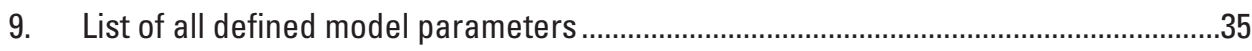

10. Final parameter values and fit-independent statistics...................................................36

11. Observed and simulated values for water levels and stream base flows, with calculated residuals, and weighted observed, simulated, and residual values 38

12. Optimal values, confidence intervals, and coefficients of variation for the estimated model parameters.

13. Dimensionless scaled sensitivity $(d s s)$ values for all observations for the seven estimated model parameters, with maximum absolute values for both parameters and observations.

14. Water budget computed by the calibrated steady-state model, Anacostia River and surrounding watersheds

15. Water budget for the groundwater system computed by the calibrated steady-state model for Washington, D.C., including tidal waters 


\section{Conversion Factors}

U.S. customary units to International System of Units

\begin{tabular}{|c|c|c|}
\hline Multiply & By & To obtain \\
\hline \multicolumn{3}{|c|}{ Length } \\
\hline inch (in.) & 2.54 & centimeter $(\mathrm{cm})$ \\
\hline inch (in.) & 25.4 & millimeter $(\mathrm{mm})$ \\
\hline foot $(\mathrm{ft})$ & 0.3048 & meter $(\mathrm{m})$ \\
\hline mile (mi) & 1.609 & kilometer $(\mathrm{km})$ \\
\hline \multicolumn{3}{|c|}{ Area } \\
\hline square mile $\left(\mathrm{mi}^{2}\right)$ & 2.590 & square kilometer $\left(\mathrm{km}^{2}\right)$ \\
\hline \multicolumn{3}{|c|}{ Volume } \\
\hline gallon (gal) & 3.785 & liter (L) \\
\hline gallon (gal) & 0.003785 & cubic meter $\left(\mathrm{m}^{3}\right)$ \\
\hline million gallons (Mgal) & 3,785 & cubic meter $\left(\mathrm{m}^{3}\right)$ \\
\hline \multicolumn{3}{|c|}{ Flow rate } \\
\hline gallon per day (gal/d) & 0.003785 & cubic meter per day $\left(\mathrm{m}^{3} / \mathrm{d}\right)$ \\
\hline million gallons per day (Mgal/d) & 0.04381 & cubic meter per second $\left(\mathrm{m}^{3} / \mathrm{s}\right)$ \\
\hline cubic foot per day $\left(\mathrm{ft}^{3} / \mathrm{d}\right)$ & 0.02832 & cubic meter per day $\left(\mathrm{m}^{3} / \mathrm{d}\right)$ \\
\hline \multicolumn{3}{|c|}{ Hydraulic conductivity } \\
\hline foot per day (ft/d) & 0.3048 & meter per day $(\mathrm{m} / \mathrm{d})$ \\
\hline
\end{tabular}

\section{Datum}

Vertical coordinate information is referenced to the North American Vertical Datum of 1988 (NAVD 88).

Horizontal coordinate information is referenced to North American Datum of 1983 (NAD 83).

Latitude and longitude are expressed in degrees-minutes-seconds or in decimal degrees. When expressing longitude in decimal degrees, the West/East suffix is replaced by a negative sign in the Western Hemisphere.

Altitude, as used in this report, refers to distance above the vertical datum.

Water Year, as used in this report, begins on October 1 and runs through the following September 30. 



\title{
Simulation of Groundwater Flow in the Aquifer System of the Anacostia River and Surrounding Watersheds, Washington, D.C., Maryland, and Virginia
}

\author{
By Jeff P. Raffensperger, Lois M. Voronin, and Cheryl A. Dieter
}

\begin{abstract}
The U.S. Geological Survey, in cooperation with the District Department of Energy \& Environment, Water Quality Division, is investigating the hydrogeology of the tidal Anacostia River watershed within Washington, D.C., with the goal of improving understanding of the groundwater-flow system and the interaction of groundwater and surface water in the watershed. To help meet this goal, a three-dimensional steady-state groundwater-flow model for the Anacostia River and surrounding watersheds in Washington, D.C., Maryland, and Virginia was constructed. The goal of the modeling study was to quantify the rate and pattern of groundwater flow to the tidal Anacostia River. The model domain includes weathered and unweathered rocks of the Piedmont Physiographic Province and the southeast-dipping sediments of the Atlantic Coastal Plain Physiographic Province. The model includes processes of recharge, evapotranspiration, withdrawals from wells, and base flow to streams, rivers, and tidal waters. Final model calibration was achieved by using the objective parameter estimation and sensitivity analysis capabilities of UCODE_2005. Simulated gradients in the surficial aquifer in the vicinity of the tidal Anacostia River indicate that flow is predominantly toward the river, with changes in the magnitude and direction of the gradients from the northeast, where the Anacostia River enters Washington, D.C., to the southwest, toward the confluence with the tidal Potomac River. Flow paths to the tidal Anacostia River from the north are largely horizontal through the surficial aquifer and Patuxent aquifer. From the south, the flow paths toward the river originate in the elevated topographic areas southeast of the river and pass through the surficial aquifer and Patapsco confining unit, lower Patapsco aquifer/Arundel Clay, and to some extent, the Patuxent aquifer. Groundwater-flow rates to and from the tidal rivers (Potomac and Anacostia) are generally greatest near the land-water boundary, where the gradient in the water table is greatest, and diminish toward the middle of the tidal river channels. The tidal rivers are predominantly areas of groundwater discharge, although there are areas where tidal waters are recharging the subsurface, typically where small variations or depressions in the topography produce small locally reversed gradients in the water table. Substantial recharge of
\end{abstract}

tidal waters to the groundwater system is observed for the tidal Potomac where the upper Patapsco aquifer subcrops south of Washington, D.C. Water budget calculations indicate that inflows to the groundwater system beneath the tidal Anacostia River are predominantly from the land area of Washington, D.C., followed by tidal surface water and flows from lower layers. Outflows are largely to the tidal Anacostia River, with a smaller part going to the land area underlying Washington, D.C.

\section{Introduction}

The U.S. Geological Survey (USGS), in cooperation with the District Department of Energy \& Environment (DOEE), Water Quality Division, is investigating groundwater hydrogeology in the tidal Anacostia River watershed within Washington, D.C. The goal of the investigation is to improve understanding of the groundwater-flow system and groundwater-surface-water interaction in the tidal Anacostia River watershed (fig. 1).

As part of this study, a three-dimensional regional groundwater-flow model was developed by synthesizing existing hydrogeologic information for the Anacostia River and surrounding watersheds. The model results were used to quantify the rate and pattern of groundwater flow to the tidal Anacostia River. DOEE is responsible for protecting the water resources of Washington, D.C.; this flow model is another tool to help DOEE manage the groundwater resources in Washington, D.C. Additionally, the surficial aquifer in Washington, D.C. is the main source of recharge to deeper confined aquifers, which are major sources of groundwater for drinking or other water supplies in the region. The surficial aquifer also is a major source of base flow to local streams within Washington, D.C. This base flow helps maintain streamflows during dry weather and thus plays a role in the ecological health of local as well as larger downstream surface-water bodies. 
Simulation of Groundwater Flow in the Aquifer System of the Anacostia River and Surrounding Watersheds, D.C., Md., Va.

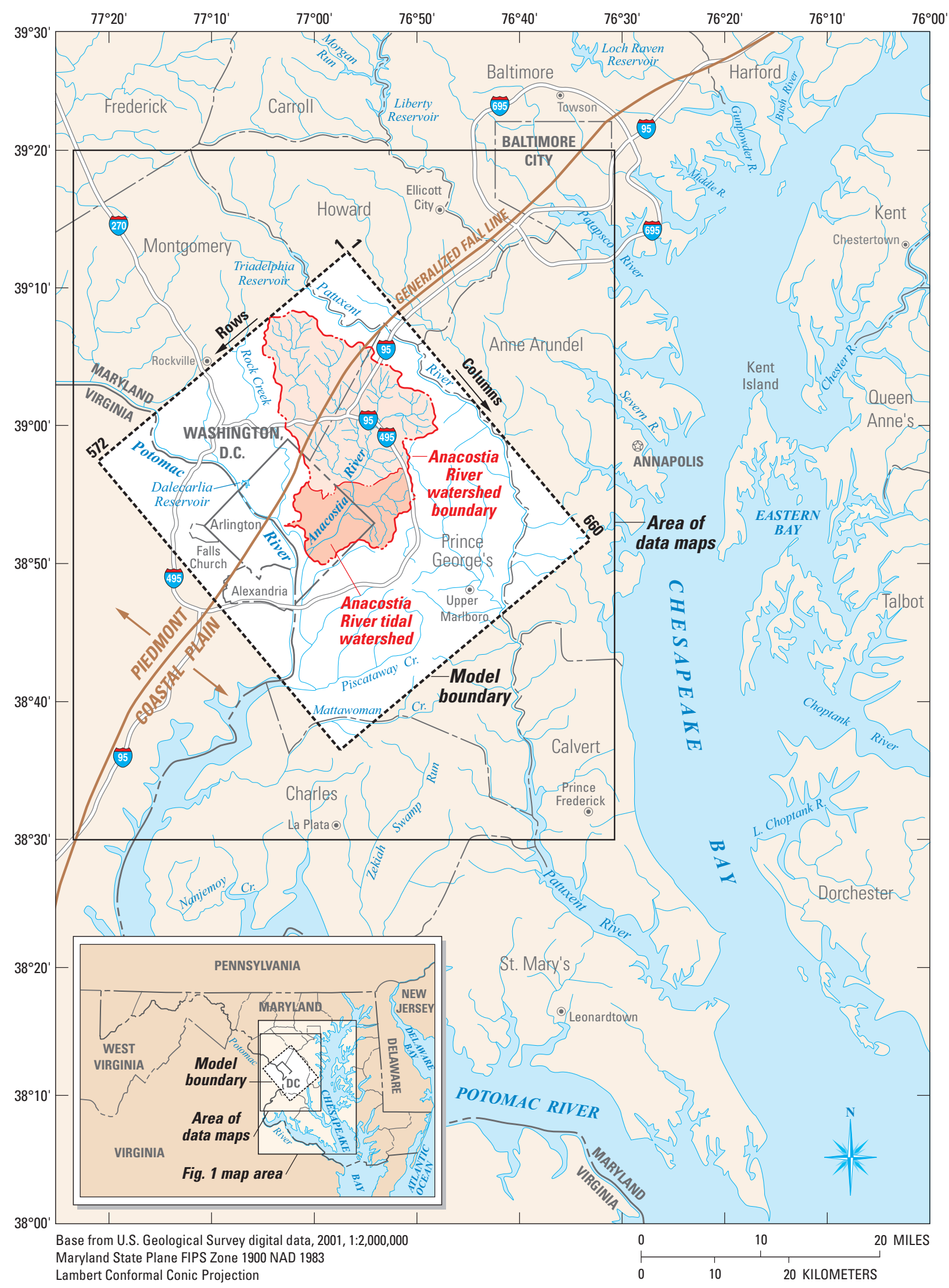

Figure 1. Location of the Anacostia River watershed and model domain. 


\section{Purpose and Scope}

This report documents the design and calibration of a regional, three-dimensional, steady-state, groundwater-flow model of the Anacostia River and surrounding watersheds, including Washington, D.C, parts of Prince George's and Montgomery Counties in Maryland, and northern Virginia. The model uses MODFLOW-NWT (Niswonger and others, 2011), a Newton formulation of MODFLOW-2005 (Harbaugh, 2005). MODFLOW-NWT uses the UpstreamWeighting (UPW) Package, which greatly accelerates rates of convergence for problems involving drying and rewetting nonlinearities typically associated with the solution of the unconfined groundwater-flow equation. Final model calibration was achieved using the objective parameter estimation and sensitivity analysis capabilities of UCODE_2005 (Poeter and others, 2005), incorporating error-based weighting of observations of hydraulic head, or water levels in wells, and stream base-flow observations at four streamgages within the modeled area. The report describes the calibration process and presents calculated sensitivities. Finally, a water budget for several defined zones within Washington D.C., including the tidal part of the Anacostia River, is presented.

\section{Previous Investigations}

Groundwater hydrology and geochemistry within the tidal Anacostia River watershed in Washington, D.C. are affected by both natural and human influences. A comprehensive groundwater resource assessment for the District of Columbia completed in 1993 (Schneider and others, 1993) included a description of local aquifers and their physical and chemical characteristics, as well as recommendations for the development of a groundwater protection program. The assessment was driven by the recognition that pollutants produced by urban land-use activities (including construction practices, leaking underground storage tanks, and application of chemicals) can create immense challenges in protecting groundwater resources, necessitating continuing monitoring and scientific study. The recommendations from that study for a groundwater protection program reinforced the need for expansion of the monitoring network and additional research.

Information obtained from new field work along with interpretations of available subsurface data can provide insight for groundwater investigations in the tidal Anacostia River. The USGS collected cores at several locations in the summer of 2002 and analyzed samples of sediment and groundwater (Miller and Klohe, 2003); the lithology of the wells and cores is described in Tenbus (2003). These cores were relatively shallow (30 to 65 feet, or $\mathrm{ft}$ ) and provide information on the surficial and near-surface materials. More recently, Ator and others (2020) provided cross sections for the tidal Anacostia watershed. The cross sections were interpreted from the 2002 cores and later coring by the USGS in 2005 and 2008. Additional deeper cores (approximately 200 to $400 \mathrm{ft}$ deep), drilled in cooperation with DOEE and the D.C. Water Clean Rivers Project to bedrock, coring by D.C. Water Clean Rivers Project, and other various core logs in conjunction with a surficial geologic map based on Southworth and Denenny (2006) were used in the geologic interpretation.

A three-dimensional groundwater-flow model was developed by Logan (1999) at a sub-regional scale and used to estimate the groundwater flux to the tidal Anacostia River. The model was designed to simulate the behavior of shallow groundwater, not the regional flow system. The modeling effort used existing observations of water levels in the shallow part of the system and water-table maps produced by Matheson and others $(1994,1995)$. Additional water-level observations for the modeling described in this report are summarized in Ator and others (2020).

\section{Hydrogeologic Framework}

Washington, D.C. is situated on both sides of the Fall Line, the boundary between the Piedmont and the Atlantic Coastal Plain Physiographic Provinces (fig. 1). The Anacostia River is a tributary to the tidal Potomac River in central Maryland and Washington, D.C. The head of tide on the Anacostia River is located upstream from the Washington, D.C. boundary. The tidal Anacostia watershed extends over approximately 26 square miles $\left(\mathrm{mi}^{2}\right)$ including most of eastern Washington, D.C., and lies entirely within the Atlantic Coastal Plain Physiographic Province. The watershed is almost exclusively (greater than 80 percent) urban, including mixed residential, commercial, and industrial areas. Urban development over the last 200 years has resulted in considerable hydrologic alteration to the watershed, including dredging of the Anacostia River, filling of tributaries and riparian areas, construction of impervious surfaces, sewers, pipelines, and tunnels, and dewatering for construction purposes (Williams, 1977).

The study area includes the tidal and nontidal watersheds of the Anacostia River and parts of the watersheds of nearby rivers: the Potomac River, Patuxent River, Piscataway Creek, Rock Creek, and others within Washington, D.C., northern Virginia, and Prince George's and Montgomery Counties, Maryland (fig. 1). In the study area, the Piedmont consists of deeply weathered metamorphic and igneous rocks dipping to the southeast at a slope of approximately 125 feet per mile (Darton, 1950), overlapped by an eastward thickening wedge of unconsolidated Coastal Plain sediment. The Coastal Plain consists of layers of sedimentary deposits, including marine and marginal marine sands, silts, and clays, ranging in age from Cretaceous to recent (Vroblesky and Fleck, 1991). Descriptions of the unconsolidated geologic units in Washington, D.C. are available in Southworth and Denenny (2006). 


\section{Surficial Deposits}

Surficial deposits in the study area consist of unconsolidated clays, silts, sands, and gravels that are the product of complex transgressive and regressive marine depositional processes and later reworking by both natural and anthropogenic processes (table 1). In this report, surficial deposits denote materials at or near the land surface, and may include outcrops of Coastal Plain aquifers and confining units. The weathered rocks of the Piedmont are described below. Descriptions and maps of surficial deposits for the active model region in Washington, D.C., Maryland, and Virginia are from Southworth and Denenny (2006) and Dicken and others (2005), and are provided in table 1 and figure 2.
The uppermost geologic units in the study area are the youngest and include coarse upland sediments and more recent alluvial and terrace deposits along modern stream channels. Coarse deposits made up primarily of gravel and sand occur as erosional remnants in relatively isolated uplands (Cooke and others, 1952; Johnston, 1964; Southworth and Denenny, 2006). The Anacostia River Valley and much of downtown Washington, D.C. near the confluence of the Anacostia and Potomac Rivers are underlain by Pleistocene fluvial and estuarine terrace deposits and more recent alluvium (Cooke and others, 1952; Johnston, 1964; Southworth and Denenny, 2006). Terrace deposits include fining-upward sequences of sediment (including gravel, sand, silt, and clay) formed as the ancient river valleys were flooded by rising sea levels. Holocene alluvium (primarily clay, sand, and gravel usually

Table 1. Surficial geologic units and descriptions for the Washington, D.C. area.

[Index, index number as mapped in figure 2; Dicken, Dicken and others, 2005; S\&D, Southworth and Denenny, 2006; Andreasen, Andreasen, Maryland Geological Survey, written commun., 2008; n/a, not applicable]

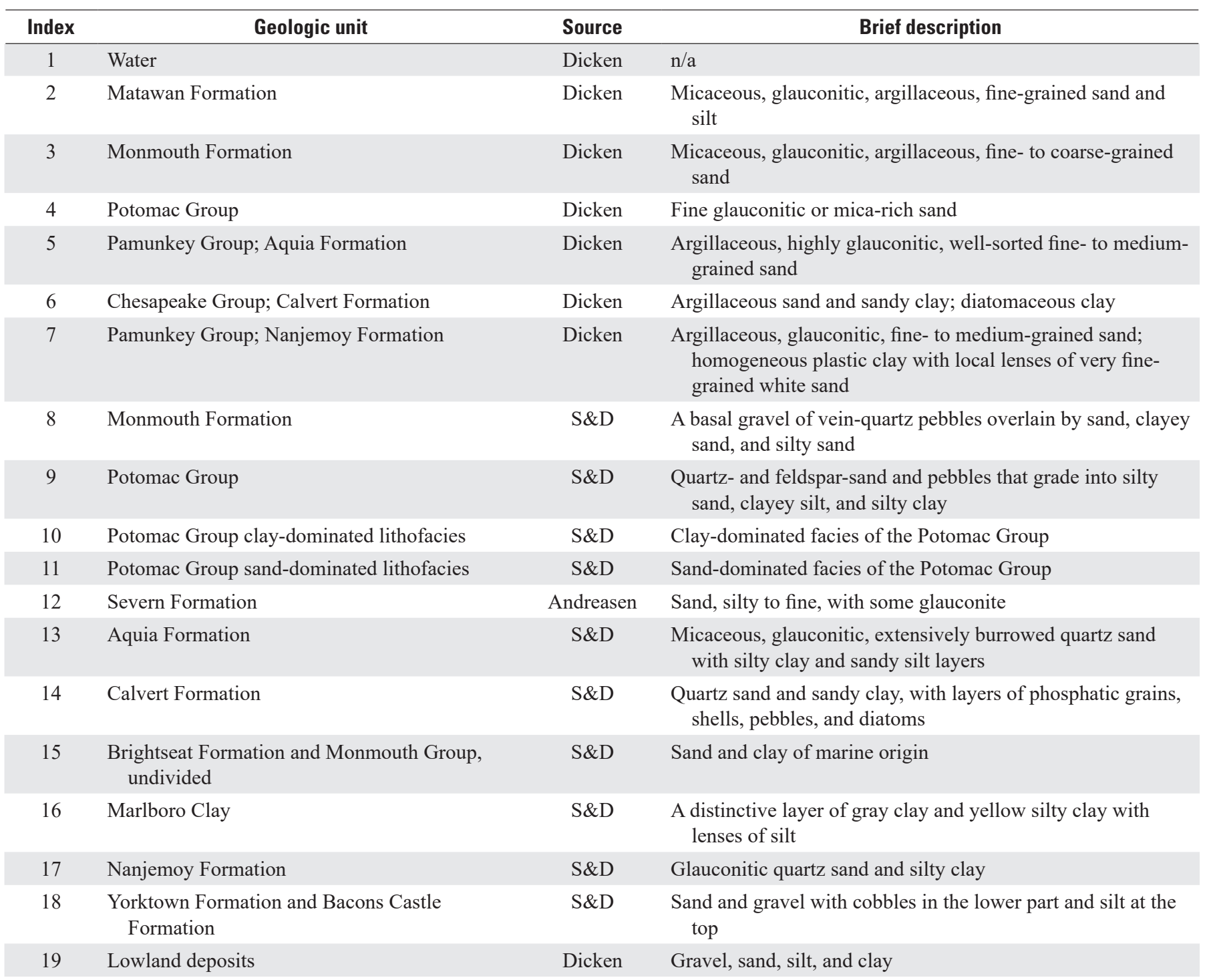


Table 1. Surficial geologic units and descriptions for the Washington, D.C. area.-Continued

[Index, index number as mapped in figure 2; Dicken, Dicken and others, 2005; S\&D, Southworth and Denenny, 2006; Andreasen, Andreasen, Maryland Geological Survey, written commun., 2008; n/a, not applicable]

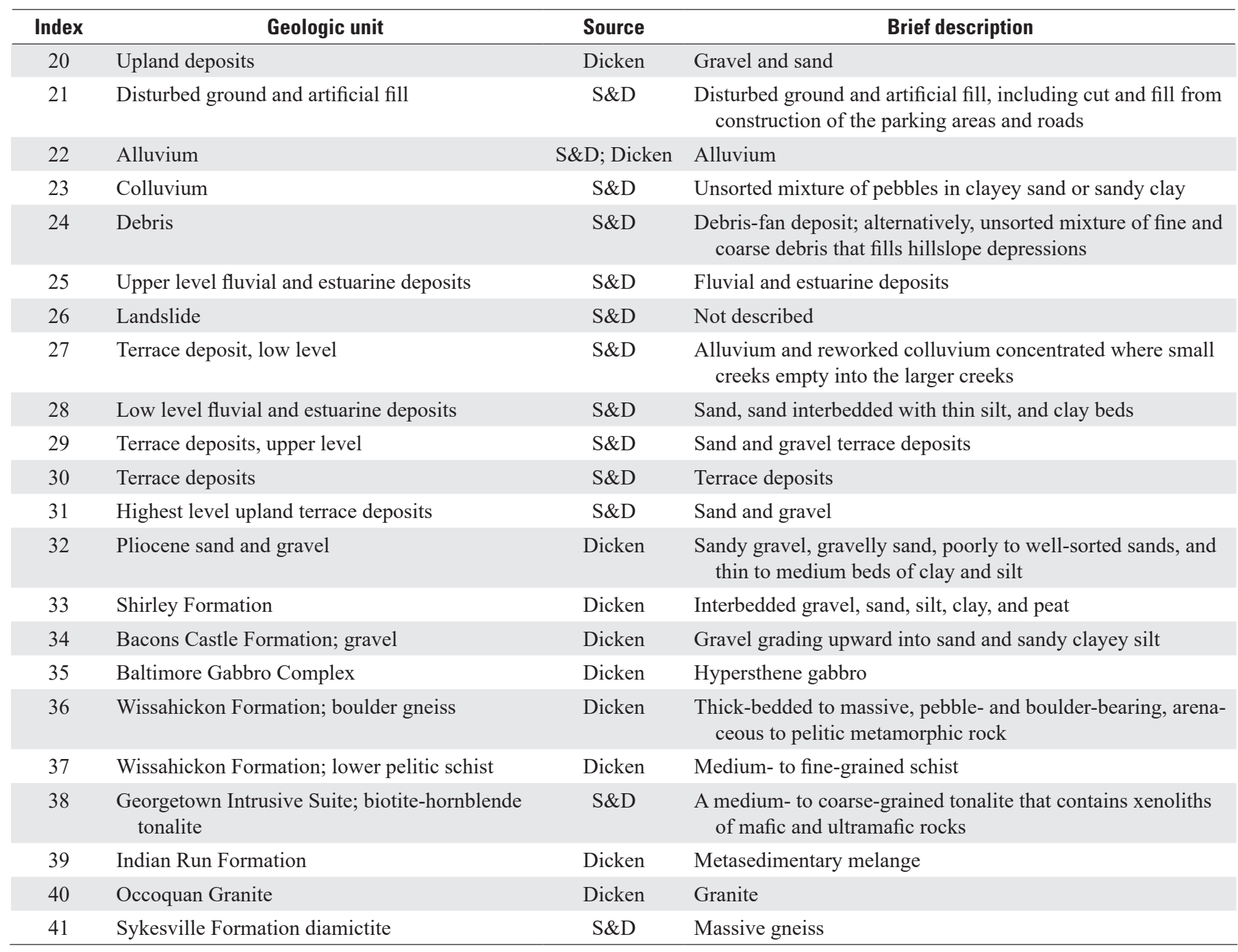

only a few feet thick) occurs beneath the modern Anacostia flood plain and river channel (Johnston, 1964; Southworth and Denenny, 2006).

The modern land surface in the study area reflects anthropogenic influences, as well as modern sea level. Streambed sediments in the Anacostia River in the study area are predominantly fine-grained clay and mud with abundant organic matter, as might be expected in a tidal estuary, although zones of coarser sands and gravels do occur (Velinsky and others, 1994; Washington Metropolitan Area Transit Authority, 1981). In addition, the modern river and its watershed reflect anthropogenic influences typical of urban areas (Behm and others, 2003). Natural sediments are overlain in many areas by artificial fill (Southworth and Denenny, 2006). The river and its streambed and riparian areas, in particular, have been altered by dredging and land reclamation; much of the modern riverfront is underlain by fill overlying buried marsh deposits (Williams, 1977).

\section{Coastal Plain Aquifers and Confining Units}

The major Coastal Plain aquifers and confining units in the study area are (stratigraphically from top to bottom): the Aquia aquifer and underlying confining unit, the Magothy aquifer and adjacent confining units, the upper Patapsco aquifer, the Patapsco confining unit, the lower Patapsco aquifer and underlying Arundel Clay confining unit, and the Patuxent aquifer (Soeder and others, 2007). These units thin and become absent to the northwest within Washington, D.C., and thicken downdip to the southeast. The Lower Cretaceous Potomac Group units (including the lower and upper Patapsco 

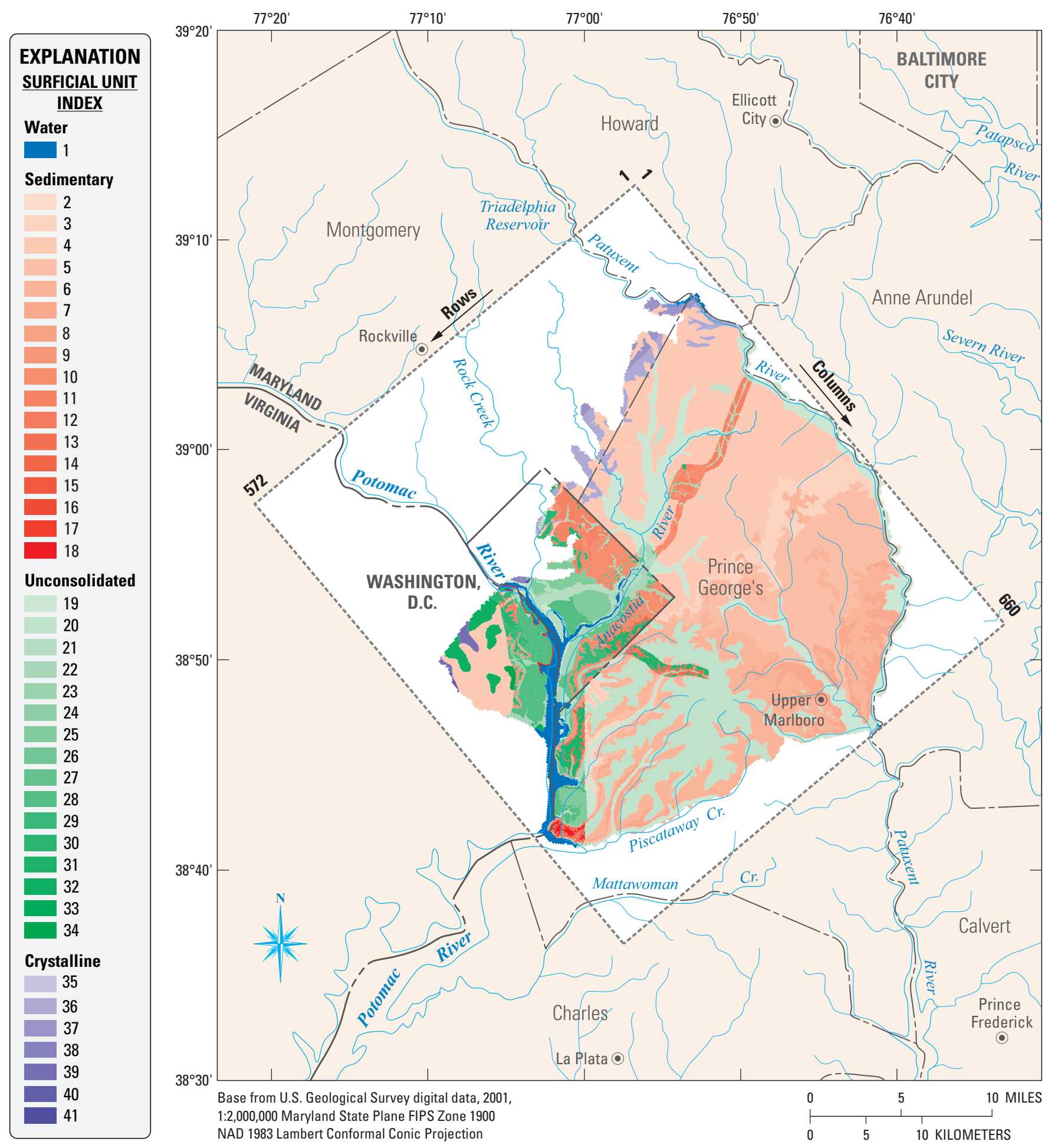

Figure 2. Distribution of surficial geologic units in Washington, D.C., Maryland, and Virginia. (Index numbers refer to descriptions in table 1 [Modified from Dicken and others, 2005; Southworth and Denenny, 2006; David C. Andreasen, Maryland Geological Survey, written commun., 2008]). 
aquifers, the Patapsco confining unit, the Arundel Clay, and the Patuxent aquifer) outcrop or subcrop in Washington, D.C.

The Aquia aquifer consists of fine- to medium-grained, glauconitic quartz sands of the Aquia Formation (Nogan, 1964). The outcrop and recharge area for the Aquia aquifer extends in an irregular band from the Potomac River in western Charles County, through Prince George's County and into eastern Anne Arundel County, where it forms prominent, yellowish-tan bluffs along some of the tributary streams into Chesapeake Bay (Hansen, 1974). The Aquia is an important water-supply aquifer in southern Maryland. The greatest reported well yields in the Aquia aquifer are as high as 0.7 million gallons per day (Mgal/d) in eastern St. Mary's and southern Calvert Counties (Weigle and others, 1970). The Aquia aquifer outcrops and subcrops along the high ridge area in southeast Washington, D.C., near the Maryland and Washington, D.C. boundary (fig. 2).

The Magothy aquifer consists of sandy beds of the Magothy Formation, and in some areas may include sands of the Patapsco Formation (Mack and Mandle, 1977). The lithology consists of unconsolidated light gray to white, fine to medium quartz sand and fine gravel containing pyrite and lignite, with glauconite in the upper part (Hansen, 1972). The Magothy Formation is part of a transgressive sequence present between Lower Cretaceous fluvial-dominated deposits and Tertiary marine-dominated strata (Hansen, 1972). The outcrop and recharge area occurs in a narrow band through the northern end of Prince George's County and across north-central Anne Arundel County (Achmad and Hansen, 2001). Mack (1974) described an upper and lower unit within the Magothy Formation separated by 10 to $20 \mathrm{ft}$ of clay, and noted that the coarse sand layers interbedded with clay result in hydraulic conductivities that are much higher in the horizontal direction than in the vertical direction. The confining beds overlying the Magothy aquifer are made up of several geologic units that may, in places, also function as aquifers (Achmad and Hansen, 2001). These beds consist of the predominantly marine sediments of the Matawan and Monmouth Formations. In Anne Arundel County, the Matawan Formation consists of dark gray and black silty clay that acts as a confining unit on top of the Magothy aquifer (Andreasen, 2002). The Magothy Formation does not outcrop in Washington, D.C.

The upper Patapsco aquifer consists of multiple sand layers and lenses within the upper part of the Patapsco Formation. Similarly, the lower Patapsco aquifer consists of multiple sand layers and lenses within the lower part of the Patapsco Formation. The Patapsco Formation was described by Clark (1897) as colored and variegated clays, which grade into lightercolored sandy clays with interstratified sandy bands of coarser materials. The outcrop and recharge area for the Patapsco Formation runs northeast from the eastern side of the Washington, D.C. area to the southeastern side of Baltimore City, Maryland, through western Prince George's and Anne Arundel Counties (Achmad and Hansen, 2001). Despite the finergrained nature of the sediments, Mack and Achmad (1986) reported that the lower Patapsco aquifer is capable of yielding
0.5 to $2 \mathrm{Mgal} / \mathrm{d}$ from individual wells in most locations where it has been tested in Anne Arundel County. The confining layer separating the lower and upper Patapsco aquifers was described by Mack and Achmad (1986) as unnamed massive beds of clay characterized by low vertical hydraulic conductivity, although some layers within the confining bed are more permeable. The confining layer separating the lower and upper Patapsco aquifers was informally named the Patapsco confining bed by Achmad and Hansen (2001), who described it as multi-colored, massive, clayey beds of low hydraulic conductivity, although they also noted that at some locations, it may be more sandy and less effective as a confining unit.

In Washington, D.C., the lower and upper Patapsco aquifers are not differentiated (Southworth and Denenny, 2006), and the Patapsco Formation is primarily fine-grained sediments with some sandy zones that are not easily correlated over any distance. Because the Patapsco Formation is also difficult to differentiate from the Arundel Clay in the Washington, D.C. area, the Patapsco Formation and Arundel Clay underlying the city are locally identified as the Potomac Group clay-dominated lithofacies (index 10 on fig. 2). The Potomac Group clay-dominated lithofacies outcrops in northeastern Washington, D.C., northwest of the Anacostia River, and in eastern and southeastern Washington, D.C., southeast of the Anacostia River.

The Patuxent aquifer consists of multiple sand layers in the Patuxent Formation characterized by varying thickness and lateral extent. The Patuxent Formation was described by Clark (1897) as a cross-bedded, arkosic sand with layers of relatively pure sand, although some of the arenaceous beds contain clay lumps and sandy clays. Clark stated that the sediments show evidence of shallow-water deposition. The lithology of the Patuxent Formation is described by Glaser (1969) as a medium-grained to coarse-grained sand or pebbly sand and gravel, interbedded with relatively thin, pale-gray clays. The formation is composed of generally finer-grained sands in the upper part, where it is overlain and confined by the low-permeability Arundel Clay. The general lack of silt and clay in the lower part of the Patuxent Formation indicates that the sands were deposited in a relatively high-energy, fluvial and deltaic environment (Glaser, 1969). The Patuxent aquifer is capable of yielding large quantities of water to wells. Well fields in Anne Arundel and Prince George's Counties have produced yields as high as $2 \mathrm{Mgal} / \mathrm{d}$, and yields of 0.5 to $1 \mathrm{Mgal} / \mathrm{d}$ are not uncommon (Mack and Achmad, 1986). The aquifer is relatively thin to the north, and pinches out in the northwestern part of Anne Arundel County (Mack and Achmad, 1986). The recharge area for the Patuxent aquifer is a relatively narrow outcrop band located between the western limit of the overlying Arundel Clay and the pinch-out of the Patuxent against the consolidated rocks of the Piedmont a few miles farther west (Mack and Achmad, 1986). This outcrop band runs parallel to the Fall Line through the northeastern part of Washington, D.C., western Prince George's County, the eastern edges of Montgomery and Howard Counties, and into northwestern Anne Arundel County (Achmad and Hansen, 2001). In 
Washington, D.C., the Patuxent Formation lies unconformably on the Piedmont rocks and outcrops in northeast Washington, D.C. between Rock Creek Park and the outcrop area of the Patapsco/Arundel Formation.

Overlying the Patuxent aquifer is the Arundel Clay, which forms an effective confining bed in most areas by separating the Patuxent aquifer from the overlying lower Patapsco aquifer. Clark (1897) described the Arundel Clay from stream valley outcrops as a series of large and small lenses of carbonaceous, iron-bearing clay, up to $125 \mathrm{ft}$ in thickness. Achmad and Hansen (2001) reported that the Arundel Clay can be 300 to $400 \mathrm{ft}$ thick in Southern Maryland. The Arundel Clay was probably deposited in a low-energy river flood plain and swamp environment (Glaser, 1976). The association of massive clays, lignitic logs, and rooted stumps, occasional dinosaur bones, and the complete absence of marine fossils indicate that the clay was deposited in shallow, backswamp basins maintained by ponded drainage and slow sediment influx (Glaser, 1969). The contact between the top of the Arundel Clay and the overlying Patapsco Formation was described as unconformable (Brenner, 1963).

The Arundel Clay in the tidal Anacostia River Basin beneath Washington, D.C. thins or is absent in places, as indicated by studies of cores (Ator and others, 2020; Tenbus, 2003; Washington Metropolitan Area Transit Authority, 1981). This unit may be of particular importance in determining groundwater-flow rates and flow paths in the tidal Anacostia River watershed. Recent coring revealed particularly thick (greater than $100 \mathrm{ft}$ ) alluvial and estuarine sequences around the lower Anacostia River near its mouth (Ator and others, 2020, fig. 4C). The river may have eroded completely through the Arundel Clay to the underlying Patuxent Formation in this area. Further coring would be necessary to determine the lateral extent of missing clay-dominated lithofacies. Another location where data indicate that the clay-dominated lithofacies is missing is beneath the northwestern bank of the Anacostia River near the South Capitol Street Bridge (Ator and others, 2020; MACTEC Engineering and Consulting, Inc., 2005). Data from this bridge crossing generally indicate the existence of the clay-dominated lithofacies from approximately $-25 \mathrm{ft}$ down to greater than $-75 \mathrm{ft}$ relative to mean sea level (msl) on the southeastern bank of the Anacostia River, indicating that the clay-dominated lithofacies thins and pinches out near the southeastern bank of the Anacostia River. In the center of the channel, a clay-dominated lithofacies approximately 10 to $40 \mathrm{ft}$ thick exists between -90 and $-120 \mathrm{ft}$ relative to $\mathrm{msl}$. The cross section also indicates that from the center of the channel to the northwest bank, the lithology is primarily clayey sand, indicating that the clay-dominated lithofacies is missing beneath part of the Anacostia River. However, borings in the northwest part of the cross section are fairly shallow ( 50 to $75 \mathrm{ft}$ below land surface), limiting the interpretation of the presence or absence of the clay-dominated lithofacies. Because of the highly variable depositional environment that produced the Potomac Group, as well as subsequent reworking of the sediments in complex alluvial and estuarine erosional and depositional environments, additional data would be necessary to determine the extent and location of areas where the clay-dominated lithofacies is not present. In such areas, the sand-dominated lithofacies would be in direct connection with shallower sand deposits (terrace or alluvial deposits).

\section{Piedmont}

The Piedmont has three distinct geologic areas or provinces - carbonate, siliciclastic, and igneous and metamorphic crystalline rocks (Fleming and others, 2012; Swain and others, 2004). In the study area, including parts of Washington, D.C., Montgomery County in Maryland, and northern Virginia, the predominant rock type is igneous and metamorphic crystalline rocks (the gneiss-schist hydrogeologic terrane described by Swain and others, 2004) of the Piedmont Uplands (described in Fleming and others, 2012). The igneous and metamorphic province includes terranes accreted during plate tectonic activity. The crystalline rocks are generally covered by saprolite. Permeability tends to be somewhat higher in the upper part of the modern soils that have developed near the top of the saprolite, where clay has been eluviated, as well as at lower depths, where the clay has been transported (Fleming and others, 2012). The highest permeabilities are typically found at the saprolite/fresh-rock interface or transition zone (Harned and Daniel, 1992). Saprolite thickness and other properties vary according to rock type and topographic position. Within the competent bedrock, groundwater flow is dominated by secondary porosity associated with fractures and joints.

\section{Groundwater-Flow-Model Development}

A preliminary groundwater-flow model was developed in 2010-11 for the model domain shown in figure 1 using MODFLOW-2000 (Harbaugh and others, 2000). The model grid was relatively coarse (500 by 500 square feet or $\mathrm{ft}^{2}$ cells), did not account for true layer geometry, and was calibrated manually. This preliminary model did provide some necessary spatial data, including model extent, boundaries, and surface features that were used in the final model described in this report. It also provided initial property values from the manual calibration that were used with the literature values to objectively estimate optimal values for the final model.

The groundwater-flow model described in this report uses MODFLOW-NWT (Niswonger and others, 2011), a Newton formulation of MODFLOW-2005 that is intended for solving problems involving nonlinearities of the unconfined groundwater-flow equation caused by drying and rewetting. MODFLOW-NWT solves the groundwater-flow equation over a grid of cells using the finite-difference method. The program UCODE_2005 (Poeter and Hill, 1998, 1999; Poeter 
and others, 2005) and supporting codes were used to perform sensitivity analysis, calibration, prediction, and uncertainty analysis, following procedures described in Hill and Tiedeman (2007). All necessary codes were compiled for Mac OS X, and simulations were carried out on a multi-processor Apple Xserve machine, using the parallel-processing capabilities of UCODE_2005 (Poeter and others, 2005).

The following sections describe the conceptual model of the flow system and the procedures and spatial data used for constructing the groundwater-flow model, including spatial discretization, layering, boundary conditions, and stresses (drains, wells). The model simulates steady-state three-dimensional groundwater flow in the Anacostia River and surrounding watersheds. The model domain extends outside of the Anacostia River watershed to better incorporate natural boundaries and simultaneously minimize the impact of any arbitrary boundary conditions that may have been imposed. Therefore, out of necessity, the model is designed to be regional in extent. It includes all of Washington, D.C. and simulates conditions in both the Piedmont and Coastal Plain Physiographic Provinces.

\section{Conceptual Model}

The conceptual model describes the geometry of the system and, qualitatively, the sources and sinks of water in the system. It synthesizes what is known about the system, including the hydrogeologic framework, recharge conditions, hydraulic properties, and discharge conditions (including withdrawal rates). This conceptual model forms the basis for the construction of the quantitative numerical groundwaterflow model.

The model encompasses a layered system representing the wedge of Coastal Plain sediments beginning at the Fall Line and extending and thickening to the southeast. These sediments lie directly on top of weathered and unweathered crystalline rocks of the Piedmont (fig. 3). The Piedmont rocks are divided into two layers - an upper layer representing the weathered crystalline rocks (soils and saprolite), and a deeper layer of fractured unweathered rocks. Where Coastal Plain materials are absent, these two Piedmont layers are present at the land surface. Sedimentary aquifer layers in the model include the surficial unconfined (water-table) aquifer and the Aquia aquifer, the underlying confining unit and Magothy aquifer (combined), the upper Patapsco aquifer, the Patapsco confining unit, the lower Patapsco aquifer and Arundel Clay (combined), and the Patuxent aquifer. The extent of each subsurface unit of Coastal Plain sediments is dependent on where it terminates updip. The outcrop areas are indicated schematically in figure 3 , which also shows how hydraulic conductivities of model layers are adjusted where the sedimentary unit is absent to allow for recharge to lower units.

Recharge to the water-table aquifer occurs as direct percolation of infiltrating precipitation. Recharge occurs at the water table, which is located in layer 1 where sediments of the Coastal Plain occur, and in layer 8 where Piedmont materials outcrop above the Fall Line. Recharge is spatially variable and is dependent on a number of land-surface and subsurface characteristics, including the hydraulic conductivity of surficial materials and the extent of impervious area. Evapotranspiration depends on similar properties and also on depth to the water table. Net recharge is the difference between recharge and evapotranspiration. Therefore, net recharge for this study is conceptualized as occurring predominantly in topographically elevated areas where the water table may be tens of feet deep (and where losses due to evapotranspiration are therefore minimized), and less so in lowlands where the water table is at or near land surface. This allows for a reasonable depiction of groundwater recharge and discharge areas based on the topography of the water table (Tóth, 1962, 1963).

Most of the recharge probably discharges to nearby streams and rivers, including tidal rivers. These local flow systems likely represent the bulk of the groundwater flow in the system, especially in the Piedmont, which doesn't have deeper aquifers. Some recharge to the deeper confined aquifers of the Coastal Plain occurs mainly in the outcrop areas where the aquifers are considered effectively unconfined, although recharge to the confined aquifers may also occur where vertical hydraulic gradients favor downward groundwater flow across confining units.

Constant-head boundaries representing surface-water bodies may be either sources or sinks of water to the model. As the model does not extend to the Atlantic Ocean, the downdip margins of the model domain are represented by no-flow or specified head boundaries. Groundwater withdrawals from wells are a major stress on the system, and hydraulic gradients in aquifers near large pumping centers may be reversed, relative to pre-pumping conditions, in some areas (Soeder and others, 2007).

\section{Model Design}

The focus of the model in this study is to quantify regional groundwater flow in the Anacostia River and surrounding watersheds. Although future uses of the model may include refinement to quantify flow paths or traveltimes within the tidal Anacostia River watershed, especially in Washington, D.C., a larger area was modeled to avoid problems associated with specifying arbitrary boundaries and to provide a model that can account for a variety of hydrogeologic elements, including weathered and unweathered rocks of the Piedmont that underlie the Coastal Plain sediments, the southeastwarddipping sediments of the Coastal Plain, and the detailed surficial geologic features that have been mapped in Washington, D.C. A steady-state flow simulation was deemed sufficient for the regional groundwater-flow model.

The design of the groundwater-flow model includes horizontal and vertical discretization of the subsurface representing the aquifer and confining unit layers in the Coastal Plain and the weathered and unweathered bedrock layers in the Piedmont, specification of boundary conditions, estimation 


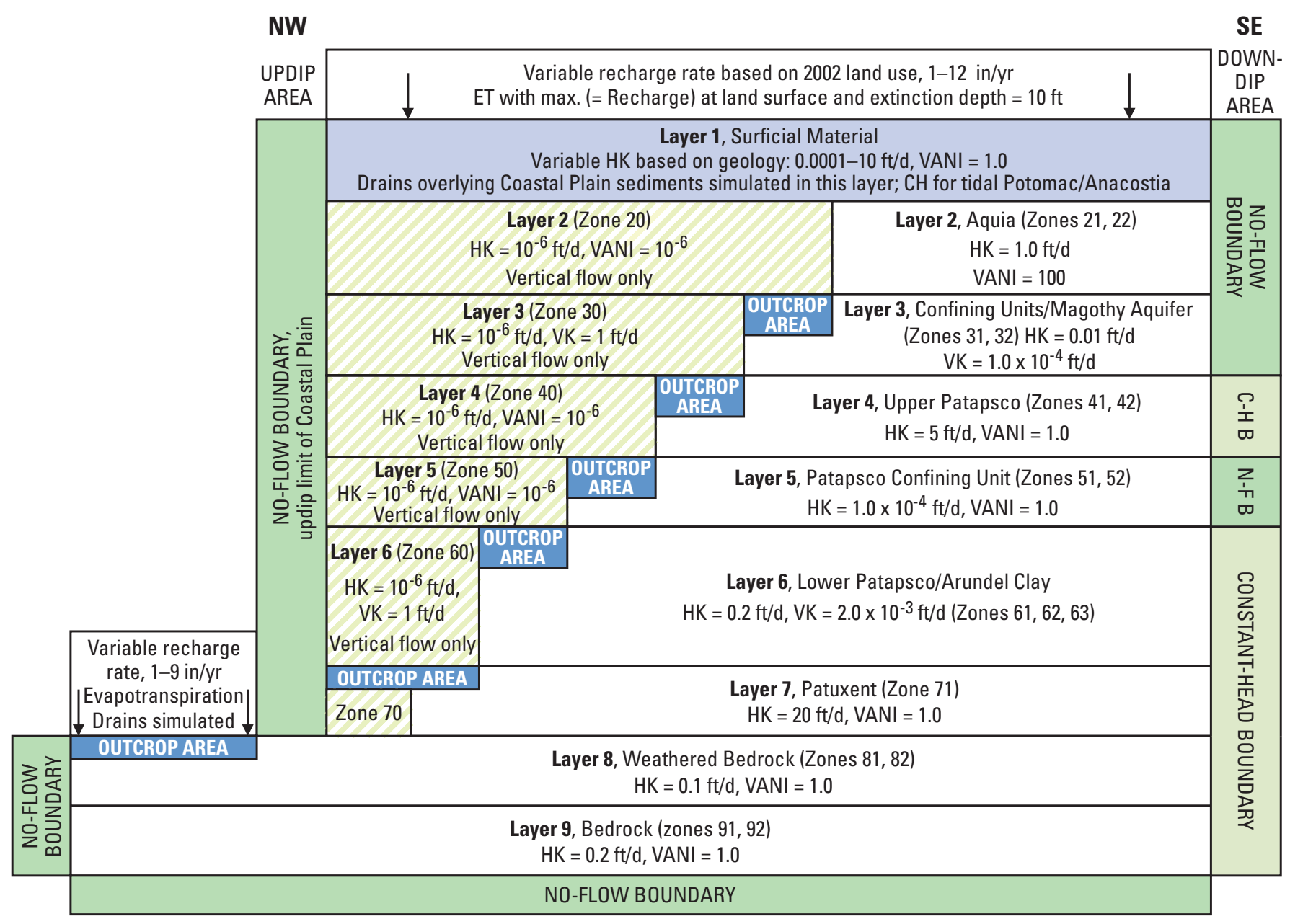

[HK, horizontal hydraulic conductivity; VK, vertical hydraulic conductivity; VANI, horizontal to vertical hydraulic conductivity; $\mathrm{CH}$, constant head; C-H B, constant-head boundary; N-F B, no-flow boundary; ft, feet; ft/d, feet per day; in/yr, inches per year]

Figure 3. Conceptual model of the groundwater-flow system in the Anacostia River and surrounding watersheds, showing schematic layering, location of boundary conditions, zone designations, and initial model hydraulic and other property values. [The vertical schematic section is approximately northwest to southeast through Washington, D.C. and the tidal Anacostia River.]

of initial hydraulic properties for the layers, such as hydraulic conductivity, and definition of the locations of stream reaches and tidal waters. The model also includes an estimate of net recharge, or that portion of infiltrating precipitation that recharges the groundwater system after evapotranspiration, and does not explicitly simulate processes occurring in the unsaturated zone. These elements are sufficient to define the steady-state groundwater-flow system beneath the Anacostia River and adjacent watersheds.

\section{Model Grid}

The model boundary (fig. 1) encompasses approximately $846 \mathrm{mi}^{2}(27.08$ by $31.25 \mathrm{mi})$, of which approximately 65 percent $\left(550 \mathrm{mi}^{2}\right)$ is included in the active flow domain. The origin of the rectangular model boundary is located at $1,326,999 \mathrm{ft}$ east and 565,167 ft north in the Maryland State
Plane Coordinate System based on the datum, and is rotated 310 degrees. The regular grid used to discretize the rectangular model area consists of 572 rows and 660 columns of $62,500 \mathrm{ft}^{2}$ ( 250 by $250 \mathrm{ft}$ ) cells. The model is divided vertically into nine layers.

The updip limit of the Coastal Plain model (layers 1 through 7) is a no-flow boundary where the sediments pinch out, and is based on the extent of the Patuxent aquifer system defined by Vroblesky and Fleck (1991). This boundary has been somewhat modified by deviations based on surficial mapping of unconsolidated sediments (fig. 4). Layers 1 (fig. 4), 2 (fig. 5), and 3 (fig. 6) extend laterally and downdip to a discharge area, defined as either a river or as a no-flow boundary along a watershed divide. Layers 1, 2, and 3 extend to the main stem of the Patuxent River that traverses the study area to the east and to the main stem of Charles Branch, Dower House Pond Branch, and Piscataway Creek to the south. To the west, layers 1, 2, and 3 extend to a segment of the main 
stem of the Potomac River that traverses the study area and to Holmes Run in Virginia. Layers 4 through 9 (figs. 7 through 12) share part of this extent with layers 1, 2, and 3 (Patuxent and Potomac Rivers, Holmes Run), but extend downdip to the limit of the model domain. Piedmont and bedrock layers ( 8 and 9) extend northwest, beyond the extent of layers 1 through 7, to the main stem of Pimmit Run and Little Falls Branch in the west, and to the watershed divide located north of the Anacostia River and Rock Creek.

\section{Layering and Zonation}

A major goal of the groundwater-flow model design was to incorporate true layer geometry of the lithofacies as model layers. This would facilitate model visualization and analysis by georeferencing all cells and cell nodes, implicitly account for changes in the thickness of lithofacies across the model area, and facilitate model parameterization by allowing direct use of hydraulic conductivity rather than transmissivity (the product of hydraulic conductivity and unit thickness). A newly released hydrogeologic framework for the Coastal Plain units was available (Andreasen and others, 2013) in a geographic information system (GIS; referred to as the Coastal Plain Aquifer Information System, or AIS) that could be used to accomplish this goal. In addition to the elevations of both tops and bottoms of aquifer and confining unit surfaces, the new framework also provides information on the extent of the aquifer and other units and the location of their subcrops and outcrops. The areal extent of subcrops and outcrops was used to delineate model zones along lateral dimensions of the model.

Layer elevations in the AIS are in the form of rasters. The $\mathrm{x}, \mathrm{y}$ locations of all nodes at cell centers were used to query the rasters to determine the elevations of all AIS layers beneath a node. This was accomplished in a GIS to produce a new set of features representing the sampled layer elevations. The particular AIS layers and surfaces used for each model layer are shown in table 2. A Python script was created to automatically produce the model layer elevations, beginning with the top of layer 1 and working downward. The process was as follows (table 2):

1. The top of layer 1 was equal to the land-surface elevation, and was sampled for each node from available 30-meter (m) resolution Digital Elevation Model (DEM) data.

2. The bottom of layer 1 was calculated so that the thickness of layer 1 varied smoothly between $50 \mathrm{ft}$ (at elevations less than $100 \mathrm{ft}$ ) and $100 \mathrm{ft}$ (when the elevation of the land surface was greater than $200 \mathrm{ft}$ ).

3. The bottoms of layers 2 through 7 were determined from the hydrogeologic framework in the AIS.

4. Because layers 8 and 9 were not included in the AIS, they were assigned a constant thickness of $50 \mathrm{ft}$ and
$150 \mathrm{ft}$, respectively, to estimate their bottom elevations. Investigators, such as Lewis-Brown and Jacobsen (1995), determined that the most productive waterbearing fractures are within $150 \mathrm{ft}$ of land surface.

Layer thickness could not be less than or equal to zero. A calculated layer thickness of less than $0.1 \mathrm{ft}$ at a node, based on the top and bottom elevations, indicated that the layer had pinched out. The elevation was then set so that the thickness would be equal to $0.1 \mathrm{ft}$. These cells were then assigned properties and a zone number that indicated that, although actively modeled, they were physically absent but could allow recharge to pass through to lower layers.

The locations of pinchouts and subcrop and outcrop areas available in the AIS and from the mathematical exercise of determining cell geometry provided the basis for model layer zonation. Zonation was adopted to (1) provide the possibility for zoning model parameters, (2) to allow for the possibility of using tools such as zonebudget (Harbaugh, 1990) to calculate refined water budgets, and (3) to provide an additional GIS feature that could be useful in selecting parts of the model for analysis or visualization. Model zones are shown in figures 4 through 12; zone numbers consist of a first digit that indicates the layer and a second digit indicating the nature of the cells in that zone (recharge, subcrop, outcrop). Layer 1 has only one zone (zone 11); layers 8 and 9 have two zones each, indicating the Piedmont (zones 81 and 91) and sub-Coastal Plain (zones 82 and 92) parts of the layers. Layers 2 through 7 have two or more zones. Zones that have a number ending in zero denote where recharge is allowed to pass through to layers below; the cells in those zones have a thickness of $0.1 \mathrm{ft}$ and properties that allow rapid vertical transmission of water (see fig. 3). Characteristics of the other zones are summarized in table 3 .

\section{Boundary Conditions}

Simulation of a groundwater-flow system requires specification of appropriate boundary conditions (Reilly, 2001). Two types of boundaries are applied in the model - no-flow and constant-head. Streams, drains, and withdrawals may also be considered boundaries, however, they are described below in the section on Model Stresses. For this study, the model domain was extended beyond the Anacostia River watershed in Washington, D.C. to provide a regional simulation and to avoid problems associated with arbitrary specification of boundaries. The model extent for each layer where natural noflow boundaries occur was described earlier - the updip limit of model layers 1 through 7 is a no-flow boundary where the sediments pinch out. Layers 1, 2, and 3 extend laterally and downdip to a discharge area, a river, or a no-flow boundary corresponding to a watershed divide. Layers 1, 2, and 3 extend to the main stem of the Patuxent River that traverses the study area to the east and to Piscataway Creek to the south. To the west, layers 1,2, and 3 extend to a segment of the main stem of the Potomac River that traverses the study area and to Holmes Run in Virginia. Layers 4 through 9 share part of this 


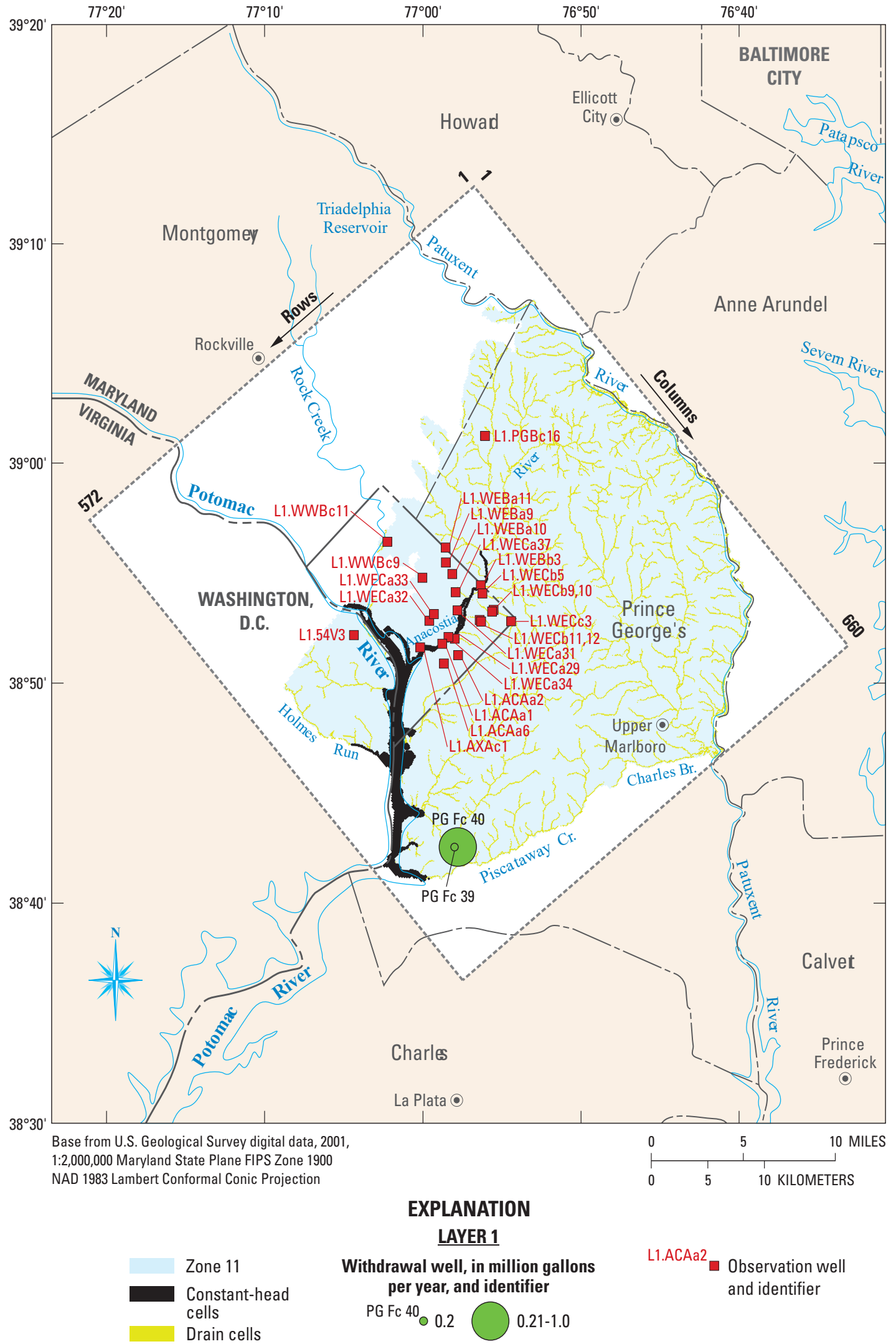

Figure 4. Layer extent and features, model layer 1 (surficial aquifer). 


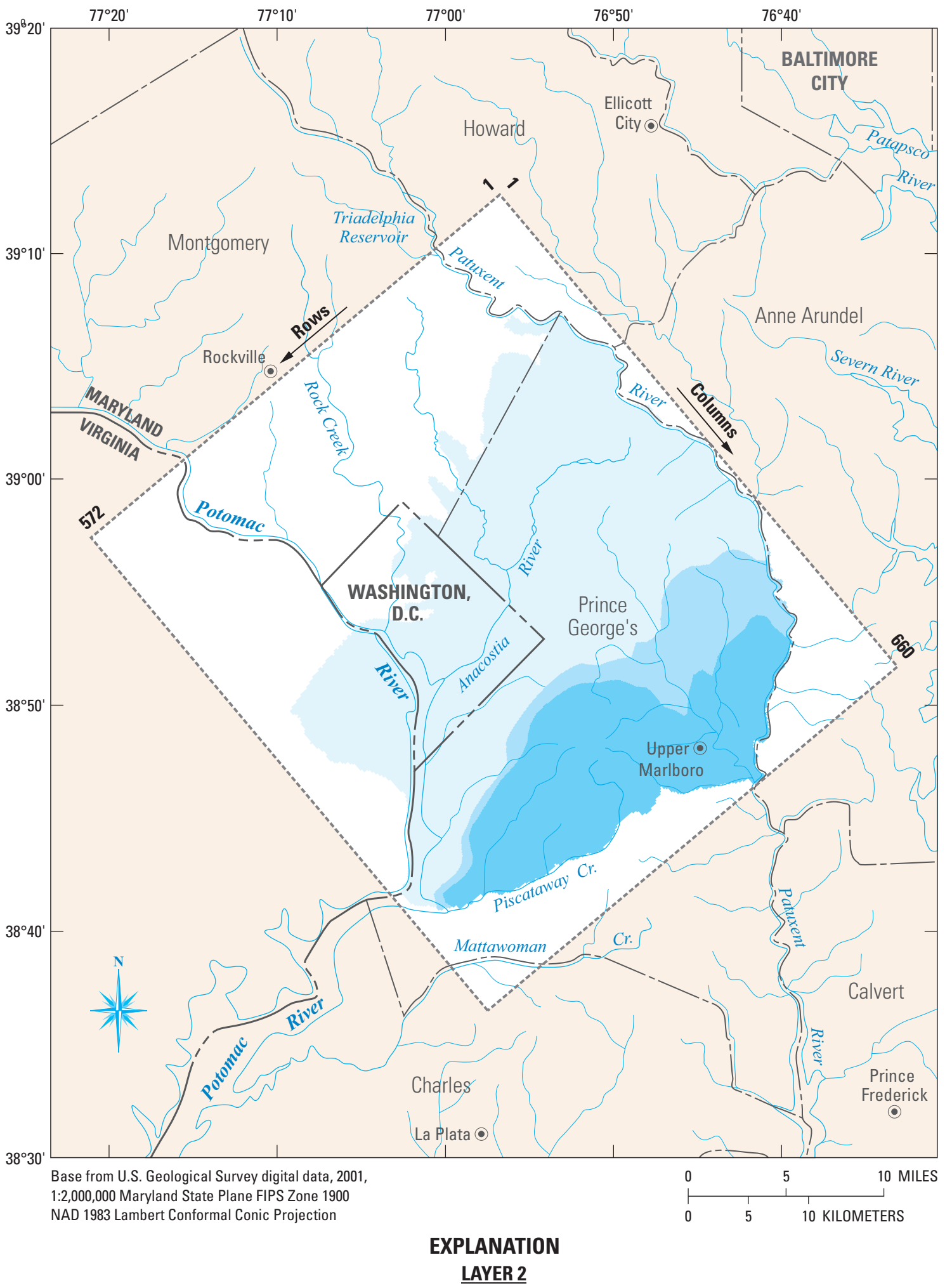

Zone 20

Zone 21

Zone 22

Figure 5. Layer extent and features, model layer 2 (Aquia aquifer). 


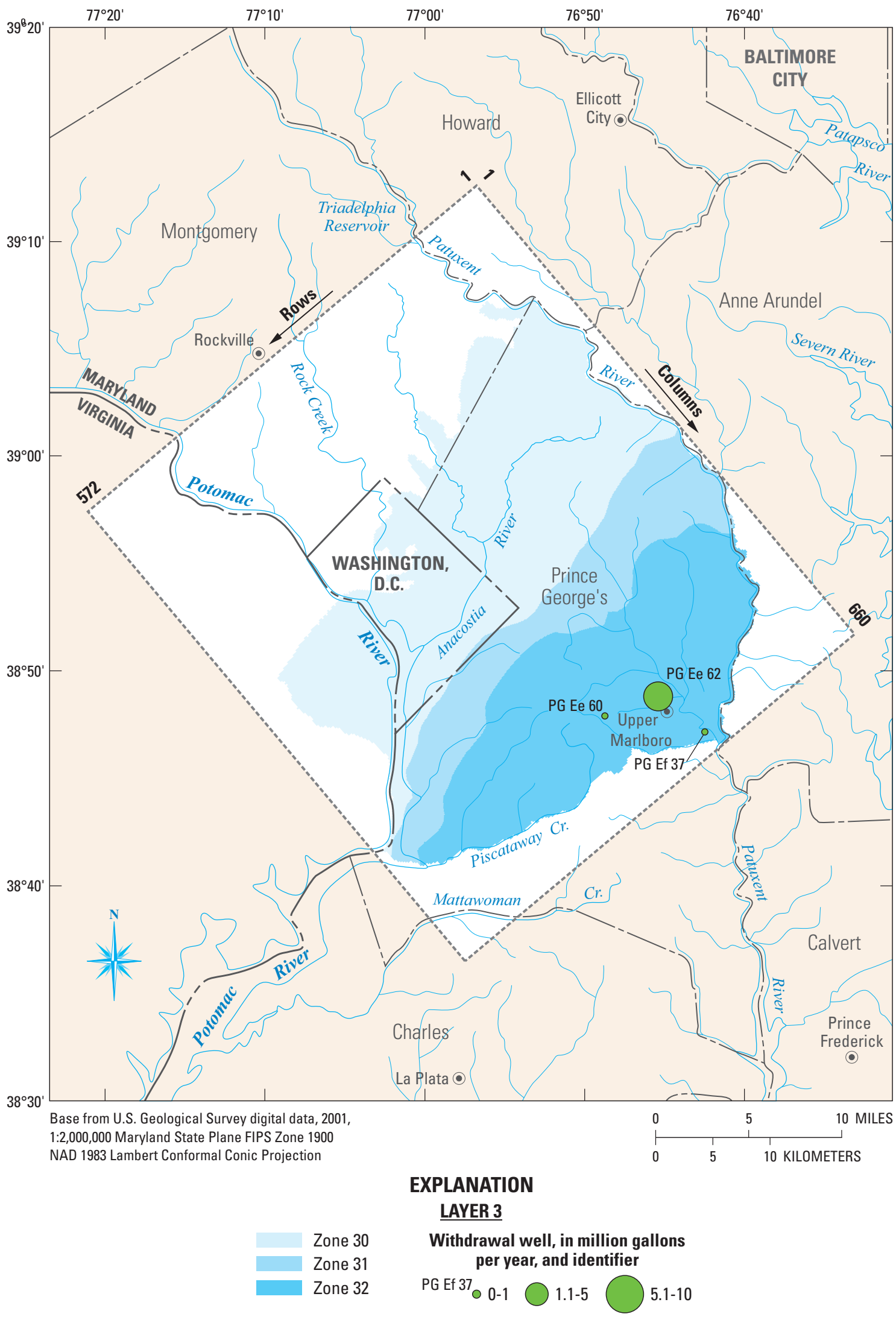

Figure 6. Layer extent and features, model layer 3 (confining unit/Magothy aquifer). 


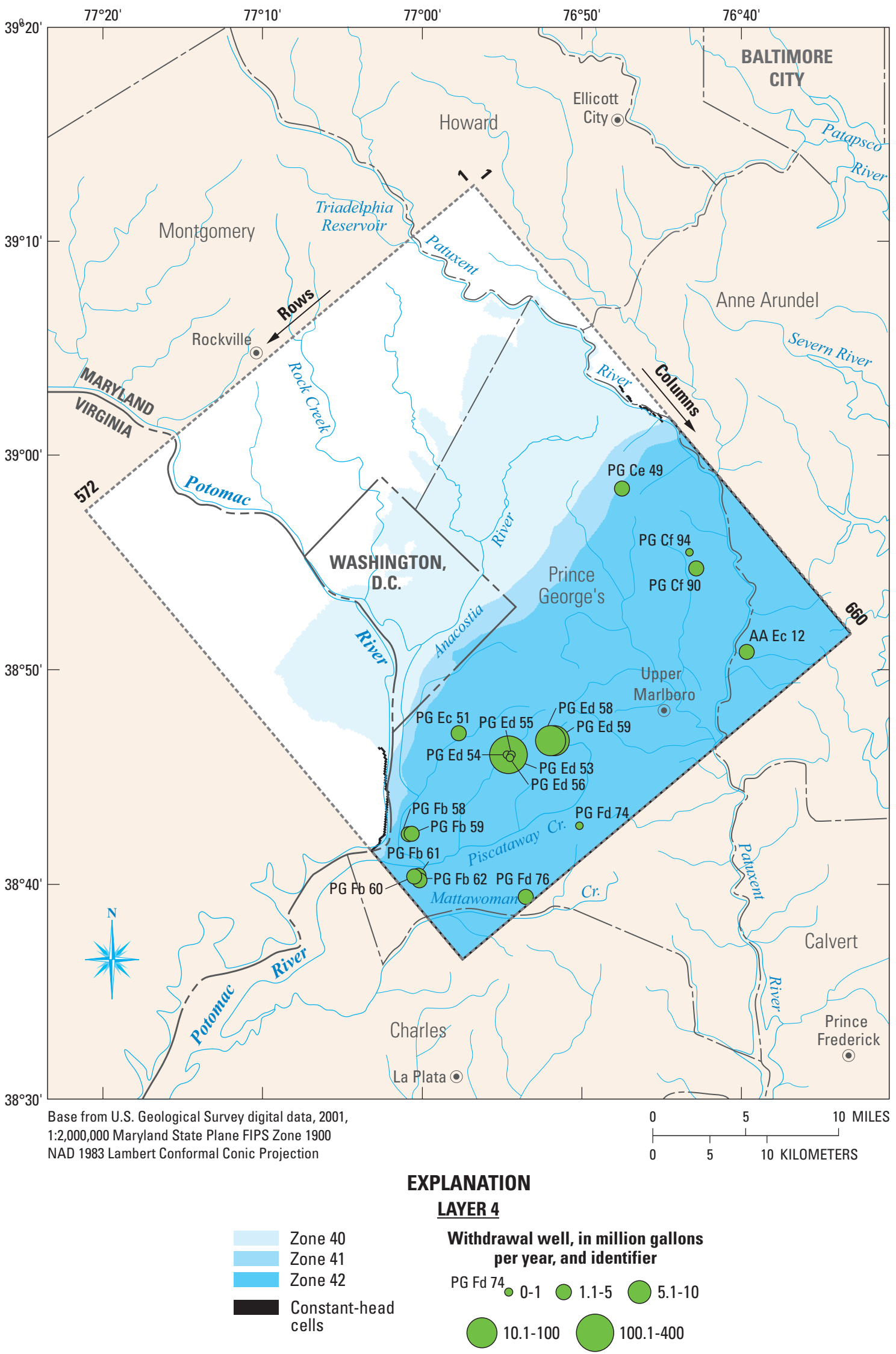

Figure 7. Layer extent and features, model layer 4 (upper Patapsco aquifer). 


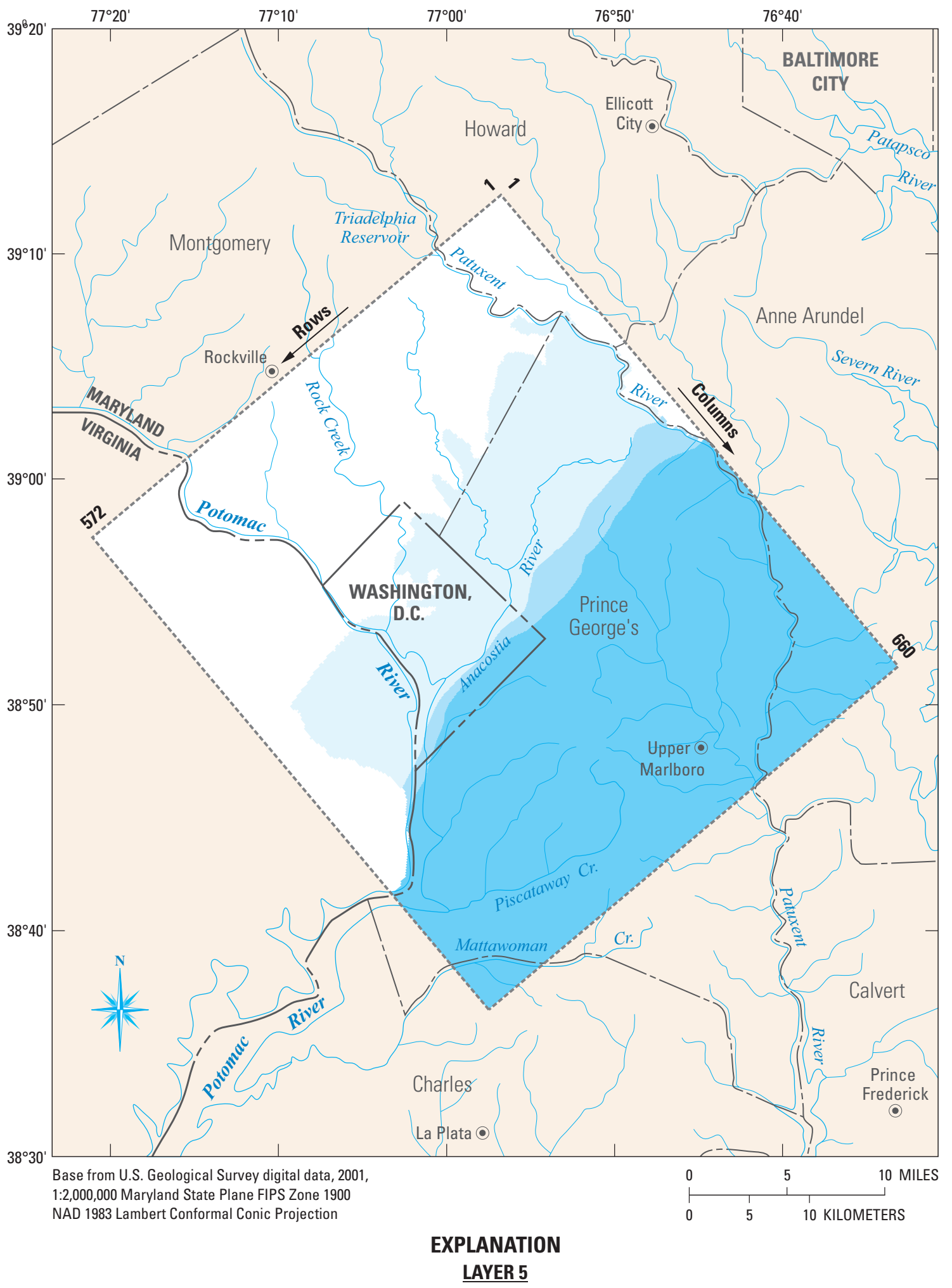

Zone 50

Zone 51

Zone 52

Figure 8. Layer extent and features, model layer 5 (Patapsco confining unit). 


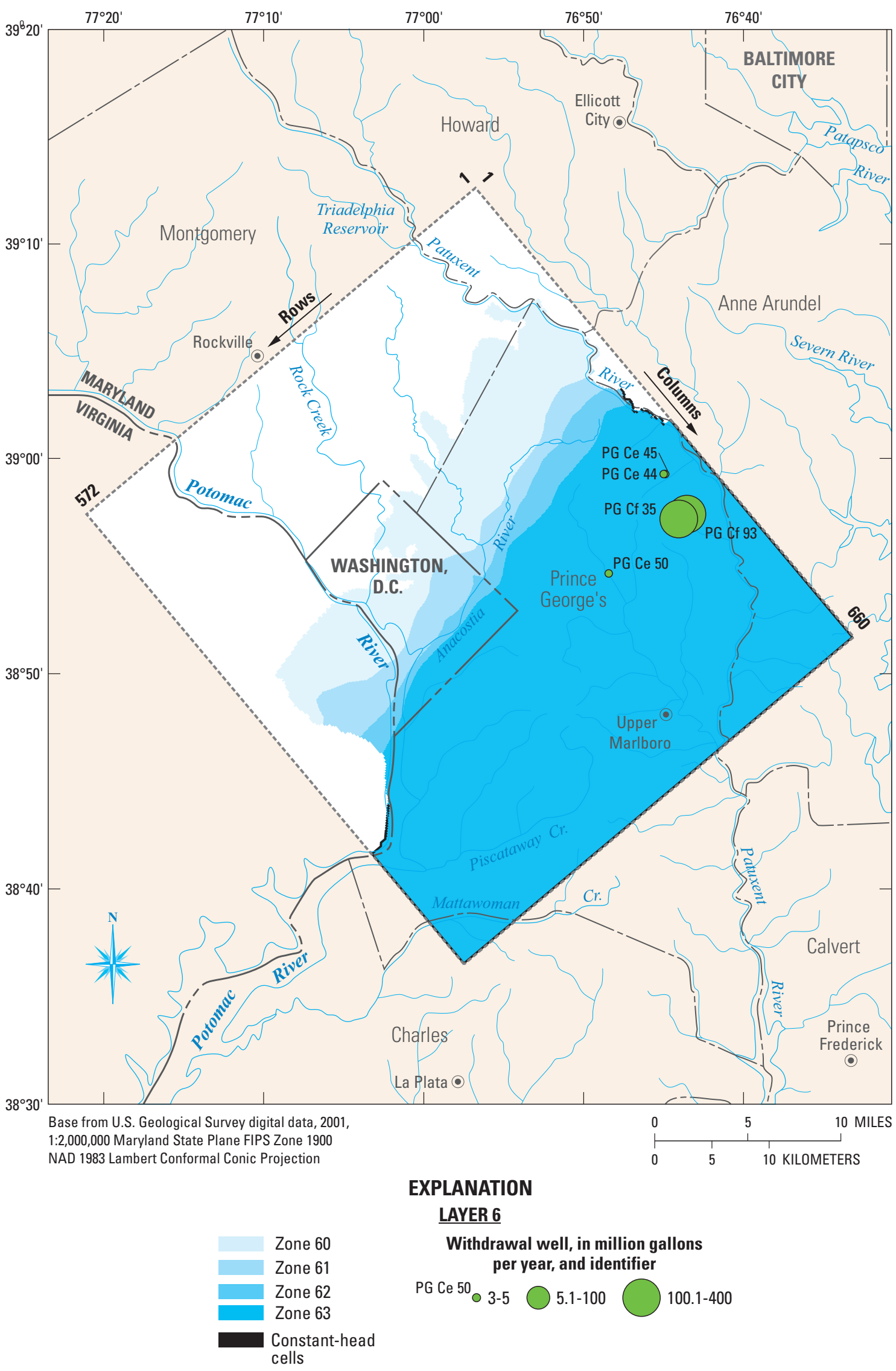

Figure 9. Layer extent and features, model layer 6 (lower Patapsco aquifer/Arundel Clay). 


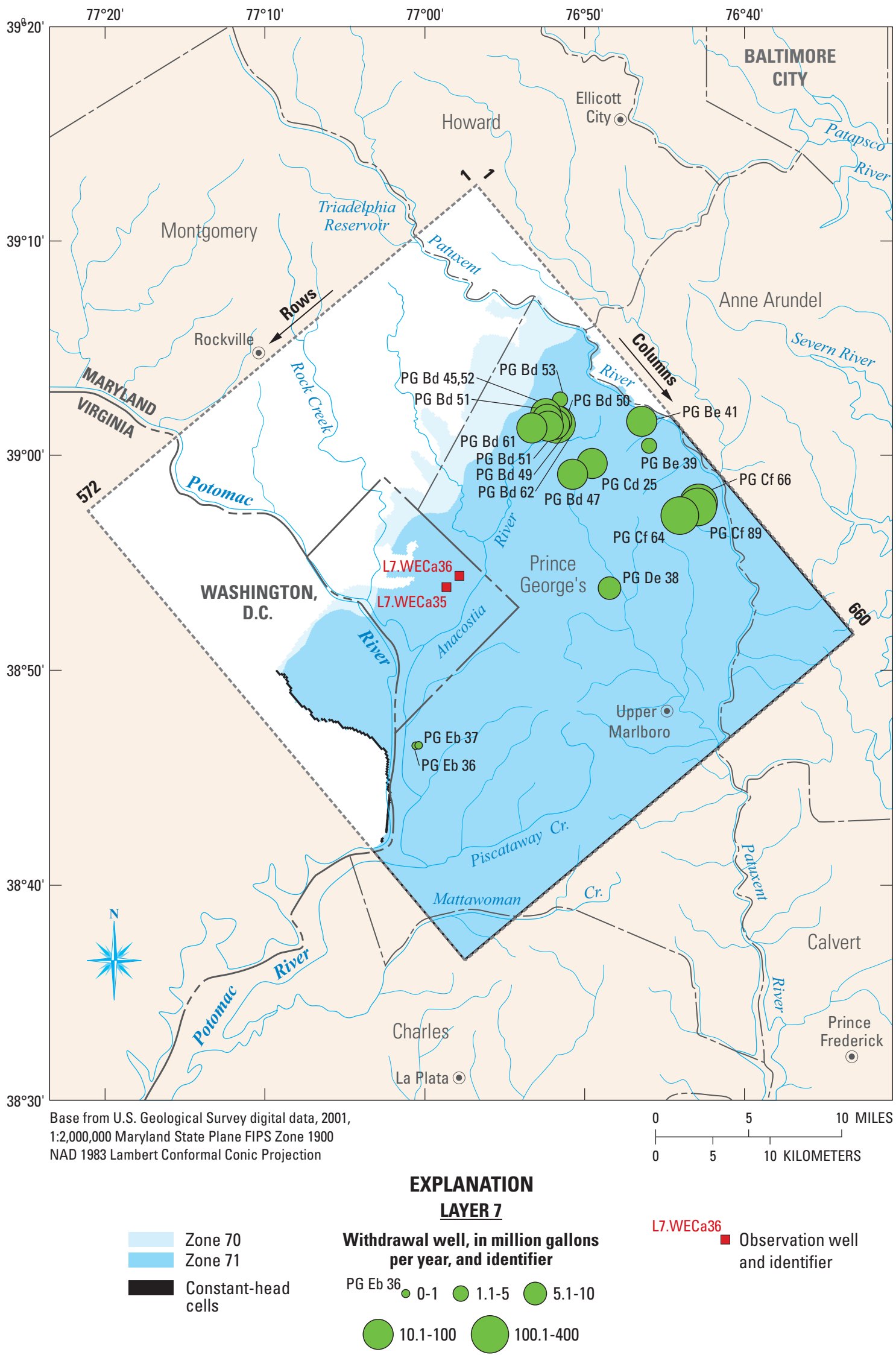

Figure 10. Layer extent and features, model layer 7 (Patuxent aquifer). 


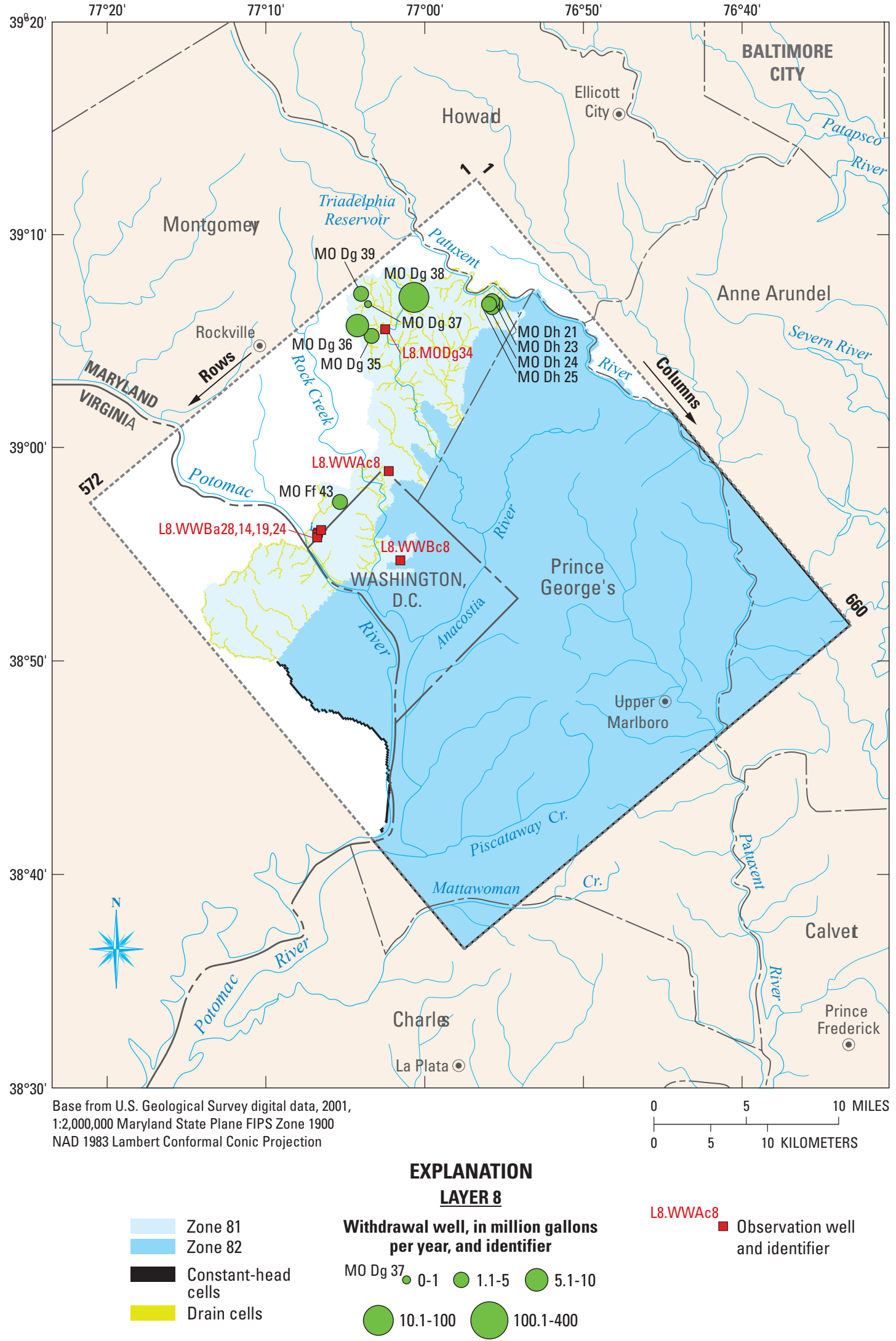

Figure 11. Layer extent and features, model layer 8 (weathered Piedmont bedrock). 


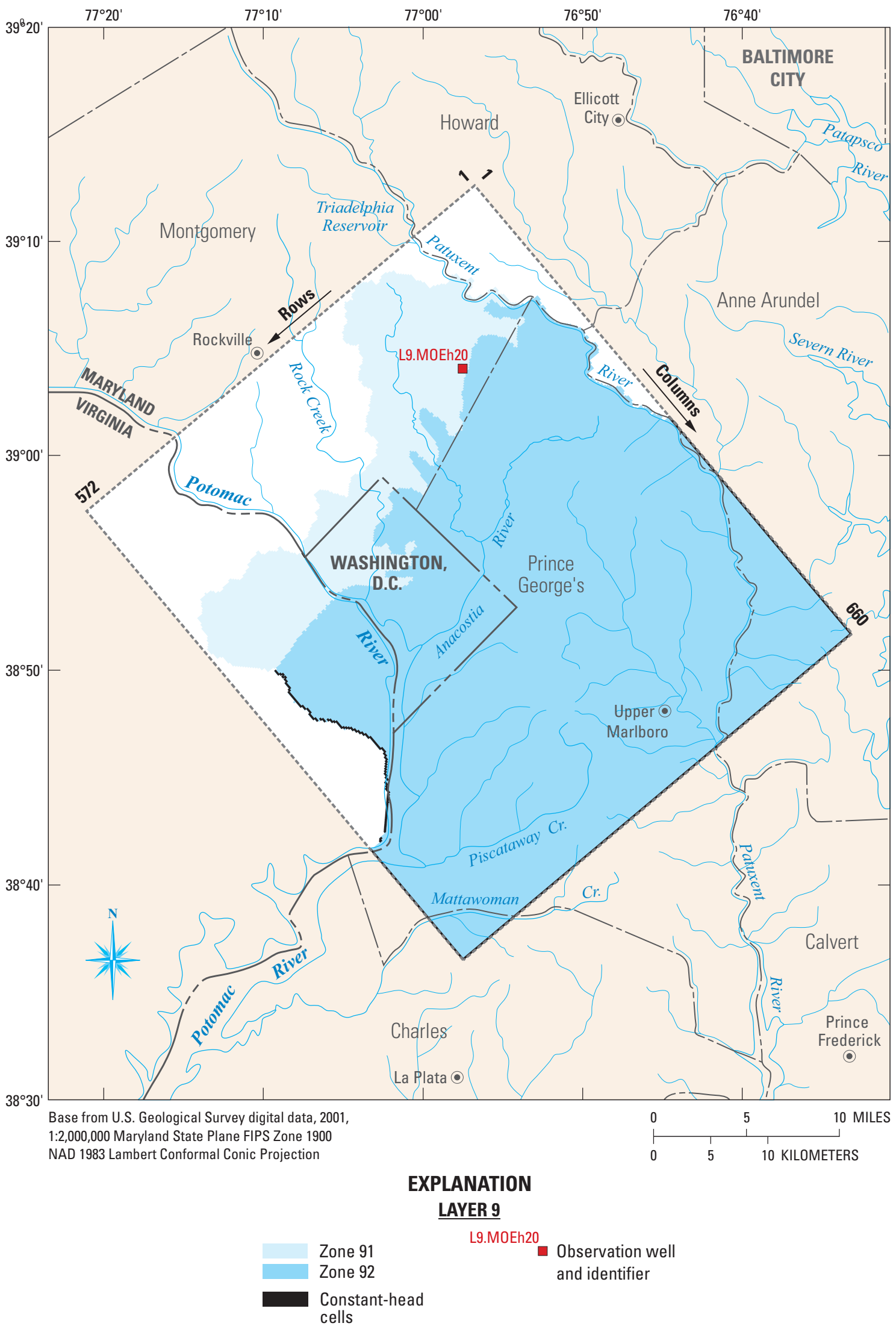

Figure 12. Layer extent and features, model layer 9 (unweathered Piedmont bedrock). 
Table 2. Summary of rules for determining layer elevations, including choices of Aquifer Information System (AIS) layers adopted for each flow model layer.

[Model elevation refers to the particular layer surface in the model that is generated; AIS surface refers to which surface layer from the AIS is applied to generate the model elevation surface; $n / a$, not applicable]

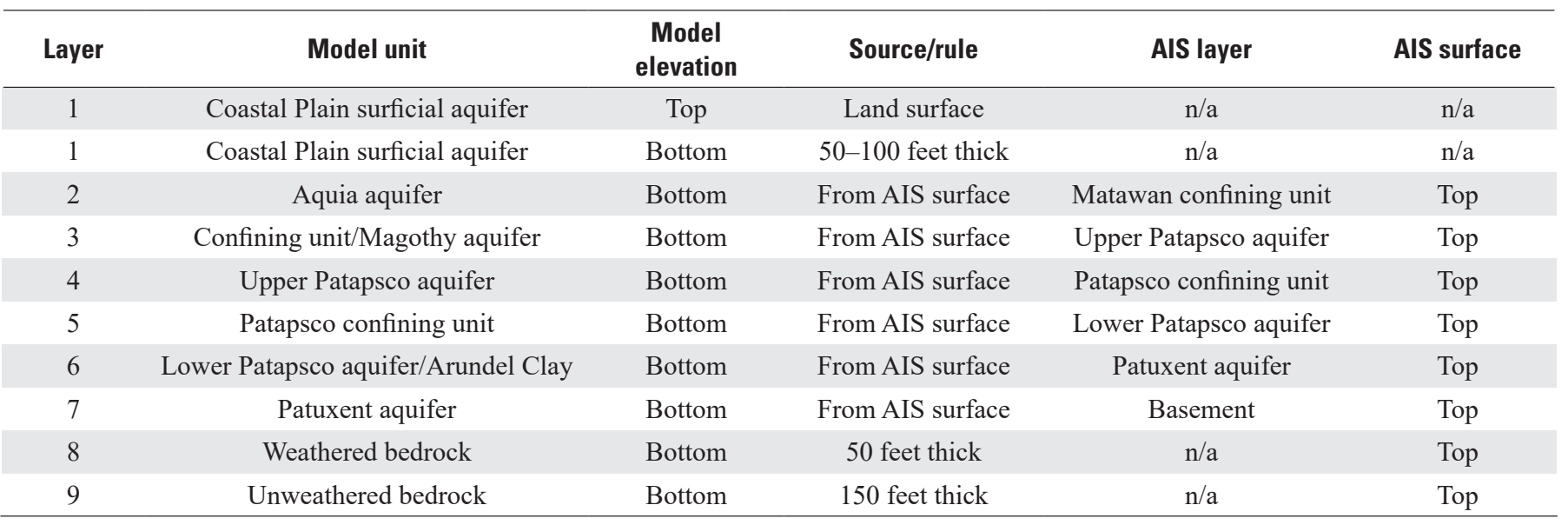

Table 3. Description of Aquifer Information System (AIS) hydrogeologic framework units and subcrop/outcrop areas corresponding to model zones. (Hydrogeologic framework names are from Andreasen and others, 2013).

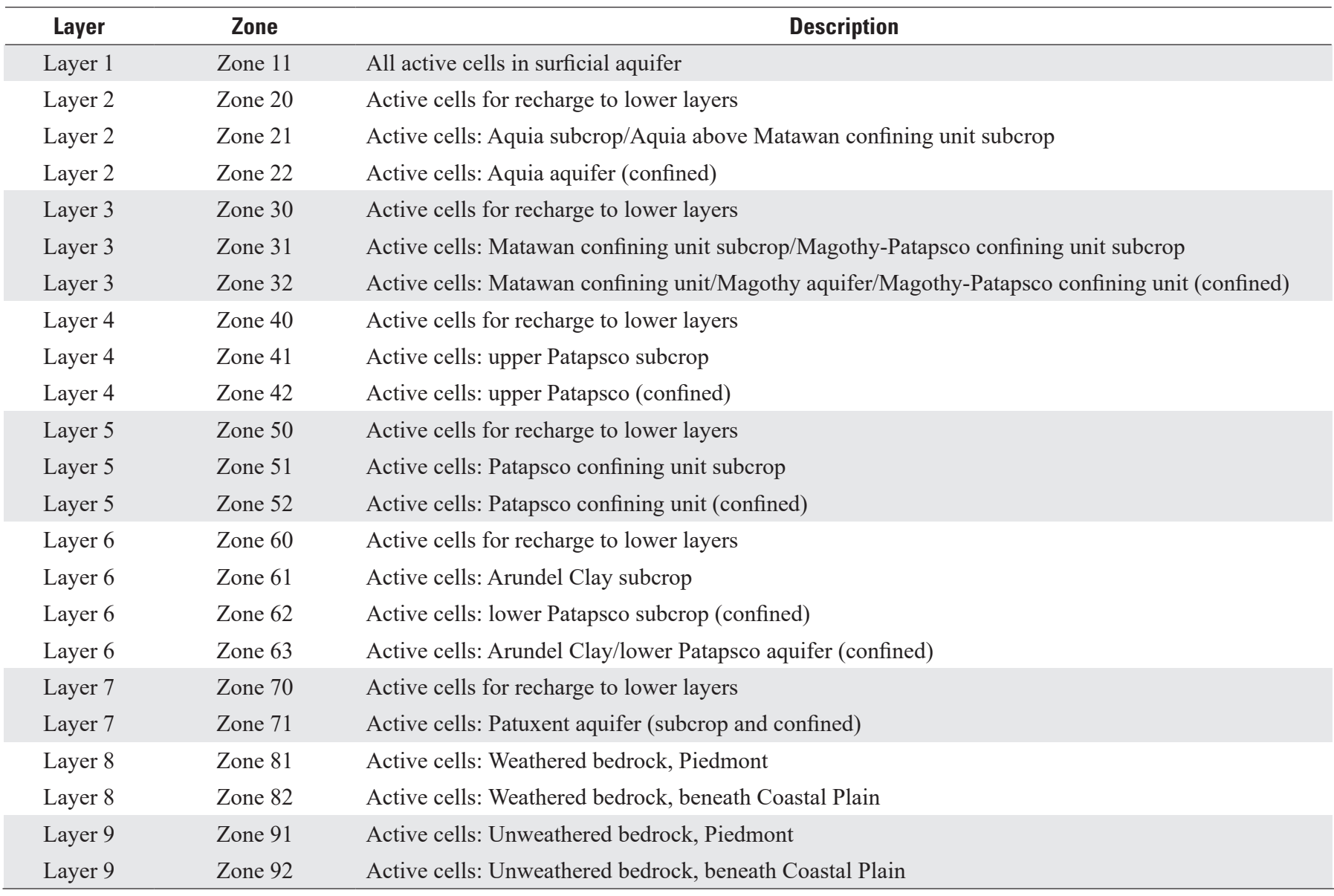


extent with layers 1,2 , and 3, but extend further downdip to the edges of the model domain. Piedmont and bedrock layers (8 and 9) extend northwest, beyond the extent of layers 1 through 7 , to the main stem of streams in the west and to the watershed divide of the Anacostia River and Rock Creek in the north.

The major regional aquifers in the model domain include the upper Patapsco (layer 4), the lower Patapsco (layer 6), and the Patuxent (layer 7). Water levels in these aquifers have been affected by pumping, especially downdip (Soeder and others, 2007). Although the model is steady state, pumping wells are included. Simulated drawdown caused by withdrawals from wells in proximity to downdip boundaries will depend on conditions specified at the boundaries. To account for potential influx of water from the lateral downdip model boundary in layers 4,6 , and 7 , the boundary was simulated as a constanthead boundary, by using water levels in the Patapsco and Patuxent aquifers extrapolated from potentiometric-surface maps for 2005 (Soeder and others, 2007). The lateral downdip model boundary in layer 5 was simulated as a no-flow boundary because generally, there is very little lateral groundwater flow in confining units. The constant-head values assigned to layer 7 were also assigned to the underlying basement rocks (layers 8 and 9). The locations of the constant-head boundaries are shown in figures 7 through 12. Tidal water in layer 1 is also modeled as a constant-head boundary. This includes the tidal Potomac and Anacostia Rivers, as well as smaller tidal parts of their tributaries (fig. 4).

\section{Model Stresses}

MODFLOW-NWT incorporates several hydrological processes that add terms to the governing equations representing inflows or outflows (Harbaugh, 2005). These may be thought of as stresses on the system that affect groundwater flow. The model includes one anthropogenic stress, which is associated with the withdrawal of groundwater by pumping wells. The model also includes three natural stresses: recharge, evapotranspiration, and base-flow discharge to rivers and streams.

\section{Reported Withdrawals}

Reported groundwater withdrawals for 2005 from the surficial, Magothy, upper Patapsco, lower Patapsco, and Patuxent aquifers, and from bedrock wells, by users permitted to withdraw more than 10,000 gallons per day (gal/d) (Raffensperger and others, 2010; table 4) were input to the model using the MODFLOW well (WEL) package. Withdrawals for the year 2005 were considered representative of the period 2000-10. All of these withdrawals occurred in Maryland. Washington, D.C. has a permit process for installation of wells, but currently does not have a permit process for reporting groundwater withdrawals. Although dewatering is expected, especially in the downtown area where the foundations of many commercial, mixed use, and government buildings extend below the groundwater table, the quantities could not be determined (Diane Douglas, DOEE, written commun., September 5, 2013); for the groundwater-flow model these values were considered negligible.

The data used are stored in the Maryland version of the USGS Site-Specific Water-Use Data System (MD SWUDS), which is part of the USGS National Water Information System (NWIS). Users are required to report pumpage for individual permits, which may involve one or more wells. An earlier modeling study (Raffensperger and others, 2010) examined the reported withdrawals in detail and subdivided reported quantities to estimate the amount withdrawn per well for many of the wells in the Anacostia model domain. Locational information and aquifer designation listed on the appropriations permit were used to determine model layer, row, and column for the wells shown in table 4 . Where information was missing or possibly erroneous, the well depths were compared with the layer elevations in the model to determine the correct vertical location and layer for the well. The location and magnitude of reported discharge from wells are shown in figures 4, 6, 7, 9, 10 , and 11 .

\section{Recharge and Evapotranspiration}

Recharge to the groundwater system was modeled using the recharge package (RCH) of MODFLOW-NWT. Total recharge to the groundwater system for this modeling study consists of infiltrating precipitation as well as return flows from septic systems and other sources. Within Washington, D.C., recharge could include unreported pumping (a negative recharge), as well as gains and losses from leaking infrastructure, sumps, and other anthropogenic sources and sinks that are difficult to quantify. Evapotranspiration was modeled using the EVT package of MODFLOW-NWT. Evapotranspiration rate depends on depth to the water table and other factors. The sum of the recharge rate, including anthropogenic sources and sinks, and the evapotranspiration rate is the net recharge rate.

Spatially variable recharge rates were assigned to layer 1 and the outcrop area of the bedrock (layer 8). These recharge rates were based on 2002 land use for Washington, D.C. (District of Columbia Office of Planning, 2009) and Maryland (Maryland Department of Planning, 2009). Land use for 2002 was considered representative of the period 2000-10. Recent investigators such as Risser (2008) related various land-use/ land-cover types to recharge rates. Other factors, such as soil properties and vegetation, can influence recharge but were not considered for this study. As shown in figure 3, initial recharge rates were assigned according to land-use classes, based on Risser (2008). These land-use classes and their recharge values included: wetlands, water bodies, and barren areas -1 inch per year (in/yr); bedrock outcrop area-3 in/yr; high-density urban, industrial and agricultural areas-7 in/yr; and open urban land and low-density residential areas- $12 \mathrm{in} / \mathrm{yr}$. Somewhat smaller initial recharge rates were used in the bedrock areas of layer 8 (fig. 3). Recharge was treated as an adjustable parameter during objective parameter estimation using UCODE_2005, with 
Table 4. Withdrawal wells used in the model, including model cell location and 2005 reported pumpage (Raffensperger and others, 2010).

[nr, not reported]

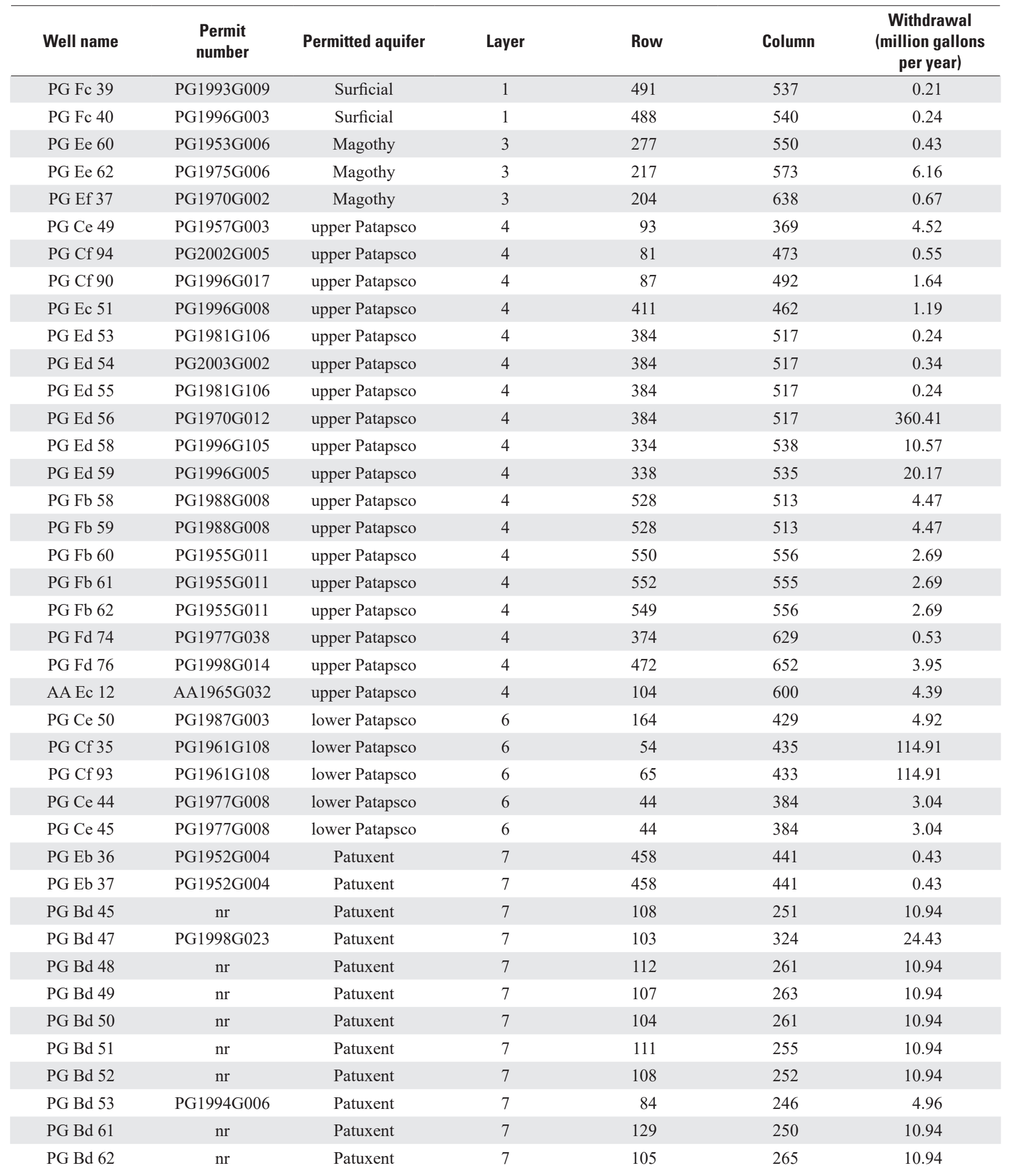


Table 4. Withdrawal wells used in the model, including model cell location and 2005 reported pumpage (Raffensperger and others, 2010).-Continued

[nr, not reported]

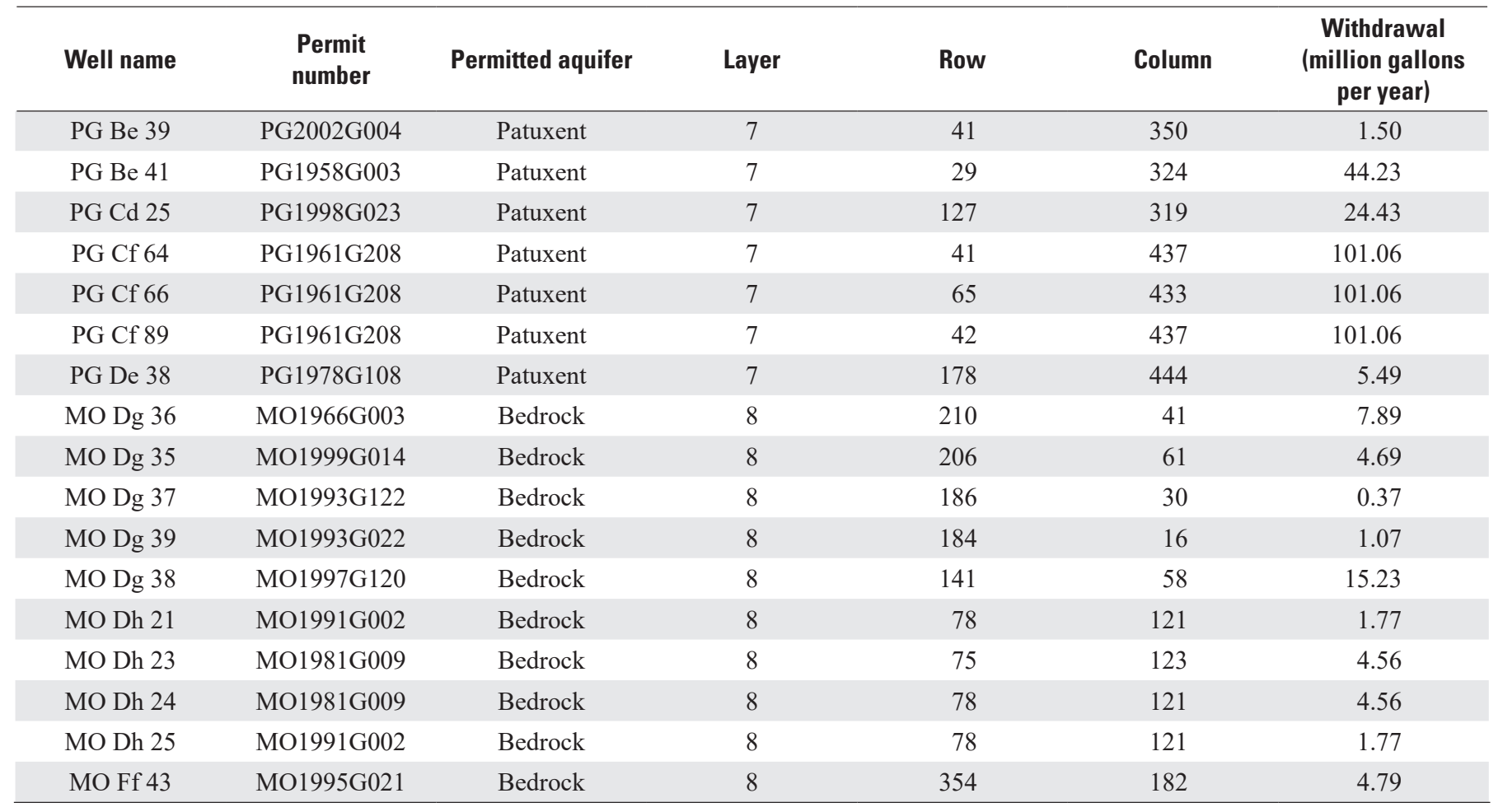

final recharge values generally different from initial values, but preserving ratios of final recharge values between the various land-use classes.

As with recharge, evapotranspiration was assumed to occur only in layer 1 and the outcrop area of layer 8. Evapotranspiration in MODFLOW-NWT requires specification of a maximum rate of evapotranspiration and an extinction depth. The maximum rate will occur when the water table is at or above the land surface. The rate will be zero at and below the extinction depth. The maximum rates used in the model are spatially variable and are identical to the assigned total recharge rates. The extinction depth is $10 \mathrm{ft}$ (fig. 3). The overall goal of modeling both total recharge and evapotranspiration in this manner is to clearly distinguish groundwater recharge and discharge areas based on topography. When the water table is at or close to the land surface, typically at lower elevations where groundwater discharge is expected, the evapotranspiration rate will be equal to or close to the total recharge rate, and therefore the net recharge will be close to zero. Conversely, groundwater recharge areas will occur at greater elevations where the water table is a few to tens of feet below the land surface. In these areas, evapotranspiration will be ineffective and net recharge will be identical to the specified total recharge.

\section{Rivers and Drains}

MODFLOW-2005 and MODFLOW-NWT support several packages that may be used to simulate groundwater interactions with nontidal streams and rivers. They each approach the problem using different levels of sophistication and data needs and in support of different study objectives (Harbaugh, 2005; Niswonger and others, 2011; Niswonger and Prudic, 2005). In this study, streams and nontidal rivers were simulated using the drain package (DRN) of MODFLOW-NWT. This approach was used by Sanford, Pope, and others (2012) for a model of the Delmarva Peninsula, and is relatively simple and imposes minimal data needs. In this approach, all flowing (nontidal) streams and rivers are represented as drains, which remove water from the aquifer at a rate proportional to the difference between the head in the aquifer and some fixed head or elevation, called the drain elevation, as long as the head in the aquifer is above that elevation (Harbaugh, 2005). If, however, the aquifer head falls below the drain elevation, the drain has no effect on head in the aquifer. The constant of proportionality is called the drain conductance. When using the drain approach, it is assumed that there are no losing reaches in the model domain.

Drains were simulated in the surficial aquifer represented by layer 1 (fig. 4) and in the outcrop area of layer 8 (fig. 11). For each active model cell traversed by a stream, the 
MODFLOW drain package requires specification of layer, row, column, bottom of drain elevation, and drain conductance. Stream locations were estimated from the 1:100,000 National Hydrography Dataset (NHDPlus) (U.S. Environmental Protection Agency, 2007). The model grid was overlain on the NHDPlus GIS dataset to identify the row and column of all model cells traversed by a stream reach, as well as the length of the stream segment within the cell. The stream elevations in each cell were initially estimated from the 30-m National Elevation Database (NED) (U.S. Geological Survey, 2006), and were later changed to a constant depth below land surface to better represent the actual pattern of perennial streamflows in the modeled region. The conductance of the stream was treated as a lumped parameter with the same value across the extent of the model domain. Stream conductance was calculated as the product of the hydraulic conductivity of the streambed sediments, length of the stream segment in the cell, and the width of the stream, divided by the thickness of the streambed sediments. The initial hydraulic conductivity of the streambed sediments was 0.1 feet per day $(\mathrm{ft} / \mathrm{d})$ for streams flowing over bedrock areas and with elevations greater than $200 \mathrm{ft}$ in the Coastal Plain sediments. The initial hydraulic conductivity of the streambed sediments for streams draining Coastal Plain sediments was $0.2 \mathrm{ft} / \mathrm{d}$ for elevations greater than $100 \mathrm{ft}$ and less than or equal to $200 \mathrm{ft}$; $0.3 \mathrm{ft} / \mathrm{d}$ for elevations greater than $75 \mathrm{ft}$ and less than or equal to $100 \mathrm{ft}$; and $0.5 \mathrm{ft} / \mathrm{d}$ for elevations less than $75 \mathrm{ft}$. Drain conductance and streambed sediment conductivity values were adjusted during model calibration using objective parameter estimation and UCODE_2005.

\section{Hydraulic Properties}

The hydraulic properties of an aquifer system at steady state govern the transmission of groundwater. Hydraulic properties input into the model include horizontal hydraulic conductivity and either vertical hydraulic conductivity or vertical anisotropy (ratio of horizontal to vertical hydraulic conductivity) for all active cells in all model layers. Because the model includes true layer geometry and implicitly accounts for aquifer thickness, only hydraulic conductivity values need to be specified. Ultimately, the cell geometry and horizontal and vertical hydraulic conductivity values are used by MODFLOW-NWT to calculate cell conductances (Harbaugh, 2005).

Initial hydraulic properties were estimated using a variety of approaches. These are referred to as initial values because some, but not all, hydraulic properties were adjusted during objective parameter estimation using UCODE_2005. All initial property values are provided in figure 3. The approaches used to estimate the initial property values included a review of the literature, especially of groundwater-flow models constructed for the region, calibration of a preliminary model at a coarser resolution, and a classification and analysis of lithologic descriptions for surficial material in layer 1 .

A review of the literature was conducted in order to provide additional estimates of the hydraulic conductivity of aquifers and confining units. The sources of data for the initial hydraulic conductivity of each model layer are listed in table 5. Lithologic descriptions of cores collected at the South Capitol Street Bridge in Washington, D.C. by MACTEC Engineering and Consulting, Inc. (2005) were compared to lithologic descriptions of the same area by Southworth and Denenny (2006). The lithologic descriptions of sediments by Southworth and Denenny (2006) and MACTEC Engineering and Consulting, Inc. (2005) in this area are consistent.

A coarser resolution preliminary model was constructed and used to refine the initial property estimates. The preliminary model used a regular grid of 500 by $500 \mathrm{ft}$ cells and did not include layer geometry or the detailed hydrogeologic framework of Andreasen and others (2013) to define the extent and outcrop/subcrop areas for the Coastal Plain aquifers and confining units. However, manual calibration was performed, using observations of water levels and stream base flow at four

Table 5. Sources of data for initial hydraulic property values for the Anacostia, Potomac, and Patuxent River watershed model, Washington, D.C. and Maryland.

[Logan, Logan (1999); Layne, Layne Geosciences, Inc. (1998); Drummond, Drummond (2007); PP1404-J, Fleck and Vroblesky (1996); C697, Papadopulos and others (1974)]

\begin{tabular}{lll}
\hline & \multicolumn{1}{c}{ Horizontal hydraulic conductivity } & \multicolumn{1}{c}{ Vertical hydraulic conductivity } \\
\hline Layer 1-Surficial aquifer & Logan, Drummond & Layne Geosciences \\
\hline Layer 2-Aquia aquifer & Logan, Drummond & Logan, Drummond \\
\hline Layer 3-Confining units/Magothy aquifer & Logan, Drummond & Logan \\
\hline Layer 4-Upper Patapsco aquifer & Logan, Drummond, PP1404-J, C697 & Logan, PP1404-J, C697 \\
Layer 5-Patapsco confining unit & Logan, Drummond, PP1404-J, C697 & Logan, PP1404-J, C697 \\
Layer 6-Lower Patapsco aquifer & Logan, Drummond, PP1404-J, C697 & Logan, PP1404-J, C697 \\
\hline Layer 7-Patuxent aquifer & Logan, PP1404-J, C697 & Logan, PP1404-J, C697 \\
Layer 8-Weathered bedrock & Logan & Logan \\
\hline Layer 9-Unweathered bedrock & & \\
\hline
\end{tabular}


gaged sites in the model domain, which in turn allowed for refinement of the initial model inputs (fig. 3).

Initial hydraulic properties for surficial (layer 1) deposits were estimated based on lithologic descriptions provided by Dicken and others (2005) and Southworth and Denenny (2006). The geologic units described in table 1 and shown in figure 2 were classified as sedimentary, crystalline, or unconsolidated sediments, and an initial horizontal hydraulic conductivity $(\mathrm{K})$ was assigned based on the classification and lithology (table 6). In general, crystalline rocks were assigned relatively low initial hydraulic conductivity values and unconsolidated sediments were assigned relatively high values. The values assigned to sedimentary rocks were dependent on lithology, with clays assigned lower values and sands and gravels assigned higher values. Where geologic units are not exposed at the surface because they are under water, an arbitrary value of $10 \mathrm{ft} / \mathrm{d}$ was assigned. These submerged areas are all modeled as constant-head cells or drain cells. The vertical anisotropy for all materials in layer 1 was assumed fixed at 1.0 and was not allowed to vary during the course of the calibration.

\section{Model Calibration and Sensitivity Analysis Approach}

Model calibration involves the adjustment of model inputs so that the differences between simulated and measured quantities (errors) are minimized with respect to an objective function. During calibration, model input such as system geometry and hydraulic properties, initial and boundary conditions, and stresses are changed so that model output matches related measured values. Many of the model inputs that are changed can be characterized using what are called "parameters" (Hill and Tiedeman, 2007). The measured values are referred to as "observations" or "observed values." Effective use of system information and observations to constrain a model is likely to produce a model that more accurately represents the simulated system and produces more accurate model predictions, compared to a modeling procedure that uses these types of data less effectively. This section of the report describes the calibration method, the treatment of observations, and sensitivity analysis methods.

Prior to the development of objective parameter estimation (Cooley and others, 1986; Hill and others, 2000; Hill and Tiedeman, 2007; Poeter and Hill, 1997; Poeter and others, 2005), sensitivity analysis was an exercise conducted after trial-and-error model calibration, by examining the impact of variations in model inputs on the simulation output or errors. With these recent developments, parameters often are estimated only after using starting values to evaluate model fit and perform a sensitivity analysis to identify insensitive and correlated parameters. Fit-independent statistics are calculated using sensitivities, and do not use the residual in the calculation of the statistic. These statistics were calculated during calibration of the Anacostia model, and provided important guidance for model development and calibration. Finally, the nonlinear least-squares regression method used by UCODE_2005 involves calculation of perturbation sensitivities in estimating objective and optimal parameter values. The methods used to calculate sensitivities and fit-independent statistics are presented at the end of this section.

\section{Nonlinear Least-Squares Regression Method}

The match of observed to simulated values is one of the most important indicators of how well a model represents an actual system. Objective functions measure this fit by quantitatively comparing simulated and observed values. The simulated and observed values include easily measurable system-dependent variables such as hydraulic head and stream base-flow contributions. Model calibration efforts mainly involve attempting to construct a model that produces the "best fit" to observed heads and flows. When the objective function is defined as the sum of squared differences between simulated and observed heads and flows, the goal of the calibration is to find the set of model parameters that makes this sum as small as possible. Methods such as regression provide a rigorous mathematical framework within which optimal parameter values that produce the best fit given the constructed model can be identified. The resulting parameter values are said to be optimal, optimized, or estimated by the regression (Hill and Tiedeman, 2007).

Using hydraulic heads and flows as the observations, the weighted least-squares objective function (see Hill and Tiedeman, 2007), $S(\mathbf{b})$, can be expressed as:

$$
\begin{gathered}
S(\mathbf{b})=\sum_{i=1}^{N H} \omega_{h_{i}}\left[y_{h_{i}}-y_{h_{i}}^{\prime}(\mathbf{b})\right]^{2}+ \\
\sum_{j=1}^{N Q} \omega_{q_{j}}\left[y_{q_{j}}-y_{q_{j}}^{\prime}(\mathbf{b})\right]^{2}
\end{gathered}
$$

where

$$
\begin{aligned}
& \text { b } \quad=\text { a vector containing values of each of the } N P \\
& \text { parameters being estimated; } \\
& N P \quad=\text { the number of estimated parameters; } \\
& N H \quad=\text { the number of hydraulic-head observations; } \\
& N Q \quad=\text { the number of flow observations; } \\
& y_{h_{i}} \quad=\text { the } i \text { th observed hydraulic head being } \\
& \text { matched by the regression; } \\
& \begin{aligned}
y_{h_{i}}^{\prime}(\mathbf{b}) \quad=\text { the simulated hydraulic head that } \\
\text { corresponds to the } i \text { th observed hydraulic }
\end{aligned} \\
& \text { head (a function of b); } \\
& y_{q_{j}} \quad=\text { the } j \text { th observed flow being matched by the } \\
& \text { regression; } \\
& y_{q_{j}}^{\prime}(\mathbf{b})=\text { the simulated flow that corresponds to the } \\
& j \text { th observed flow (a function of } \mathbf{b} \text { ); } \\
& \omega_{h_{i}} \quad=\text { the weight for the } i \text { th head observation; and } \\
& \omega_{q_{j}}=\text { the weight for the } j \text { th flow observation. }
\end{aligned}
$$


Table 6. Lithologic classification and initial hydraulic conductivity values for materials in model layer 1.

[K, hydraulic conductivity; Index, index numbers shown in figure 2]

\begin{tabular}{|c|c|c|c|}
\hline Geologic unit & Classification & $\begin{array}{c}\text { Initial K } \\
\text { (feet per day) }\end{array}$ & Index \\
\hline Marlboro Clay & Sedimentary & 0.0001 & 16 \\
\hline Baltimore Gabbro Complex & Crystalline & 0.01 & 35 \\
\hline Wissahickon Formation; boulder gneiss & Crystalline & 0.01 & 36 \\
\hline Potomac Group clay-dominated lithofacies & Sedimentary & 0.01 & 10 \\
\hline Aquia Formation & Sedimentary & 0.01 & 13 \\
\hline Wissahickon Formation; lower pelitic schist & Crystalline & 0.01 & 37 \\
\hline Georgetown Intrusive Suite; biotite-hornblende tonalite & Crystalline & 0.01 & 38 \\
\hline Indian Run Formation & Crystalline & 0.01 & 39 \\
\hline Occoquan Granite & Crystalline & 0.01 & 40 \\
\hline Sykesville Formation diamictite & Crystalline & 0.01 & 41 \\
\hline Matawan Formation & Sedimentary & 0.05 & 2 \\
\hline Chesapeake Group; Calvert Formation & Sedimentary & 0.05 & 6 \\
\hline Monmouth Formation & Sedimentary & 0.05 & 3 \\
\hline Brightseat Formation and Monmouth Group, undivided & Sedimentary & 0.05 & 15 \\
\hline Monmouth Formation & Sedimentary & 0.5 & 3 \\
\hline Potomac Group & Sedimentary & 0.5 & 4 \\
\hline Pamunkey Group; Aquia Formation & Sedimentary & 0.5 & 5 \\
\hline Pamunkey Group; Nanjemoy Formation & Sedimentary & 0.5 & 7 \\
\hline Potomac Group & Sedimentary & 0.5 & 9 \\
\hline Potomac Group sand-dominated lithofacies & Sedimentary & 0.5 & 11 \\
\hline Severn Formation & Sedimentary & 0.5 & 12 \\
\hline Calvert Formation & Sedimentary & 0.5 & 14 \\
\hline Nanjemoy Formation & Sedimentary & 0.5 & 17 \\
\hline Yorktown Formation and Bacons Castle Formation & Sedimentary & 0.5 & 18 \\
\hline Lowland deposits & Unconsolidated & 1 & 19 \\
\hline Upland deposits & Unconsolidated & 1 & 20 \\
\hline Disturbed ground and artificial fill & Unconsolidated & 1 & 21 \\
\hline Alluvium & Unconsolidated & 1 & 22 \\
\hline Colluvium & Unconsolidated & 1 & 23 \\
\hline Debris & Unconsolidated & 1 & 24 \\
\hline Upper level fluvial and estuarine deposits & Unconsolidated & 1 & 25 \\
\hline Landslide & Unconsolidated & 1 & 26 \\
\hline Terrace deposit, low level & Unconsolidated & 1 & 27 \\
\hline Low level fluvial and estuarine deposits & Unconsolidated & 1 & 28 \\
\hline Terrace deposits, upper level & Unconsolidated & 1 & 29 \\
\hline Terrace deposits & Unconsolidated & 1 & 30 \\
\hline Highest level upland terrace deposits & Unconsolidated & 1 & 31 \\
\hline Pliocene sand and gravel & Unconsolidated & 1 & 32 \\
\hline Shirley Formation & Unconsolidated & 1 & 33 \\
\hline Bacons Castle Formation; gravel & Unconsolidated & 1 & 34 \\
\hline Water & Water & 10 & 1 \\
\hline
\end{tabular}


In theory, the objective function can be used to produce a model that accurately represents a system and provides reliable measures of model uncertainty only if three conditions are met. Two of these conditions relate to true errors, which equal the unknown amounts by which an observation differs from the value in the actual system. The conditions are: (1) relevant processes, system geometry, and so forth are adequately represented and simulated; (2) true errors of the observations are random and have a mean of zero; and (3) weighted true errors are independent, which means that the weighting needs to be proportional to the inverse of the variance-covariance matrix on the true observation errors (Hill and Tiedeman, 2007). The true errors are unknown and therefore cannot be analyzed. Instead, weighted residuals are investigated and the characteristics of the true errors are inferred. Mathematically, conditions 2 and 3 can be represented as:

$$
\begin{aligned}
& E(\boldsymbol{\varepsilon})=0 \\
& \boldsymbol{\omega}_{i} \propto 1 / \sigma_{i}^{2}
\end{aligned}
$$

where

$$
\begin{aligned}
E & =\text { the expected value or mean; } \\
\boldsymbol{\varepsilon} & =\text { a vector of true errors; } \\
\boldsymbol{\omega} & =\text { the weight matrix; and } \\
\sigma_{i}^{2} & =\text { the variance of the true error of observation } \\
& i .
\end{aligned}
$$

For a diagonal weight matrix; see Hill and Tiedeman, 2007, p. 28-31.

Weighting performs two related functions. First, weighting is needed to produce weighted residuals that have the same units so that they can be squared and summed using the equation above. Second, weighting is needed to reduce the influence of observations that are less accurate relative to those that are more accurate. Hence the weights are proportional to the variance, which is a measure of the accuracy of the observation. This is referred to as error-based weighting. The inverse variance error-based weighting scheme provided by equation allows the incorporation of variables originating from different types of groundwater-flow processes into the model so that their different measurement accuracies are accounted for.

For this modeling study, weighting was important because both streamflow and water-level observations were used, which have different units and very different orders of magnitude. These observations also have very different errors, or variances, associated with them. Finally, weighting of the stream base flows was of special importance because a major goal of the model is to simulate groundwater fluxes to the tidal Anacostia River as accurately as possible. Since baseflow measurements are much more uncertain than streamflow measurements, the error variance for base flow is probably considerably larger than the error variance associated with streamflow.
For many observations, errors are typically thought to be proportional to the true value so that:

$$
\mathbf{y}=\mathbf{y}^{\text {true }}(1+\boldsymbol{\varepsilon})=\mathbf{y}^{\text {true }}+\mathbf{y}^{\text {true }} \boldsymbol{\varepsilon}
$$

where

$$
\begin{aligned}
\mathbf{y} & =\text { the vector of observations; and } \\
\mathbf{y}^{\text {true }} & =\text { the vector of true, unknown values. }
\end{aligned}
$$

Therefore, one appropriate weighting strategy can be achieved by specifying the coefficient of variation as the statistic from which the weight is calculated, and using observed or simulated values to estimate $\mathbf{y}^{\text {true }}$. The variance is then calculated as $[(c . v \text {. }) \mathrm{x} a]^{2}$, where $c . v$. is the coefficient of variation and $a$ is the observed or simulated value. The standard deviation equals $[($ c.v. $) \mathrm{x} a]$. UCODE_2005 supports using either observations or simulated values to calculate weights (Poeter and others, 2005).

Error-based weighting provides a way for data-error analysis to be formally included in model development. An approach that is consistent with $\omega_{i i} \propto 1 / \sigma_{i}^{2}$ is to define the weighting in an attempt to achieve the stricter requirement that:

$$
\omega_{i i}=1 / \sigma_{i}^{2}
$$

Setting the weights to be equal to, rather than proportional to, the observation error variance results in some very useful properties, and is one approach used by UCODE_2005.

UCODE_2005 was used to estimate the optimal parameter values. Parameters are estimated using nonlinear regression: the weighted least-squares objective function is minimized with respect to the parameter values using a modified Gauss-Newton method or a double-dogleg technique (Poeter and others, 2005). Sensitivities needed for the method are calculated by UCODE_2005 using a forward- or central-difference perturbation technique.

\section{Residuals and Weighted Residuals}

Residuals were calculated as:

$$
\left[y_{i}-y_{i}^{\prime}(\mathbf{b})\right]
$$

They represent the deviation between simulated and observed values. For a diagonal weight matrix, weighted residuals are calculated as:

$$
\omega_{i}^{1 / 2}\left[y_{i}-y_{i}^{\prime}(\mathbf{b})\right]
$$

and are dimensionless. Weighted residuals represent the fit of the regression in the context of the expected accuracy of the observations. Observations expected to be less accurate are de-emphasized when weighted residuals are considered; 
observations expected to be more accurate are emphasized. The approach used to weight the observations is described in the next section.

\section{Observations Used in Model Calibration}

Observations provide information about model construction and parameter definition (parameterization) as well as the value of model parameters (Hill and Tiedeman, 2007). Successful model calibration is often dependent on multiple observation types; water levels (hydraulic head), base flow to streams, apparent groundwater ages, and solute concentrations have all been used to calibrate models (Hill and Tiedeman, 2007; Sanford and others, 2004). In this study, water levels from selected wells and estimates of base flow to streams with relatively long records were used to calibrate the steady-state groundwater-flow model.

\section{Water Levels and Associated Errors}

Groundwater-level observations were compiled for use in calibrating the model from the USGS NWIS database. A list of candidate wells that could be used was obtained from NWIS based on the extent of the model domain. The list was then reduced by eliminating wells outside the boundary of the layer containing the well, and by requiring that at least 10 observations existed for the period of record extending from water years 2000 through 2010, with no records ending prior to 2004. Observation wells in the Magothy and lower Patapsco aquifers were excluded because those aquifers are modeled as part of an aquifer-confining unit layer (layers 3 and 6, respectively). Finally, the well hydrographs were inspected for trends and wells exhibiting trends that were not consistent with the steady-state model assumption were eliminated. Observation wells demonstrating behavior that violated the assumption of steady-state flow were typically located near pumping centers and exhibited long-term declines in water levels. Seasonal variability was not a cause for elimination of candidate wells. Groundwater levels from a total of 34 wells were used for model calibration (table 7). No effort was made to reduce spatial clustering of the observations. For each well, the mean water level for the period from water year 2000 through 2010 was used as the head observation and the standard deviation and variance calculated for use in error-based weighting.

Errors that contribute the most uncertainty in water-level observations are associated with potential inaccuracies in the altitude and location given for a well, fluctuations introduced by variations in climate or any other nonsimulated transient stress, and measurement of a water level (Faunt and others, 2004; San Juan and others, 2004). These errors were estimated from available information and were used to quantify the uncertainty of a water-level observation.
Well-altitude error directly affects the calculation of the water level as referenced to a common datum. The error associated with the potential inaccuracy in well altitude was computed from the altitude accuracy code given in the USGS Ground-Water Site-Inventory (GWSI) System, expressed as a plus/minus $( \pm$ ) range related directly to the method by which the altitude was determined. This range varies from $\pm 0.01 \mathrm{ft}$ for high-precision methods, such as differential global positioning system (GPS) surveys, to $\pm 10 \mathrm{ft}$ for more uncertain estimates determined from topographic maps having large $(20-\mathrm{ft})$ contour intervals. The range defined by the altitude accuracy code is assumed to represent, with 95-percent confidence (two standard deviations) ${ }^{1}$, the true well-altitude uncertainty. Assuming that the head observation represents the mean value and that the error is normally distributed, the uncertainty of the head observation, with respect to the wellaltitude error, can be expressed as a standard deviation by the following equation:

$$
\sigma_{\text {alt }}=A A C / 1.96
$$

where

$$
\begin{aligned}
\sigma_{a l t}= & \text { the standard deviation; and } \\
A A C= & \text { the value of the GWSI altitude accuracy } \\
& \text { code, in feet. }
\end{aligned}
$$

The standard deviation for well-altitude error ranges from 0.0051 to $2.55 \mathrm{ft}$.

Well-location errors can also cause a discrepancy between observed and simulated water levels. The magnitude of this discrepancy depends directly on the hydraulic gradient at the well-the steeper the gradient, the greater the discrepancy. Well-location error was calculated as the product of the distance determined from the coordinate accuracy code values given in GWSI and the hydraulic gradient estimated for a given well location. Latitude and longitude coordinate accuracy codes given for wells in the model domain range from about 0.1 to 1 second. In the model region, a second represents approximately $25-30 \mathrm{~m}(90 \mathrm{ft})$. Accordingly, the largest distance accuracy that could be computed for a well in the Anacostia model domain would be about $\pm 90 \mathrm{ft}$. The hydraulic gradient at an individual well could not be estimated from available information and so was set to 0.001 for all wells. The range defined by the value of the coordinate accuracy code is assumed to represent, with 95-percent confidence (or two standard deviations), the true error in the head observation as related to well-location uncertainty. Assuming that the head observation represents the mean value and that the error is normally distributed, the uncertainty of the head observation,

\footnotetext{
${ }^{1}$ Throughout this section, 1.96 is used as the approximate value of the 97.5 percentile point of the normal distribution; 95 percent of the area under a normal curve lies within roughly 1.96 standard deviations of the mean, and this number is therefore used in the construction of approximate 95-percent confidence intervals.
} 
Table 7. Observation wells used to calibrate the groundwater-flow model, with associated observations, errors (variance), weights, and weighted observations.

[Observation name, text title given to observations in the UCODE_2005 and MODFLOW-NWT input files (names must begin with a letter); ft, feet; asl, above sea level; $\mathrm{ft}^{2}$, square feet]

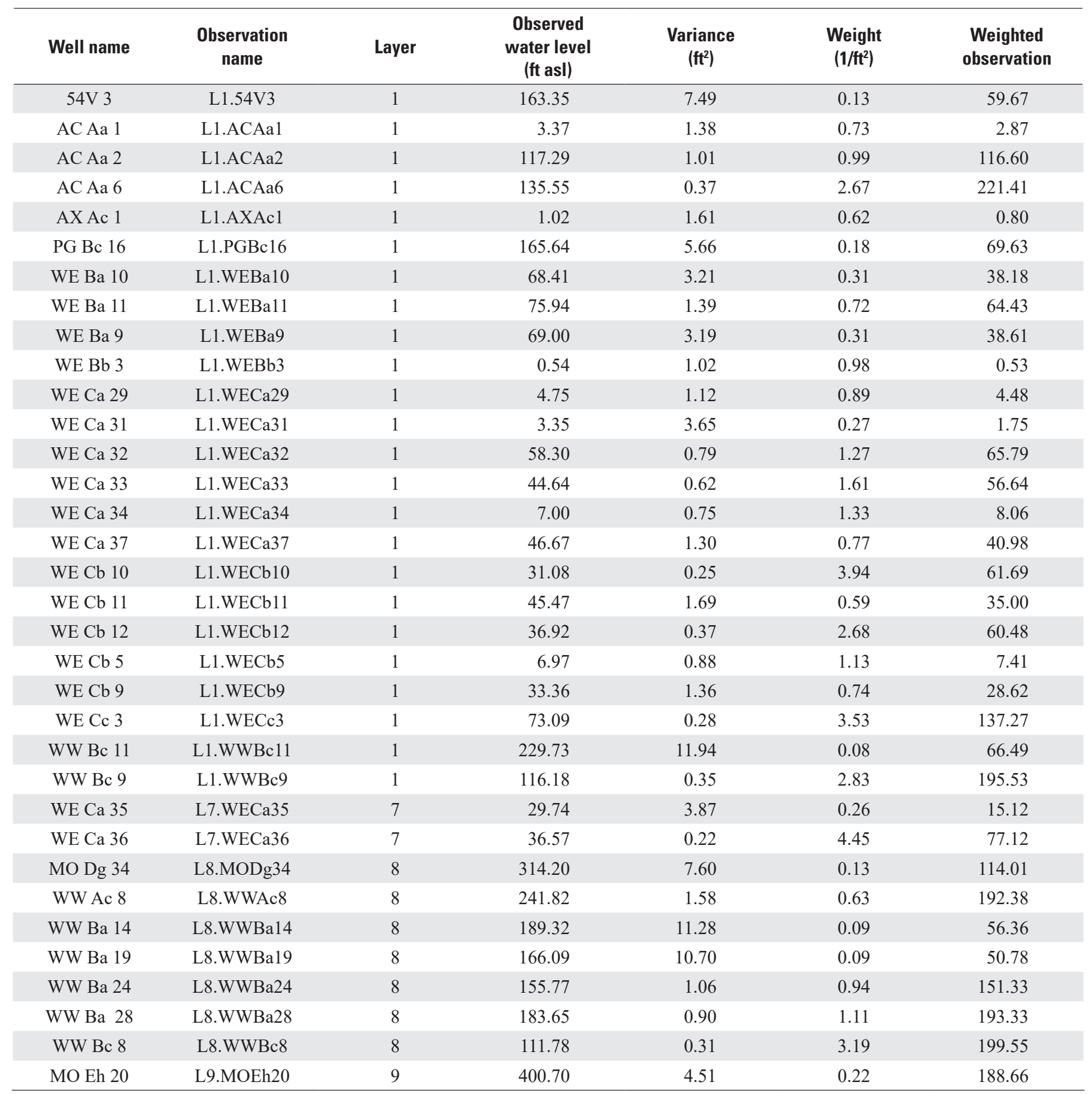


with respect to the well-location error, can be expressed as a standard deviation calculated by the following equation:

$$
\sigma_{l o c}=(C A C / 1.96) \times H G
$$

where

$$
\begin{aligned}
\sigma_{l o c} & =\text { the standard deviation; } \\
C A C & =\text { the value of the GWSI coordinate accuracy } \\
& \text { code, in feet; and } \\
H G= & \text { the hydraulic gradient (assumed to be } \\
& 0.001) .
\end{aligned}
$$

Using this equation, the standard deviation associated with well-location error ranges from 0.0005 to $0.046 \mathrm{ft}$.

Nonsimulated transient errors result from uncertainty in the magnitude of water-level response caused by stresses not simulated in the flow model, and are typically associated with seasonal and long-term climate changes. Seasonal water-level fluctuations of nearly several feet have been measured in shallow wells in the model region. The standard deviation caused by seasonal variations over the period of analysis (2000-10) was used to represent the nonsimulated transient error. For the 34 observation wells, the standard deviation ranges from 0.223 to $3.20 \mathrm{ft}$. The long-term climatic response in the waterlevel record is much more difficult to discern and commonly is masked by pumping effects. Long-term climatic response is unknown but is believed to be relatively small throughout the region (less than $1.0 \mathrm{ft}$ ). The potential error associated with long-term climate response at a well was not calculated independently but was instead accounted for by adding $1.0 \mathrm{ft}$ to the seasonal fluctuation assigned to each well (San Juan and others, 2004). The potential error associated with long-term climate response at a well was not calculated independently but was instead accounted for by adding $1.0 \mathrm{ft}$ to the seasonal fluctuation assigned to each well. The range defined by this sum is assumed to represent, with 95-percent confidence (or two standard deviations), the true error in the head observation as related to nonsimulated transient uncertainty. Assuming that the head observation represents the mean value and that the error is normally distributed, the uncertainty of the head observation attributed to nonsimulated transient error can be expressed as a standard deviation calculated by the following equation:

$$
\sigma_{\text {tran }}=(S F+L T C / 4)
$$

where

$$
\begin{aligned}
\sigma_{\text {tran }} & =\text { the standard deviation; } \\
S F & =\text { the seasonal fluctuation as defined by water- } \\
& \text { level measurements, in feet; and } \\
\text { LTC } & \text { the long-term climate trend defined as } 1 \\
& \quad \text { foot. }
\end{aligned}
$$

The standard deviation in head error observed at the 34 wells due to non-simulated, transient effects ranges from 0.473 to $3.45 \mathrm{ft}$.

In addition to errors associated with well altitude and location and non-simulated transient fluctuations, measurement errors can also result from inaccuracies in the instruments used to measure depth to water. In this case, measurement accuracy depends primarily on the device being used to make the measurement. Most water-level measurements by the USGS Maryland-Delaware-D.C. Water Science Center are made using either a steel tape or an electric tape, both with an accuracy of $\pm 0.01 \mathrm{ft}$, although other factors, including human error, can affect the overall accuracy. Assuming that the head observation represents the mean value and that the error is normally distributed, the uncertainty of the head observation, with respect to the measurement-accuracy error, can be expressed as a standard deviation calculated by the following equation:

$$
\sigma_{\text {meas }}=0.01 / 1.96=0.0051
$$

where

$$
\begin{aligned}
\sigma_{\text {meas }}= & \text { the standard deviation; and } \\
0.01= & \text { the assumed accuracy of steel and electric } \\
& \text { tapes, in feet. }
\end{aligned}
$$

The standard deviation for measurement error at all 34 wells is $0.0051 \mathrm{ft}$.

Finally, the head variances due to all errors can be summed and the standard deviation of head observation error $\left(\sigma_{h}\right)$ calculated as:

$$
\sigma_{h}=\left(\sigma_{\text {alt }}^{2}+\sigma_{\text {loc }}^{2}+\sigma_{\text {tran }}^{2}+\sigma_{\text {meas }}^{2}\right)^{1 / 2}
$$

UCODE_2005 allows for the errors to be input as a scaled standard deviation, scaled variance, or as a scaled coefficient of variation, or by directly entering the weight or the square root of the weight. For the Anacostia model, the head variances were included in the observation file for heads.

\section{Streamflow Observations and Associated Errors}

Base flow was estimated for four streamflow-gaging stations including: Watts Branch at Washington, D.C. (USGS station number 01651800); Northwest Branch Anacostia River near Hyattsville, Md. (USGS station number 01651000); Northeast Branch Anacostia River at Riverdale, Md. (USGS station number 01649500); and Western Branch at Upper Marlboro, Md. (USGS station number 01594526) (fig. 13, table 8 ). The basin area draining to these stations ranges from 3.28 to $89.7 \mathrm{mi}^{2}$, ensuring that a wide range of spatial scales was sampled for conditioning the model on base-flow contributions during the calibration. Mean annual base flow was estimated at the four stations using the PART program (Rutledge, 1998), which uses streamflow partitioning to estimate a daily record of groundwater discharge under the 
streamflow record. The program scans the record for days that fit a requirement of antecedent recession, designates base flow to be equal to streamflow on these days, then linearly interpolates the daily record of base flow for days that do not fit the requirement of antecedent recession.

Daily streamflow values reported by the USGS are typically considered to have an accuracy of $\pm 5 \%$ (Edward Doheny, USGS, oral commun., 2011). It is unknown what additional inaccuracy is introduced by using base-flow separation techniques. In this case, the modeler may choose to adjust the error and thereby alter the weight for observations thought to be more or less important to overall model performance (Hill and Tiedeman, 2007). For the four stream base-flow observations, a coefficient of variation of 1.0 percent was eventually used to calibrate the model, although this value was adjusted in the course of parameter estimation. A trial-and-error process was used to adjust the coefficient of variation on stream base-flow observations, in order to achieve the lowest error possible.

\section{Model Parameters}

A change in MODFLOW-2000 (Harbaugh and others, 2000) was the addition of the term "parameter" as used in parameter-estimation terminology. In earlier MODFLOW documentation, the term parameter was generally used to mean any input data value, such as the recharge flux at a cell. However, a more restricted definition of "parameter" is commonly used when dealing with statistical parameter-estimation theory (Draper and Smith, 1998). Therefore, in current usage, a parameter is a single value assigned to a variable used in the finite-difference groundwater-flow equation at one or more model cells. The definition of a parameter specifies which variable is being defined and the cells for which the parameter applies. For example, a parameter might define the aquifer hydraulic conductivity for a group of cells in a model layer, or a parameter might define the riverbed conductance for one or more reaches of a river.

When parameters are used, the data value for a cell is calculated as the product of the dimensionless scalar parameter value, which might apply to many cells, and a starting value for the hydraulic property or other model input that is defined for that cell. In the Anacostia model, parameters are defined for both list and layer data. List data refers to any type of data for which values are specified in some subset of the grid cells. The only package that is parameterized in the model using list data is the drain package, for which the drain hydraulic conductance is parameterized as parameter type DRN. Two drain parameters were defined, corresponding to drain cells in the Coastal Plain (layer 1, DRN_1) and Piedmont (layer 8, DRN_8) parts of the system.

Each MODFLOW package that incorporates layer data may have any number of types of data to be defined. The input instructions for a package indicate which data types can be defined using parameters. Each data type is given a specific name that must be included as part of the input data that defines a parameter of that type. Packages that use parameter values for layer data in the Anacostia model include the Upwind-Weighting (UPW) package of MODFLOW-NWT, which is analogous to the Layer-Property Flow (LPF) package of MODFLOW-2005 (parameter types HK, VK, and VANI), the recharge package (parameter type $\mathrm{RCH}$ ), and the evapotranspiration package (parameter type EVT). The parameters are defined in the respective packages. For layer data, parameter multipliers are defined using multiplier arrays. In this case, each multiplier array contains values for every cell in a layer, and the values can be individually referenced using a row and column index. There can be a different multiplier array for every layer to which the parameter applies, and these are identified when the parameter is defined.

To allow only some of the cells of a layer to be associated with a layer parameter, a capability called zonation is used. Like multiplier arrays, each zone array is named and contains values for every cell in a layer. Values in a zone array are integers. There can be a different zone array for every layer to which the parameter applies. When a parameter is defined, the zone array and one or more integer zone values are specified to denote which zone each cell in the array is located in. The parameter applies to cells at which the value of the zone array matches any one of the specified zone values; that is, the data value at a cell is the product of the multiplier array at the cell and the parameter value only if the value of the zone array matches one of the zone values specified for the parameter. Zonation in the Anacostia model was previously described earlier in the "Layering and Zonation" section and zones for each layer are shown in figures 4 through 12 .

A complete list of parameters defined for the model is given in table 9. Model parameters related to horizontal and vertical hydraulic conductivity were log-transformed. Logtransformation of parameters may be useful because the uncertainty of many parameters is best represented by a log-normal probability distribution (Hill and Tiedeman, 2007), and as a way of ensuring positive values (Hill, 1998). Not all model parameters were adjusted during model calibration. Initial sensitivity analyses of all model parameters were conducted to determine which were unlikely to be optimally estimated. This included all parameters for zones ending in zero, which represent areas that only allow recharge to deeper layers (fig. 3). Sensitivity analysis is described in the next section.

\section{Sensitivity Analysis}

Sensitivities are calculated as the derivatives of simulated values (such as heads and flows) with respect to the model parameters:

$$
\left.\left(\frac{\partial y_{i}^{\prime}}{\partial b_{j}}\right)\right|_{\mathbf{b}}
$$




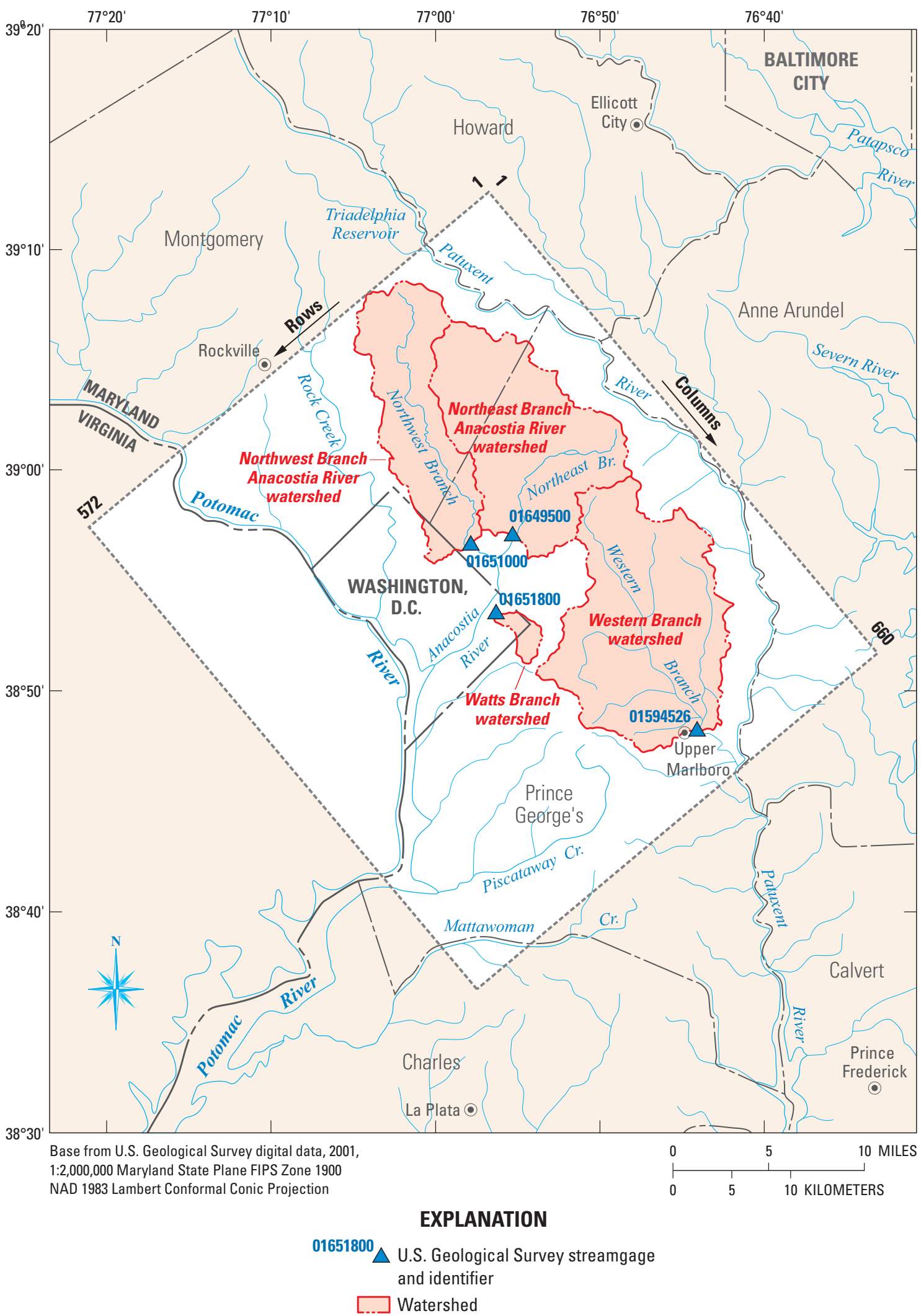

Figure 13. Streamgages and watersheds used in model calibration. 
where the terms have been defined previously. Sensitivities can be used to indicate the importance of head and flow observations to the estimation of parameter values. Observations are likely to be very valuable in estimating a parameter if the simulated head and flow values change substantially given a small change in model parameter value. Observations contribute very little to estimating a parameter if the simulated values change very little even with a large change in parameter value (Hill and Tiedeman, 2007).

Fit-independent statistics are calculated using sensitivities, and do not use the residual in the calculation of the statistic. The sensitivity analysis focused on identifying parameter values that could be estimated by regression and identifying key observations that supported each parameter. As part of this analysis, three types of statistics were evaluated: (1) dimensionless scaled sensitivity ( $d s s)$, (2) composite scaled sensitivity (css), and (3) parameter correlation coefficient ( $p c c)$.

\section{Dimensionless Scaled Sensitivity} as:

When a diagonal weight matrix is used, $d s s$ are calculated

$$
d s s_{i j}=\left.\left(\frac{\partial y_{i}^{\prime}}{\partial b_{j}}\right)\right|_{\mathbf{b}}\left|b_{j}\right| \omega_{i i}^{1 / 2}
$$

where

$$
\begin{aligned}
y_{i}^{\prime} & =\text { a simulated value associated with the } i \text { th } \\
& \text { observation; } \\
b_{j} & =\text { is the } j \text { th estimated parameter; } \\
\mathbf{b} & =\text { a vector containing the parameter values at } \\
& \text { which the sensitivities are evaluated; and } \\
\omega_{i i} & =\text { the weight on the } i \text { th observation. }
\end{aligned}
$$

Dss can be used to (1) compare the importance of different observations to the estimation of a single parameter $b_{j}$, and (2) compare the importance of different parameters to the calculation of a single simulated value $y_{i}^{\prime}$.

\section{Composite Scaled Sensitivity}

The analysis of overall model parameter sensitivity may be evaluated using css. They are calculated for each parameter using $d s s$ and may be calculated for some or all observations. The css (dimensionless) for the $j$ th parameter calculated for $N D$ observations is:

$$
c s s_{j}=\sum_{i=1}^{N D}\left[\left.\left(d s s_{i j}\right)^{2}\right|_{\mathbf{b}} / N D\right]^{1 / 2}
$$

The css indicates the magnitude to which a change in the value of the parameter causes a change in the simulated waterlevel observations. Highly sensitive parameters, therefore, exert greater control over the simulated water levels, whereas relatively insensitive parameters have less control over the simulated water levels. Css reflect the total amount of information provided by the observations in the estimation of one parameter, and therefore indicate the importance of observations as a whole to a single parameter.

\section{Parameter Correlation Coefficient}

$P c c$ used in conjunction with $c s s$ produce a useful sensitivity analysis (Hill and Tiedeman, 2007). Pcc provide a measure of the degree of linear dependence between pairs of parameters estimated during the regression. Linear dependence between parameters violates the assumptions of the regression and can provide biased estimates of regression

Table 8. Streamgages used to calibrate the groundwater-flow model, with associated observations, errors (variance), weights, and weighted observations.

[USGS, U.S. Geological Survey; ID, identifier; observation name, text title given to observations in the UCODE_2005 and MODFLOW-NWT input files (names must begin with a letter); $\mathrm{mi}^{2}$, square miles; $\mathrm{ft}^{3} / \mathrm{d}$, cubic feet per day; $\mathrm{CV}$, coefficient of variation; \%, percent; weighted observations are shown as negative quantities, as input into the model]

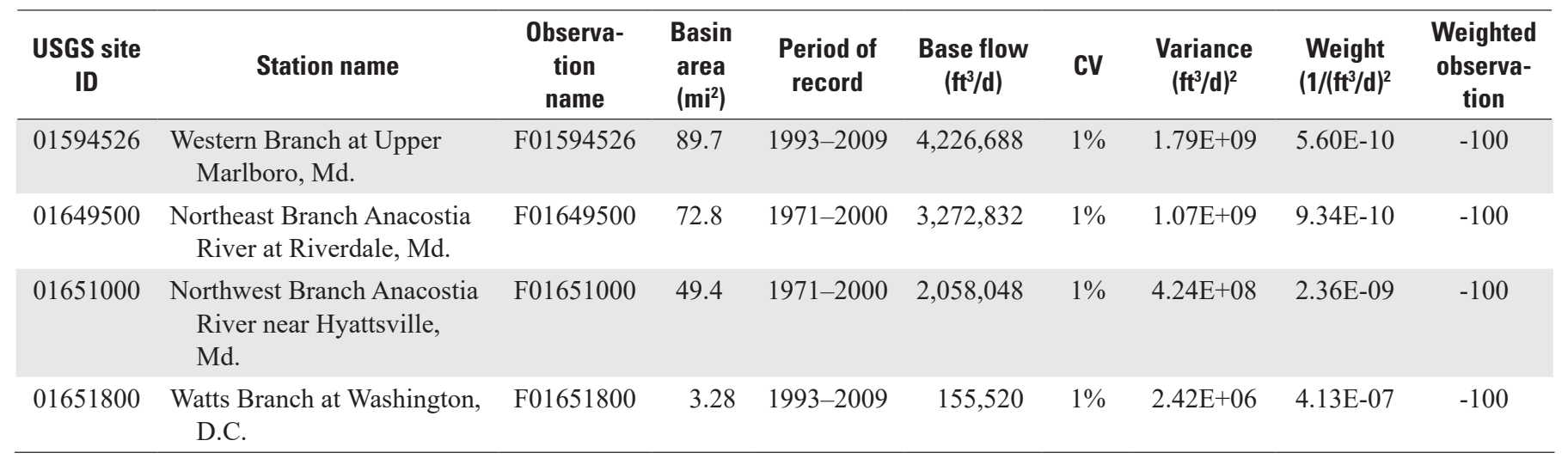


Table 9. List of all defined model parameters.

[Parameter identifier, text title used in MODFLOW input file to label the parameter; transform, whether logarithmic transformation during parameter estimation was enabled]

\begin{tabular}{|c|c|c|}
\hline Parameter identifier & Description & Transform \\
\hline HK_11 & Horizontal hydraulic conductivity of zone 11 & Yes \\
\hline HK_20 & Horizontal hydraulic conductivity of zone 20 & Yes \\
\hline HK_21 & Horizontal hydraulic conductivity of zone 21 & Yes \\
\hline HK_30 & Horizontal hydraulic conductivity of zone 30 & Yes \\
\hline HK_31 & Horizontal hydraulic conductivity of zone 31 & Yes \\
\hline HK_40 & Horizontal hydraulic conductivity of zone 40 & Yes \\
\hline HK_41 & Horizontal hydraulic conductivity of zone 41 & Yes \\
\hline HK_50 & Horizontal hydraulic conductivity of zone 50 & Yes \\
\hline HK_51 & Horizontal hydraulic conductivity of zone 51 & Yes \\
\hline HK_60 & Horizontal hydraulic conductivity of zone 60 & Yes \\
\hline HK_61 & Horizontal hydraulic conductivity of zone 61 & Yes \\
\hline HK_70 & Horizontal hydraulic conductivity of zone 70 & Yes \\
\hline HK_71 & Horizontal hydraulic conductivity of zone 71 & Yes \\
\hline HK_81 & Horizontal hydraulic conductivity of zone 81 & Yes \\
\hline HK_91 & Horizontal hydraulic conductivity of zone 91 & Yes \\
\hline VANI_11 & Vertical anisotropy ratio of zone 11 & No \\
\hline VANI_20 & Vertical anisotropy ratio of zone 20 & No \\
\hline VANI_21 & Vertical anisotropy ratio of zone 21 & No \\
\hline VK_30 & Vertical hydraulic conductivity of zone 30 & Yes \\
\hline VK_31 & Vertical hydraulic conductivity of zone 31 & Yes \\
\hline VANI_40 & Vertical anisotropy ratio of zone 40 & No \\
\hline VANI_41 & Vertical anisotropy ratio of zone 41 & No \\
\hline VANI_50 & Vertical anisotropy ratio of zone 50 & No \\
\hline VANI_51 & Vertical anisotropy ratio of zone 51 & No \\
\hline VK_60 & Vertical hydraulic conductivity of zone 60 & Yes \\
\hline VK_61 & Vertical hydraulic conductivity of zone 61 & Yes \\
\hline VANI_70 & Vertical anisotropy ratio of zone 70 & No \\
\hline VANI_71 & Vertical anisotropy ratio of zone 71 & No \\
\hline VANI_81 & Vertical anisotropy ratio of zone 81 & No \\
\hline VANI_91 & Vertical anisotropy ratio of zone 91 & No \\
\hline DRN_1 & Drain conductance for drain cells in layer 1 & No \\
\hline DRN_8 & Drain conductance for drain cells in layer 8 & No \\
\hline RCH_1 & Total recharge specified in layer 1 & No \\
\hline RCH_8 & Total recharge specified in layer 8 & No \\
\hline EVT_1 & Maximum rate of evapotranspiration for layer 1 & No \\
\hline EVT_8 & Maximum rate of evapotranspiration for layer 8 & No \\
\hline
\end{tabular}


coefficients. The $p c c$ are calculated for each possible pair of model parameters and are typically displayed as a matrix.

\section{Model Evaluation}

The calibrated Anacostia model was evaluated to assess the likely accuracy of simulated results. An advantage of using nonlinear regression to calibrate the model is that a substantial methodology exists for model evaluation that facilitates a better understanding of model strengths and weaknesses, and provides opportunity for future investigation of model parameter and model prediction uncertainty (D'Agnese and others, 1999; Faunt and others, 2004; Fienen and others, 2010; Hill and Tiedeman, 2007).

\section{Parameter Values and Model Fit}

In objective parameter estimation using nonlinear regression, the classical problem of model calibration is inverted, so that the observations are used to guide determination of the values of the variables in the governing equations. This entails an iterative process, not unlike traditional trial-anderror calibration, in which fit-independent statistics are used to guide the choice of parameters to be estimated, and the parameter estimates and model fit are then evaluated, alternate models considered, and the process is repeated until reasonable parameter estimates result.

The procedure for arriving at the final parameter values involved multiple sensitivity analysis and parameter estimation simulations. Model fit was evaluated after each set of simulations, by examining residuals (the differences between observed values and simulated values) and weighted residuals. An initial set of model runs was conducted to calculate sensitivities and fit-independent statistics ( $c s s, d s s$, and $p c c)$ for all 36 model parameters. Due to the lack of observations (34 water levels and 4 stream base-flow values), relatively few parameters could be reliably estimated. Css were very low for most parameters, and parameter correlation coefficients were large for many parameter pairs, especially those related to fluxes (RCH, EVT, DRN) and hydraulic conductivity parameters in the surficial aquifer (HK_11) and in other units that outcrop or subcrop near the surface. Furthermore, most of the water-level observations are in layer 1 and several layers have few or no observations, making parameter estimation difficult for those layers.

The final estimated parameters for the Anacostia model are provided in table 10, along with associated fit-independent statistics. For all zones and parameters not shown in table 10, parameters were held fixed at their initial values and not adjusted during the regression, effectively excluding them from the calibration procedure. Parameters were omitted from the calibration either because they had low css values indicating little influence on head or base-flow simulations made at observation sites, or had one or more high $p c c$ values that would indicate a strong correlation to parameters included in the regression and the potential for producing biased regression coefficients.

The final calibrated model produced a set of simulated water levels and stream base flows that were then compared to the mean observed water levels at the 34 wells and base-flow estimates at the four gaged sites (fig. 14, table 11). Plots of simulated and observed water levels and base flows indicate that simulated and observed values match closely, indicating that the dominant physical processes governing groundwater flow are largely accounted for and that little structural model error remains in the flow model. The root mean square errors for the unweighted residuals were $18.1 \mathrm{ft}$ and 384,924 cubic feet per day $\left(\mathrm{ft}^{3} / \mathrm{d}\right)$ for water levels and stream base flows, respectively. These errors are less than 5 percent of the range of values for water levels and less than 10 percent of the maximum stream base flow. Anomalously large errors are associated with two observations (L1.54V3, $65.56 \mathrm{ft}$, and L1.PGBc16, -45.51 ft). Both were observed in relatively shallow wells in moderate terrain and were assigned small weights due to their high degree of uncertainty. None of the 34 head or

Table 10. Final parameter values and fit-independent statistics.

[Parameter identifier, text title used in MODFLOW input file to label the parameter; Value, final calibrated parameter value (dimensionless); css, composite scaled sensitivity; $d s s$, dimensionless scaled sensitivity; observation names are provided in tables 7 and 8]

\begin{tabular}{ccccc}
\hline Parameter identifier & Value & css & $\begin{array}{c}\text { Largest dss for the } \\
\text { parameter }\end{array}$ & $\begin{array}{c}\text { Observation with } \\
\text { largest } \boldsymbol{d s s}\end{array}$ \\
\hline HK_11 & 58.05 & 8.59 & -29.80 & L1.ACAa6 \\
\hline HK_41 & 18.06 & 16.06 & -68.86 & L1.WECc3 \\
\hline HK_71 & 0.76 & 12.06 & -62.58 & L1.WWBc9 \\
\hline VK_61 & 5.34 & 3.14 & -13.40 & L7.WECa36 \\
\hline DRN_1 & 0.09 & 14.48 & -40.87 & F01649500 \\
\hline RCH_1 & 1.92 & 48.61 & 118.55 & L1.WWBc9 \\
\hline RCH_8 & 0.48 & 5.37 & 22.06 & L8.WWBa24 \\
\hline
\end{tabular}



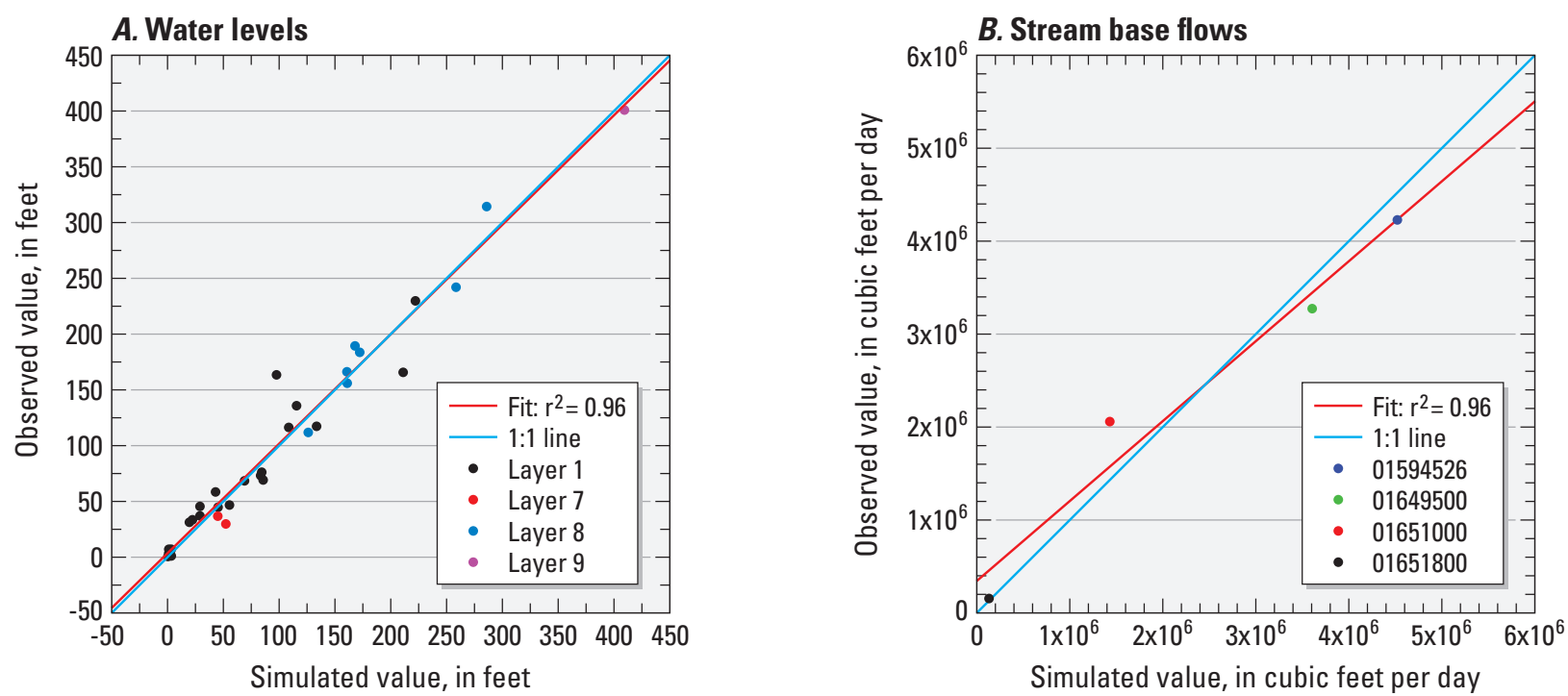

Figure 14. Simulated and observed values for the final calibrated model: $(A)$ water levels; $(B)$ stream base flows.

4 base-flow observations were excluded from the final regression (table 11).

Examination of the weighted residuals is of greater interest because one goal of parameter estimation using nonlinear regression is to produce weighted residuals that are wellbehaved, with a mean near zero, a minimal standard deviation, a distribution that can reasonably be considered normal, homoscedastic behavior characterized by a constant variance that does not depend on the magnitude of the observation, and negligible spatial bias. The weighted residuals for water-level and stream base-flow observations are given in table 11, and frequency distributions and empirical quantile-quantile plots are shown in figure 15. The empirical quantile-quantile plots demonstrate that the weighted residuals are nearly normally distributed. The distribution of the error in the simulated water-level observations does not show any obvious spatial bias in the residuals (fig. 16).

\section{Sensitivity Analysis Results}

The calibration procedure calculates a css (Hill, 1998; Hill and Tiedeman, 2007) (equation 15) for each parameter that is estimated. These sensitivities can be used in a comparative manner, in which larger values indicate parameters for which the observations provide more information. The calculated css for the seven parameters estimated in the calibrated model are shown in figure 17. Parameters not shown in figure 17 were not estimated and either had substantially smaller css values, or were excluded due to high correlation with another parameter. The highest css value is for the recharge rate to layer 1 ( $\left.\mathrm{RCH}_{-} 1\right)$. Many of the observations are in layer 1, including a large fraction of the four gaged basins and 24 of 34 observed water levels. The stream base flows were weighted heavily and therefore have large $d s s$ values (used in the calculation of $(s s)$; they provide more information than many of the other observations. For similar reasons, drain conductance in layer 1 (DRN_1) and the horizontal hydraulic conductivity for layer 1 (HK_11) have high css values.

The horizontal hydraulic conductivity for zone 41 in layer 4 (HK_41) has a relatively high css value because it is the subcrop for the upper Patapsco aquifer, and is directly beneath the surficial aquifer in the vicinity of the tidal Anacostia River (fig. 7). It is effectively controlling recharge to the deeper layers and is beneath or close to many of the layer 1 water-level observations. The model is also sensitive to the horizontal hydraulic conductivity for the Patuxent aquifer (HK_71, layer 7), because there are water-level observations in that layer and although it is generally confined, it is fairly shallow in its updip extent beneath Washington, D.C. (fig. 10). Finally, the vertical hydraulic conductivity for the lower Patapsco aquifer/ Arundel Clay (VK 61, layer 6), which is the least-sensitive parameter estimated, is an important control on flows between the surficial aquifer and the lower subcropping and confined units. It is especially important near the tidal Anacostia River, where both the Arundel Clay and lower Patapsco aquifer subcrop. The Arundel Clay may be very thin or absent in places (Ator and others, 2020), making it an important unit controlling the pattern and rate of groundwater discharge locally to the tidal Anacostia River. Considering that units that make up layers 4 through 7 may subcrop or outcrop locally within Washington, D.C., and therefore may be represented at the surface by hydrogeologic units in layer 1 (table 1, fig. 2), it is noteworthy that both HK_11 and VK_61 are significant parameters in the model.

Another way of evaluating the relative importance of different model parameters is by examining the degree of confidence in an estimated parameter value based on its 95-percent linear confidence interval. These intervals are calculated partly on the basis of the sensitivity of the parameter (Hill 
Table 11. Observed and simulated values for water levels and stream base flows, with calculated residuals, and weighted observed, simulated, and residual values.

[Observation name, text title given to observations in the UCODE_2005 and MODFLOW-NWT input files (names must begin with a letter); $\mathrm{ft}$, feet; $\mathrm{ft}^{3} / \mathrm{d}$, cubic feet per day; observed stream base-flow values are shown as negative quantities, as input into the model; residuals are equal to observed minus simulated values]

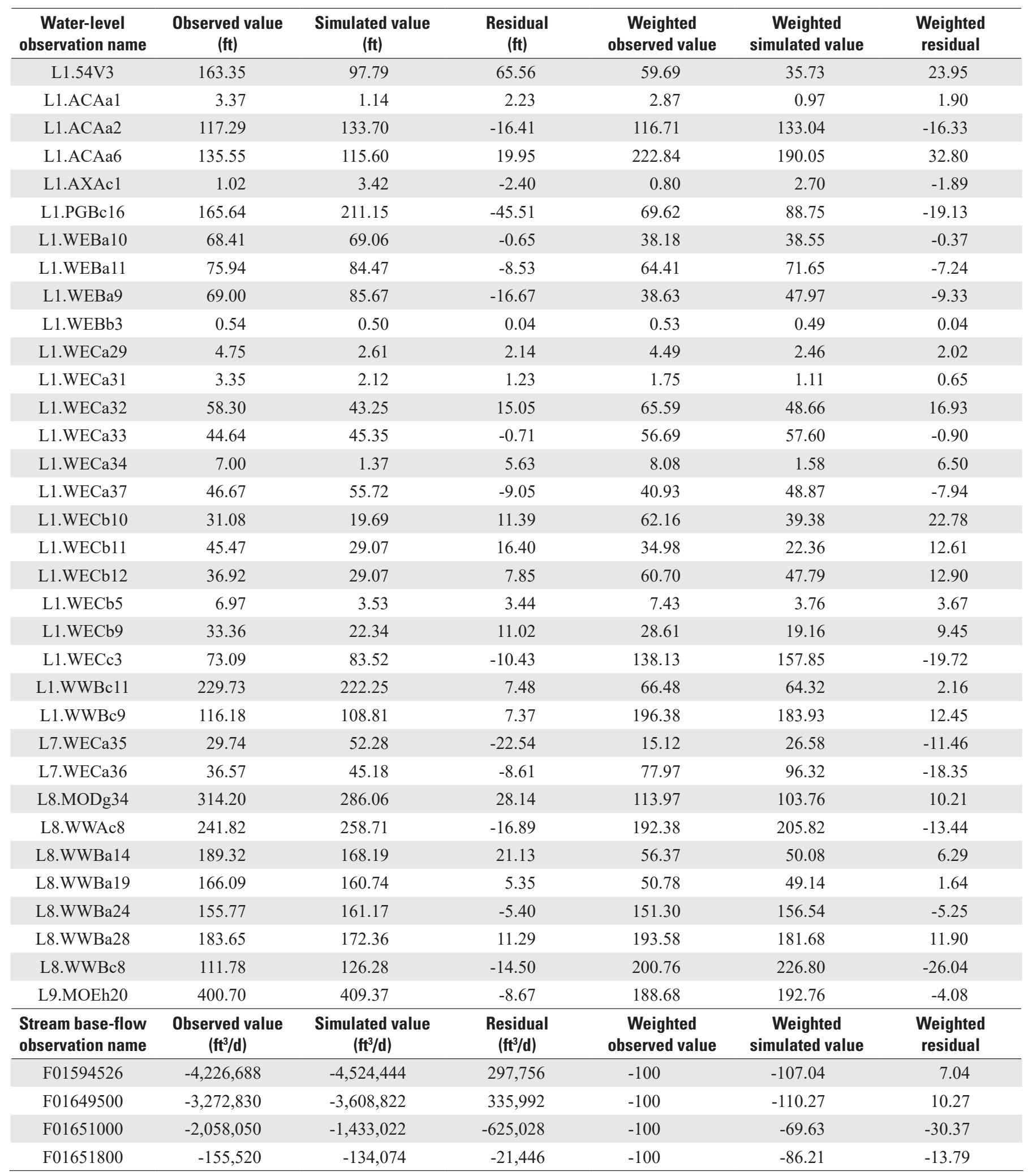



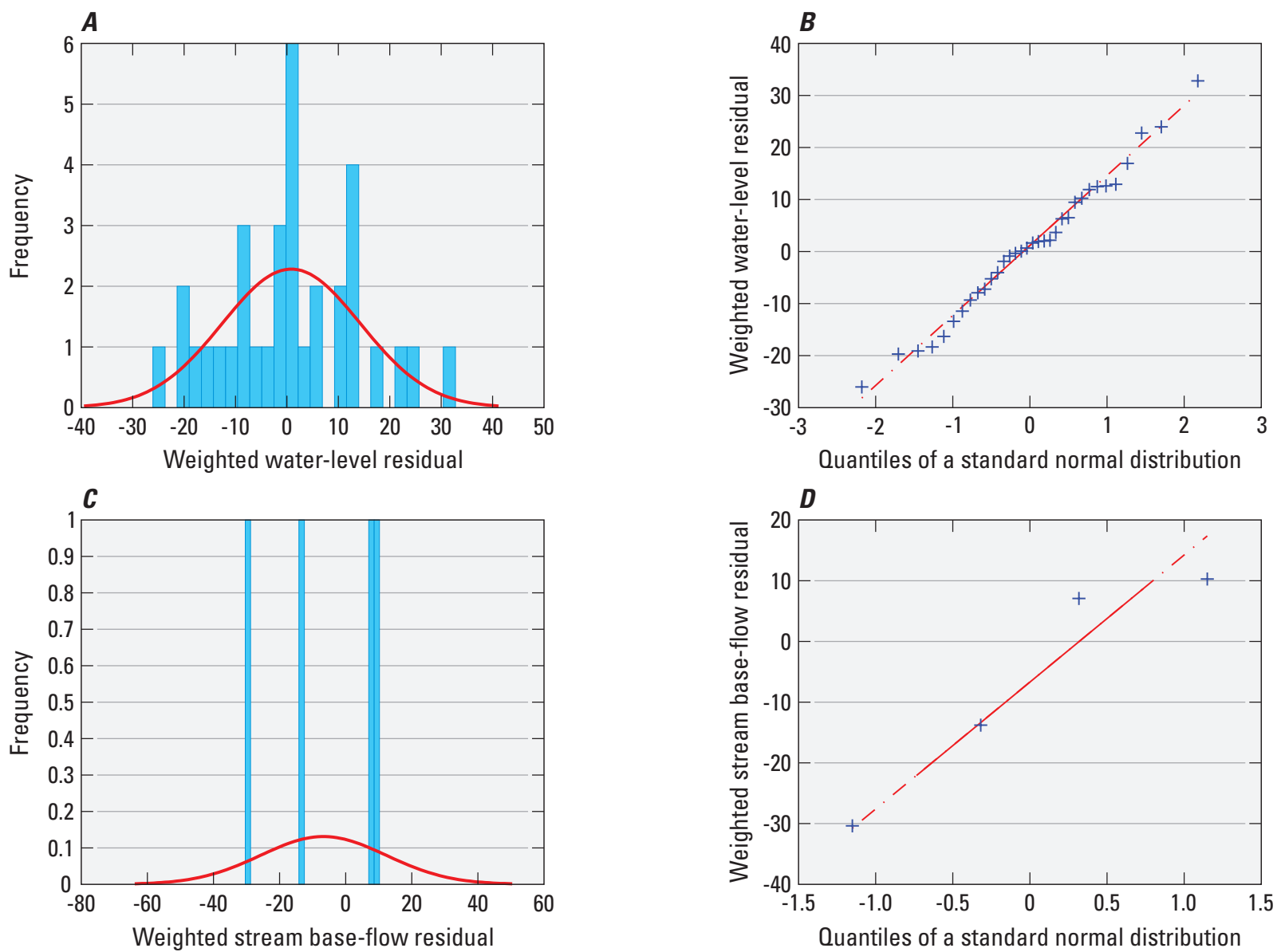

Figure 15. Frequency distribution and empirical quantile-quantile plots of weighted residuals for the final calibrated model: $(A)$ frequency distribution of weighted water-level residuals with fitted normal distribution; $(B)$ empirical quantilequantile plot of weighted water-level residuals; $(C)$ frequency distribution of weighted stream base-flow residuals with fitted normal distribution, and $(D)$ empirical quantile-quantile plot of weighted stream base-flow residuals.

and Tiedeman, 2007), and indicate a range of values within which the parameter value could be set and still give similar simulated values. The confidence intervals and coefficients of variation for the seven estimated parameters are given in table 12 . The parameters that were reliably estimated have relatively small confidence intervals and coefficients of variation.

Dss values can be used to compare the importance of different observations to the estimation of a single parameter. One important outcome of an analysis of $d s s$ values is that it provides useful information on the value of continued monitoring. A large $d s s$ value indicates an observation that provides substantial information in estimating one or more parameters (equation 14). Many of the observation wells used in calibration of the Anacostia model are part of an ongoing monitoring network. Although there may be other benefits to the monitoring, an assessment of $d s s$ values enables evaluation of wells that might not be providing valuable information for regional flow analysis. It may be beneficial in some instances to modify or discontinue monitoring at those sites in favor of monitoring other existing or new sites. Dss values for the 38 observations and seven estimated parameters are provided in table 13. Fifteen of those observations are shaded to indicate that their $d s s$ maximum absolute values were less than 10 percent of the largest maximum absolute value. Many have much smaller maximum values. The conclusion from this analysis is that there are a number of wells, some of which are currently being monitored, that do not provide important water-level information for this calibrated regional flow model. Observations with the largest absolute $d s s$ values provide significant information about parameters. These include water-level observations L1.WWBc9, L1.WECc3, L1.ACAa6, L1.ACAa2, L7.WECa36, and most base-flow observations.

There may be some benefit to continued monitoring at the wells with low $d s s$ values that is not readily apparent from this analysis of model sensitivity. For example, well MO Dg 34 is the only well in layer 8 near pumping wells and thus may be the only well in that area with data to elucidate drawdowns associated with pumping. Moreover, recent evaluations of data worth have focused on specific predictions rather than a more general calibration (Dausman and others, 2010; Fienen and 


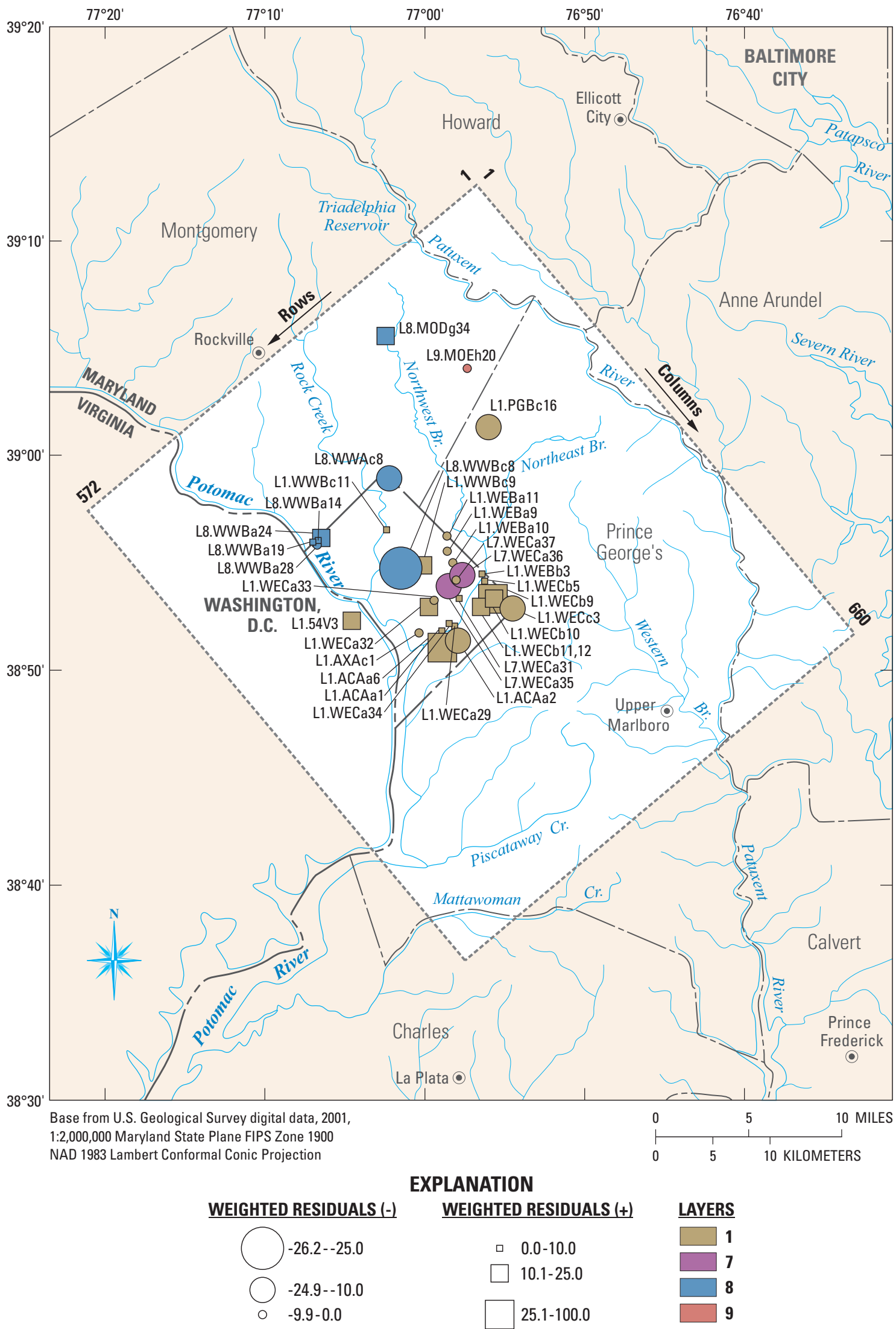

Figure 16. Magnitude and distribution of weighted residuals for observations of water levels in well. [Symbol type indicates residual sign, color indicates model layer, and size indicates relative magnitude.] 
others, 2010). Several of these wells have been sampled and the samples were analyzed geochemically, providing additional beneficial data (Klohe and Debrewer, 2007; Miller and Klohe, 2003). Finally, low $d s s$ values might be associated with the weight assigned to the observation at the well, and an alternative interpretation is that additional effort should be placed on improving the accuracy of the information on the well and measurements at the well in order to increase its weight (Paul Juckem, USGS, written commun., 2013).

\section{Simulated Water Table and Flow Patterns Near the Tidal Anacostia River}

A major result of the model and this study is a threedimensional distribution of groundwater levels that represent steady-state shallow groundwater conditions in the Anacostia watershed. The water table is simulated in model layer 1 and in the outcrop area of model layer 8 (zone 81 in figure 11). The simulated water table closely resembles the topography, especially in the Piedmont, where local flow systems dominate (fig. 18). Relief is greater in the Piedmont outcrop area than in the flatter Coastal Plain, which is reflected in the differences in the topography of the water table. Layer 1, with an area of $437.4 \mathrm{mi}^{2}$, has elevations ranging from 0 to $504 \mathrm{ft}$ and a mean of $150 \mathrm{ft}$; layer 8 (outcrop area, zone 81 ), with a smaller area of $113.4 \mathrm{mi}^{2}$, has elevations ranging from 3 to $562 \mathrm{ft}$ and a mean of $334 \mathrm{ft}$. The simulated water levels in model layers 2 through 8 (where they exist and have not pinched out) often mimic the water table near their updip limit where they may be very thin or subcrop beneath the surficial aquifer. However, as they thicken downdip and become confined, water levels become dominated by a regional southeast gradient induced by pumping (Curtin and others, 2012).

The simulated water table within Washington, D.C. (fig. 19) demonstrates the differences in water-table topography in the transition from Piedmont to the Coastal Plain. In northwestern Washington, D.C., the water-table elevation ranges from more than 350 to less than $100 \mathrm{ft}$ above sea level. In the Coastal Plain in southeastern Washington, D.C., the range of

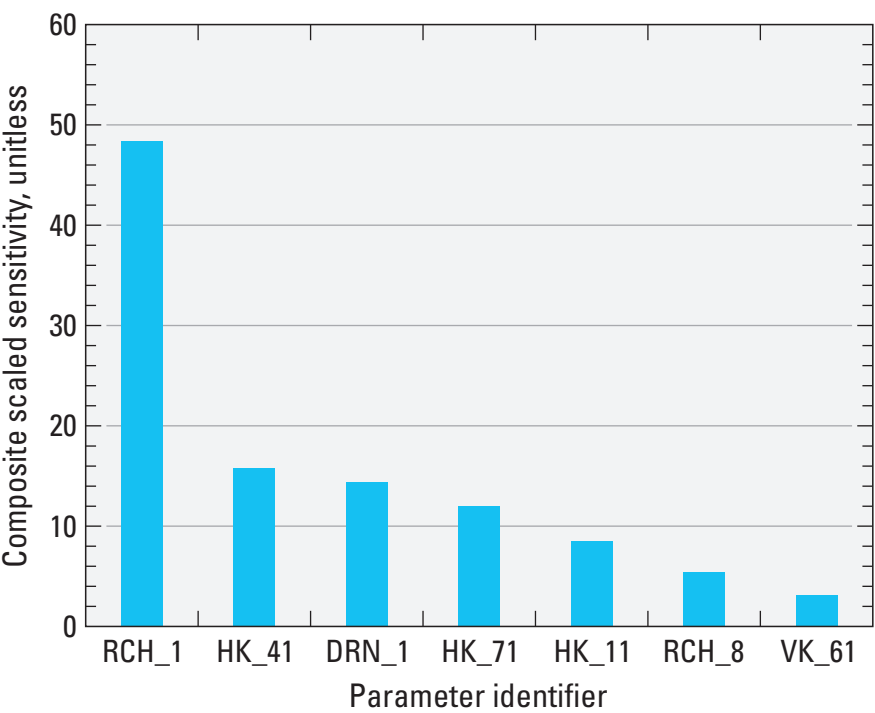

Figure 17. Composite scaled sensitivities (css) for the seven estimated model parameters.

heads is between 0 and $100 \mathrm{ft}$. Furthermore, the transition is characterized by heads decreasing to the southeast, indicating flow within the surficial aquifer from the Piedmont toward the tidal Anacostia River. Groundwater flow is predominantly toward the Potomac River and Rock Creek in northwestern Washington, D.C., and toward the Anacostia River in southeastern Washington, D.C. (fig. 19). Central Washington, D.C. has relatively little relief, which is reflected in the water table. In addition, flow diverges as the tidal Potomac is approached on the north side of the Anacostia River, indicating an increasingly important flow component toward the Tidal Basin and tidal Potomac River.

Aspects of the water table in the surficial aquifer can also be seen in three cross sections through the entire model (fig. 20). The location of the cross sections is shown in figure 19. These locations were selected on the basis of available information from cores related to the presence and absence of the Arundel Clay and other formations. Sections A-A' and

Table 12. Optimal values, confidence intervals, and coefficients of variation for the estimated model parameters.

[Parameter identifier, text title used in MODFLOW input file to label the parameter; --, the lower limit was calculated as being less than zero, which is consistent with the intervals being linear and the coefficient of variation being larger than 0.5 , but yields an unrealistic value]

\begin{tabular}{ccccc}
\hline Parameter identifier & Value & $\begin{array}{c}\text { Lower confidence } \\
\text { interval limit }\end{array}$ & $\begin{array}{c}\text { Upper confidence } \\
\text { interval limit }\end{array}$ & Coefficient of variation \\
\hline HK_11 & 58.05 & -- & 123.43 & 0.55 \\
\hline HK_41 & 18.06 & 6.50 & 29.62 & 0.31 \\
\hline HK_71 & 0.76 & 0.10 & 1.41 & 0.42 \\
\hline VK_61 & 5.34 & -- & 38.71 & 3.06 \\
\hline DRN_1 & 0.09 & 0.05 & 0.12 & 0.20 \\
RCH_1 & 1.92 & 1.44 & 2.40 & 0.12 \\
\hline RCH_8 & 0.48 & 0.01 & 0.95 & 0.48 \\
\hline
\end{tabular}


Table 13. Dimensionless scaled sensitivity $(d s s)$ values for all observations for the seven estimated model parameters, with maximum absolute values for both parameters and observations. Water-level observations in shaded rows have maximum dss absolute values smaller than 10 percent of the greatest maximum (118.55) and are therefore providing relatively little information in support of model parameter estimates.

[WL, water level; BF, base flow; parameter names are defined in table 9; |Max $\mid$, maximum absolute value]

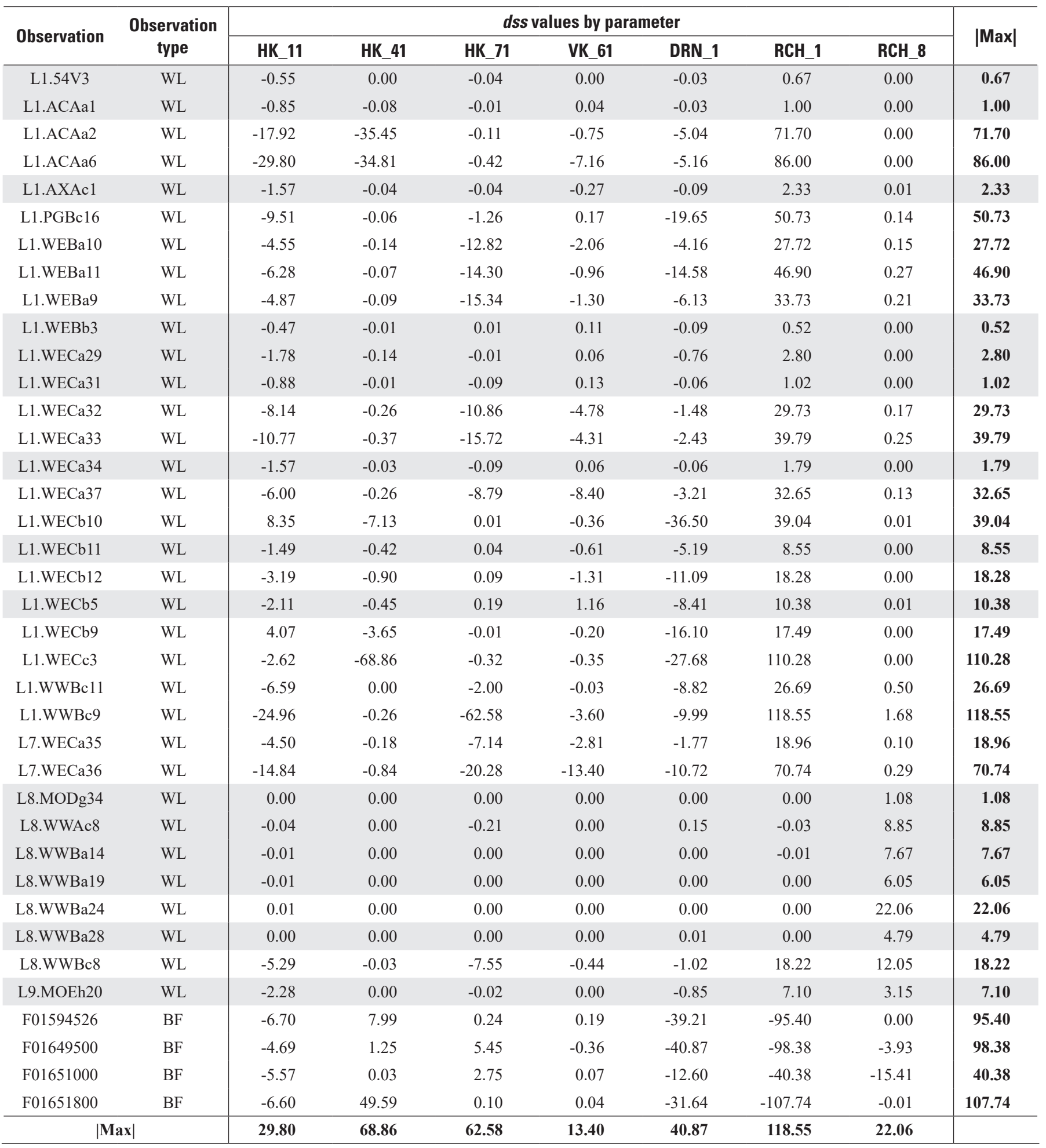




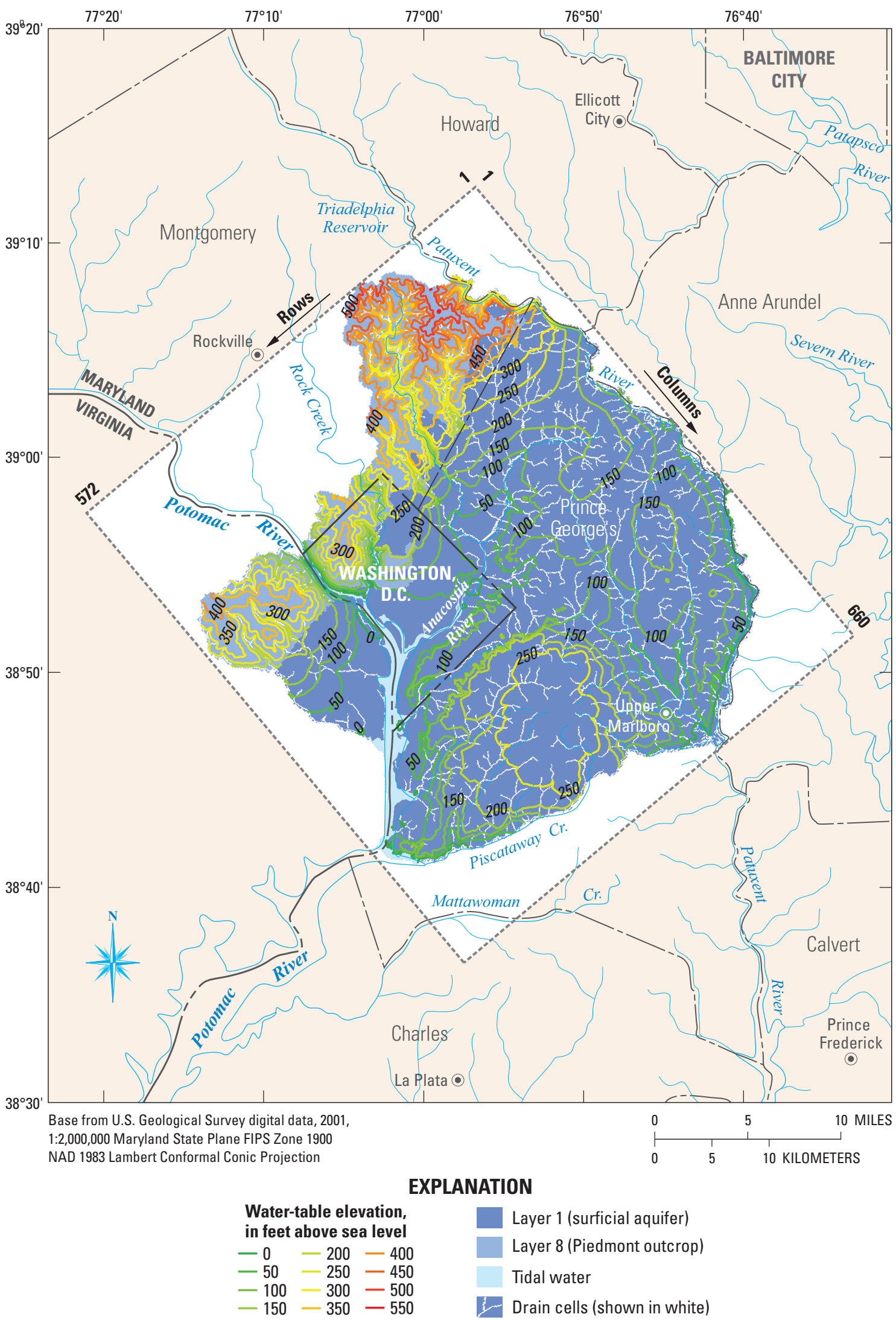

Figure 18. The simulated water table for the model domain represented by water levels in layer 1 (surficial aquifer) and the outcrop area of layer 8 (Piedmont weathered rocks). 


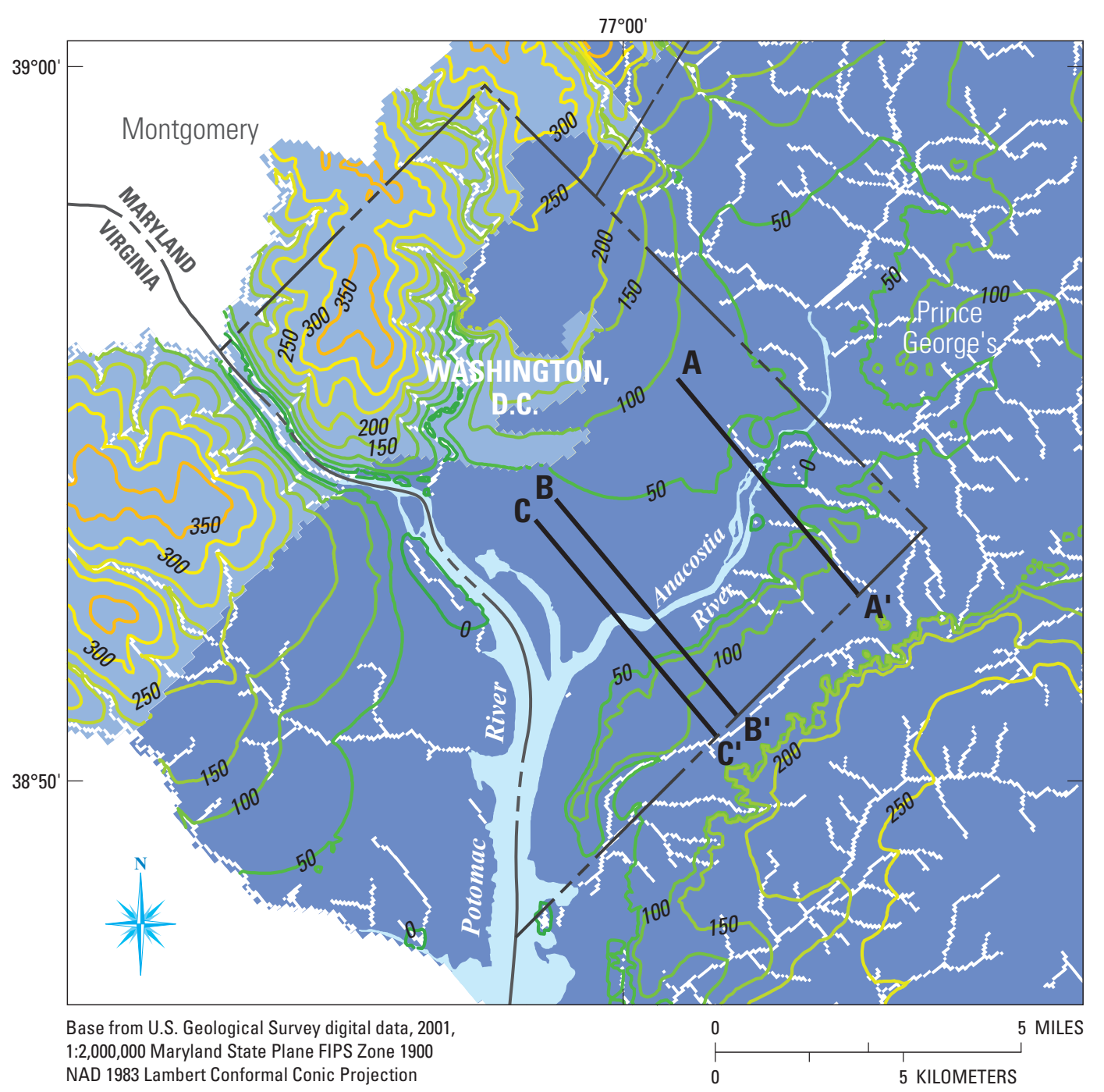

EXPLANATION

$\begin{gathered}\text { Water-table elevation, } \\ \text { in feet above sea level }\end{gathered}$
$-0 \quad-200$
$-50-250$
$-100-300$
$-150-350$

Layer 1 (surficial aquifer)

Layer 8 (Piedmont outcrop)

$\mathbf{A} \longrightarrow \mathbf{A}^{\prime}$ Line of section A-A'

(Refer to figure 20)

Tidal water

Drain cells (shown in white)

Figure 19. The simulated water table for Washington, D.C. represented by water levels in layer 1 (surficial aquifer) and the outcrop area of layer 8 (Piedmont weathered rocks).

B-B' correspond approximately with the similarly designated cross sections of Ator and others (2020). The Arundel Clay, combined with the lower Patapsco aquifer in model layer 6 , is thought to be an important hydrogeologic unit in this area and is known from cores to be absent in parts of central Washington, D.C. (Ator and others, 2020). Colors indicate the magnitude of the calibrated horizontal hydraulic conductivity, and can be used to discern the different model layers. In the cross sections, it is evident that layer 6 is tens of feet thick in northeastern Washington, D.C., but thins to almost zero beneath the river in section C-C'. In all three sections, flow is from the northwest and southeast toward the river. However, the gradients toward the river, both lateral and vertical, decrease from section A-A' to section C-C'. This is due in part to the changing thickness of the Arundel Clay and to changes in the relief of the land surface and water table near the tidal Anacostia River. Vertical gradients, particularly, are greater in the northeast, where the relief is greatest and the Arundel clay thicker. Flow paths from the north are largely horizontal through the surficial aquifer and relatively permeable Patuxent aquifer. From the south, the flow paths toward the river largely originate in the elevated topographic areas southeast of the 

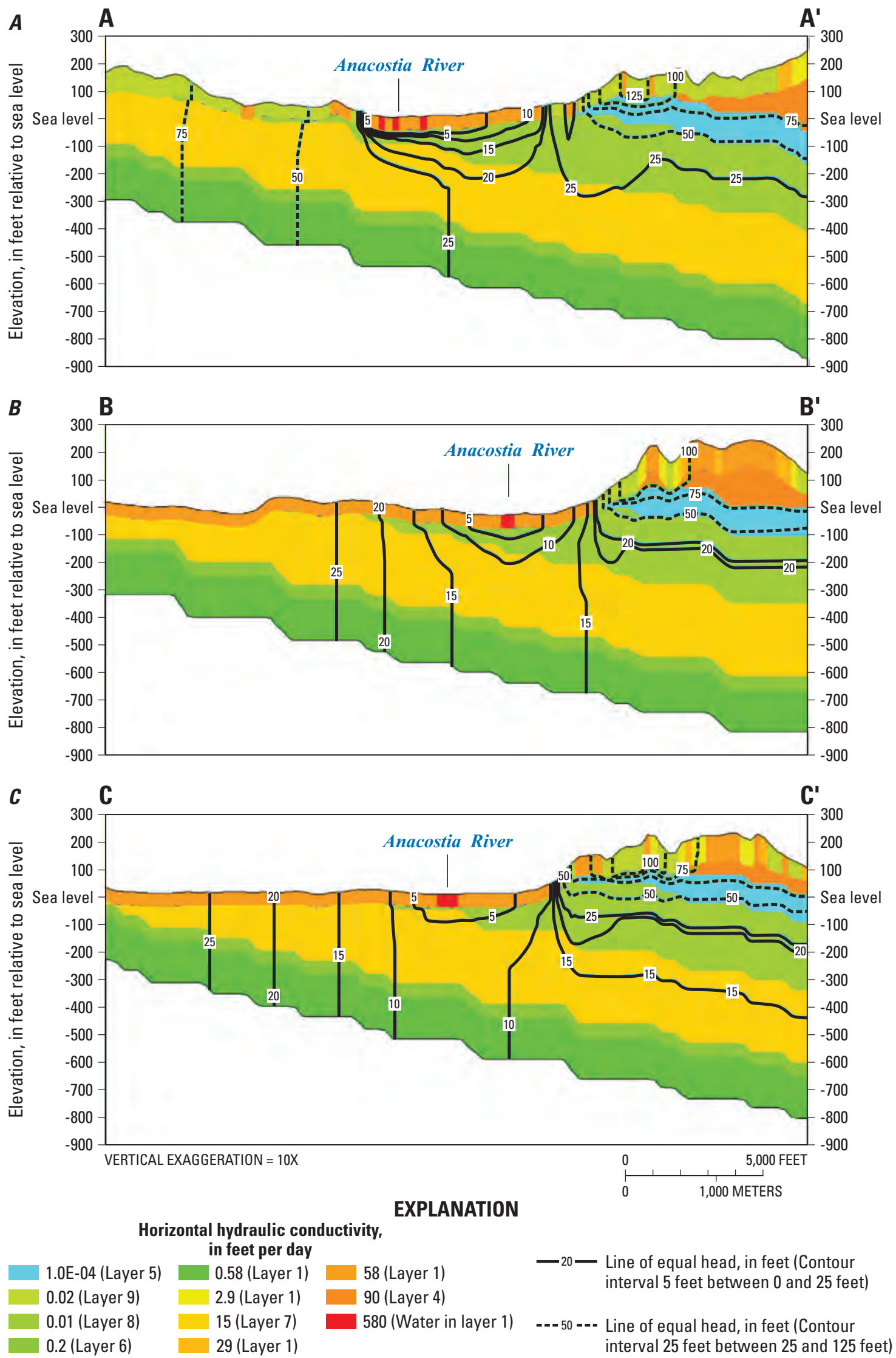

Figure 20. Calibrated horizontal hydraulic conductivity and simulation results for heads in cross sections $(A)$ $A-A^{\prime},(B) B-B^{\prime}$, and $(C) C-C^{\prime}$. (Refer to figure 19 for cross section locations.) 
river and pass through the surficial aquifer and model layers 5 (Patapsco confining unit), 6 (lower Patapsco aquifer/Arundel Clay), and to some extent, 7 (Patuxent aquifer).

\section{Groundwater Flow to the Tidal Rivers}

A major goal of this study was to quantify the rate and pattern of groundwater flow to the tidal Anacostia River. The patterns of flow have been described in the previous section. Base flow to the tidal rivers in and around Washington, D.C. can be evaluated by examining fluxes to the constant-head cells in model layer 1. Fluxes calculated by MODFLOWNWT are output with a sign that indicates whether the flux is a gain (positive) or a loss (negative) relative to the groundwater system (fig. 21). Therefore, negative fluxes represent discharge to the tidal river (or loss from the groundwater system) and positive fluxes represent recharge to the groundwater system from the tidal river. Fluxes are presented in units of $\mathrm{ft}^{3} / \mathrm{d}$; all cells are 250 by $250 \mathrm{ft}$ in plan view. Relatively small fluxes, regardless of sign, are mapped together because model error, including discretization error and errors resulting from the assumption that tidal water levels are constant at zero makes it difficult to distinguish flux direction. Discharge to the tidal rivers is shown in cool (blue) colors and losses from the tidal rivers to the groundwater system are shown in warm (red) colors.

Groundwater flow to and from the tidal rivers is generally greatest near the land-water boundary, where the gradient in the water table is steepest, and diminishes toward the middle of the tidal rivers (Bratton, 2010). The tidal rivers are

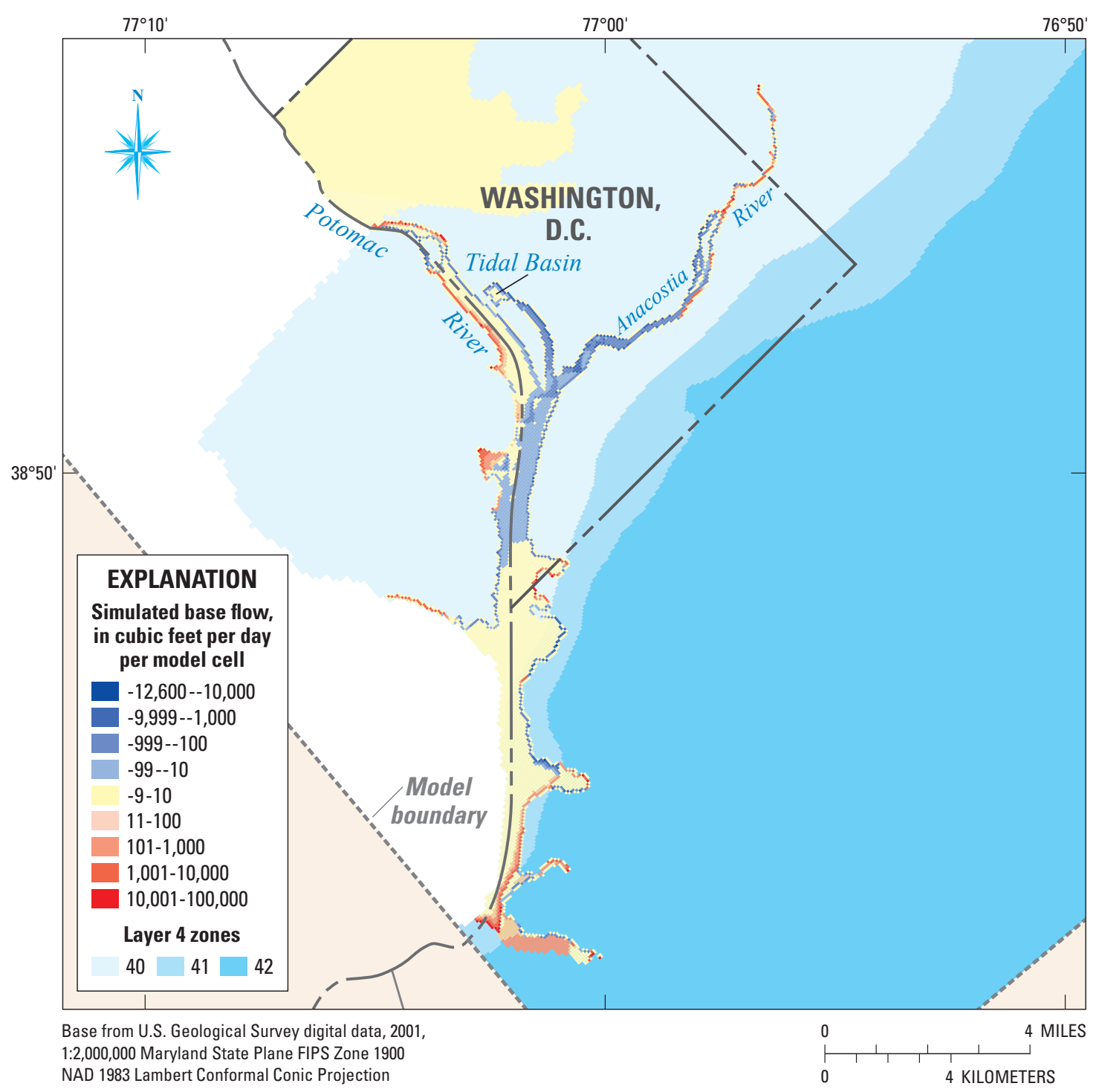

Figure 21. Simulated base flow to constant-head cells representing tidal rivers in the model. 
predominantly areas of groundwater discharge, although there are areas where tidal waters are recharging the subsurface, typically where small variations or depressions in the topography produce small locally reversed gradients in the water table. However, recharge of tidal waters to the groundwater system is observed for the tidal Potomac River where the upper Patapsco aquifer subcrops south of Washington, D.C. (zone 41 of model layer 4, fig. 21). This is consistent with a recent study of groundwater ages and geochemistry in the upper Patapsco aquifer, which concluded that recharge from the Potomac River to the aquifer was important (Plummer and others, 2012).

The tidal Anacostia River, tidal Potomac River, and Tidal Basin in Washington, D.C. are generally areas of groundwater discharge (fig. 22). These fluxes may be moderately large-a flux of $1,000 \mathrm{ft}^{3} /$ day, when normalized by the plan view area of a single model cell, is equal to a flow rate of 70 inches per year (in/yr). For comparison, recharge rates in the model are 0.5-23 in/yr. However, there are areas where tidal waters are recharging the groundwater system. Examples include areas on the southwest side of the tidal Potomac River in and south of Washington, D.C., where the relief is less and the elevations lower, and in parts of the tidal Anacostia River in northeast Washington, D.C.

For several reasons, the positive fluxes simulated for the Anacostia River in northeast Washington, D.C. must be viewed with some caution. Model uncertainty leads to limitations, which will be discussed in greater detail later. The model cells are 250 by $250 \mathrm{ft}$ and each cell is assigned a single elevation and has a single simulated water level. Smaller features

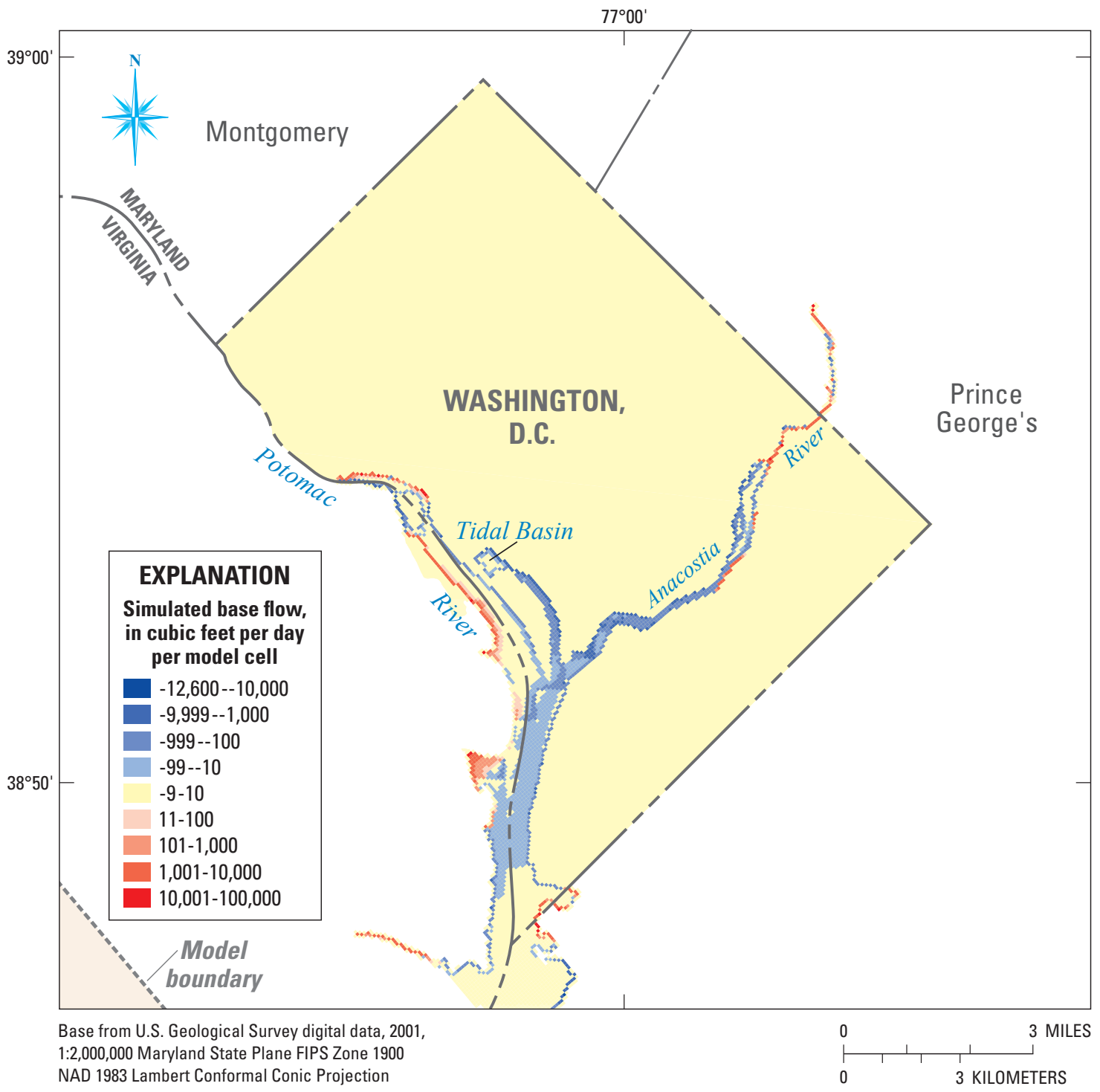

Figure 22. Simulated base flow to constant-head cells representing tidal rivers in Washington, D.C. 
(stream incisions, small hillslopes, riparian wetlands, stream braiding, anthropogenic features related to land development and infrastructure that affects shallow groundwater) may not be adequately represented without refining the model grid substantially. The Anacostia River in northeast Washington, D.C. is relatively narrow (100 ft or less) and becomes hydrologically complex between East Capitol Street near RFK Stadium and Kenilworth Aquatic Gardens near the Washington, D.C.Maryland border. The model cells exhibiting positive fluxes are located in this area, where the tidal Anacostia River may be represented in cross section by only one or two model cells at most. Examination of the simulated water levels adjacent to these cells reveals very small gradients in hydraulic head, indicating that minor adjustments in model hydraulic parameters might have a large impact. A model that refines the discretization in both the vertical and the horizontal dimensions in this area and allows for multiple hydraulic conductivity parameters rather than a single parameter could help resolve errors associated with uncertain base-flow estimates along the tidal rivers. Use of information from previous studies (Fienen and others, 2013; Hill and others, 1998; Hill and Tiedeman, 2007) might provide an improved prediction of fluxes to and from the tidal Anacostia River in northeast Washington, D.C.

\section{Regional Water Budget}

Insight into the regional groundwater-flow system may be gained by examining the overall water budget, which is calculated for each budget component by MODFLOW-NWT (table 14). Total recharge is the largest input to the regional groundwater system, with 89 percent of the total inflow. Flows from tidal waters and boundaries modeled as constant-head boundaries provide the remaining 11 percent of inflows. Outflow is mostly modeled to streams and rivers as drains (56 percent), followed by evapotranspiration ( 21 percent) and to tidal waters and boundaries modeled as constant-head cells (22 percent). Less than 1 percent of outflow is due to withdrawal from pumping wells.

A large part of the outflow to constant-head boundaries is to tidal waters from the surficial Coastal Plain aquifer. Net recharge is calculated as the difference between total recharge and evapotranspiration. When normalized by the area of the surficial aquifer (layer 1 and the outcrop area of layer 8), the calculated average net recharge rate of $10 \mathrm{in} / \mathrm{yr}$ is similar to that estimated by Fleck and Vroblesky (1996) and Cushing and others (1973) for the Coastal Plain. The net recharge rate is higher for the Coastal Plain surficial aquifer than for the Piedmont, because base-flow observations (which have high $d s s$ values and thus dominate parameter estimation in the model) for the predominantly Piedmont Northwest Branch Anacostia River are lower than those for the Coastal Plain rivers (see fig. 13 and table 8). Sanford and others (2012) estimated net recharge (when normalized by area) for the Northwest Branch to be 68 percent of the Northeast Branch recharge rate, demonstrating that small quantities of net recharge are required to support low base flows in streams draining the Piedmont and larger net recharge is needed to sustain higher base flows in streams draining Coastal Plain deposits. Logan (1999) also found that net recharge rates for a model that included the Piedmont were lower than estimates for the Coastal Plain.

Table 14. Water budget computed by the calibrated steady-state model, Anacostia River and surrounding watersheds.

$\left[\mathrm{ft}^{3} / \mathrm{d}\right.$, cubic feet per day; in/yr, inches per year, calculated from the flow in $\mathrm{ft}^{3} / \mathrm{d}$ divided by the total surficial area of layer 1 and the outcrop area of layer 8 $\left(550.75 \mathrm{mi}^{2}\right.$ or $\left.1.535 \times 10^{10} \mathrm{ft}^{2}\right) ; \%$, percent; $<$, less than]

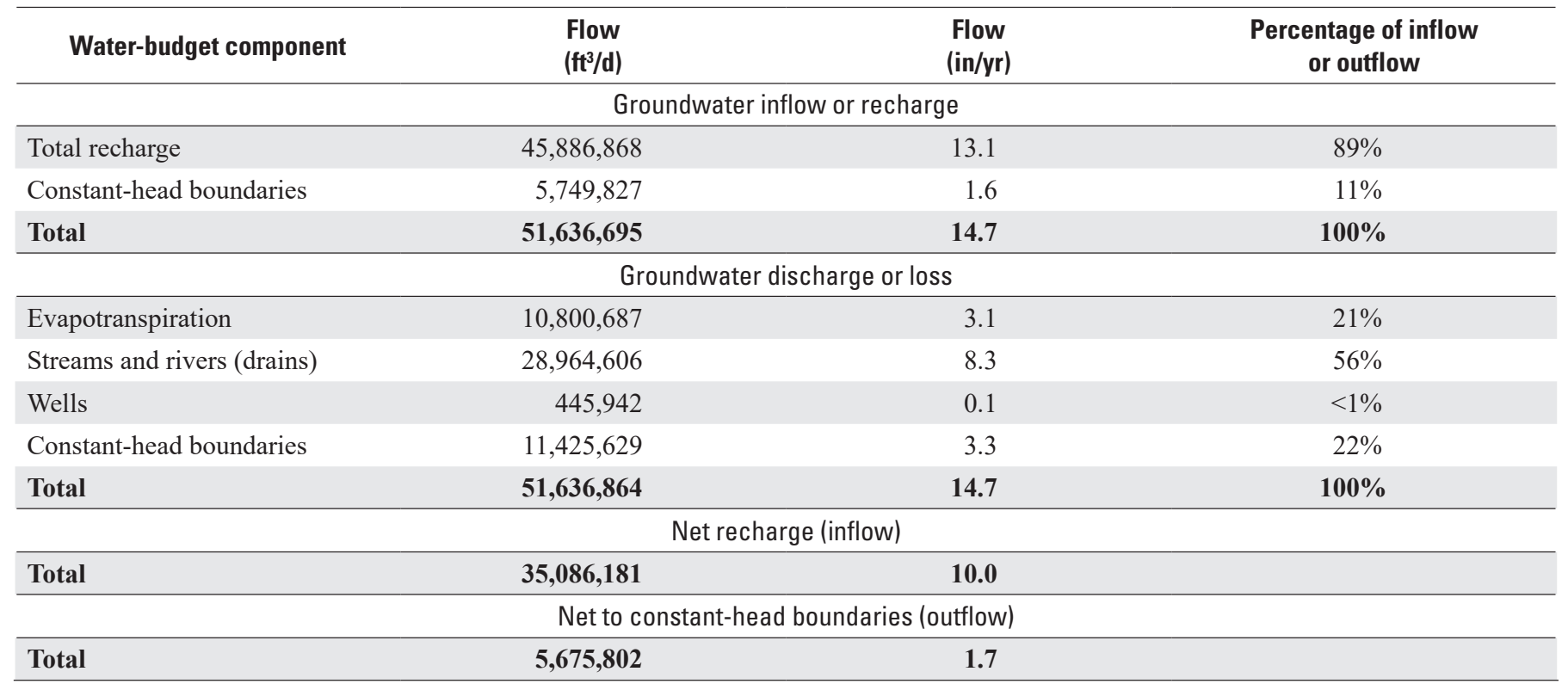


Flow into the surficial groundwater system of Washington, D.C. is predominantly from recharge, although an additional 16 percent of the total inflow is from crystalline bedrock in the Piedmont or from Coastal Plain aquifers beneath the surficial aquifer. Relatively little inflow or outflow is from or to the area outside of Washington, D.C. The outflows are mainly to the lower model layers representing crystalline bedrock and Coastal Plain aquifers (34 percent), to nontidal streams within Washington, D.C. (28 percent), to the tidal Anacostia River (14 percent), to evapotranspiration (10 percent), and to other tidal waters or outside of Washington, D.C. (table 15).

In this report, the budget terms for each zone designation refer strictly to the groundwater system. For example, considering the tidal Potomac River, 44 percent of the inflows to the groundwater system are from constant-head cells associated with tidal surface water; similarly, 54 percent of the outflows from the groundwater system are to tidal surface water (table 15). For the Tidal Basin and the adjacent part of the tidal Potomac River (fig. 23), most of the inflows to the groundwater system are from Washington, D.C. (63 percent) or from deeper crystalline bedrock and Coastal Plain aquifers (32 percent); 98 percent of groundwater discharge is to tidal surface water.

Inflows to the groundwater system directly beneath the tidal Anacostia River are predominantly from adjacent land areas within Washington, D.C. (55 percent of total inflows), followed by tidal surface water ( 24 percent of total inflows; see fig. 22) and from deeper crystalline bedrock and Coastal Plain aquifers (16 percent of total inflows). For the tidal Anacostia River budget zone, as shown in figure 23, the deeper Coastal Plain aquifers are mainly the subcrop areas of the lower Patapsco aquifer and Arundel Clay (layer 6, fig. 9) and the Patuxent aquifer (fig. 10). Outflows from the groundwater

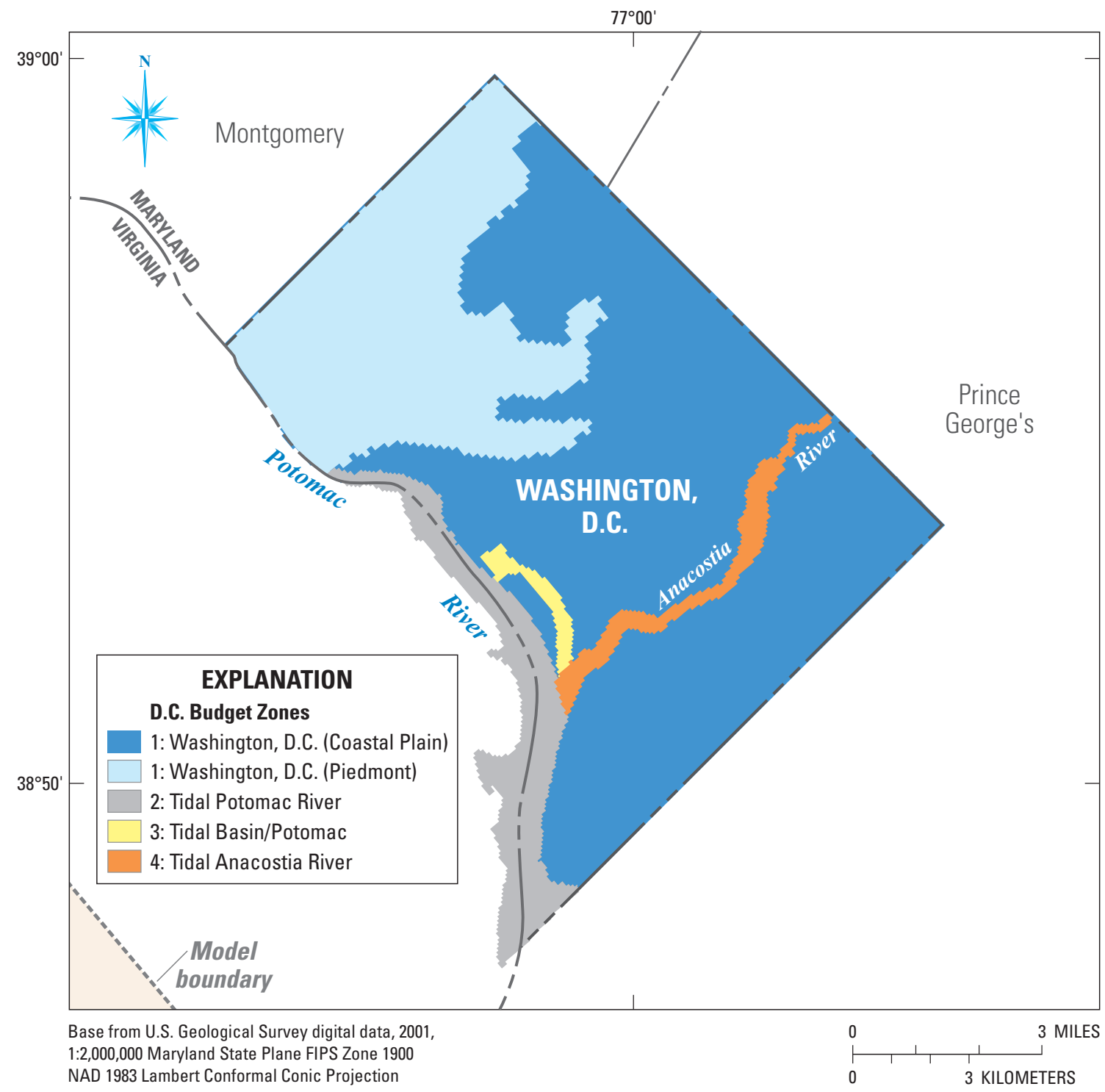

Figure 23. Zones created for Washington, D.C. and tidal waters within Washington, D.C. 
Table 15. Water budget for the groundwater system computed by the calibrated steady-state model for Washington, D.C., including tidal waters.

[D.C. zone, zones shown in figure 23; from/to outside of D.C., flows into or out of a zone from or to the area surrounding Washington, D.C.; ET, evapotranspiration; net flow is calculated as inflows minus outflows; \%, percent]

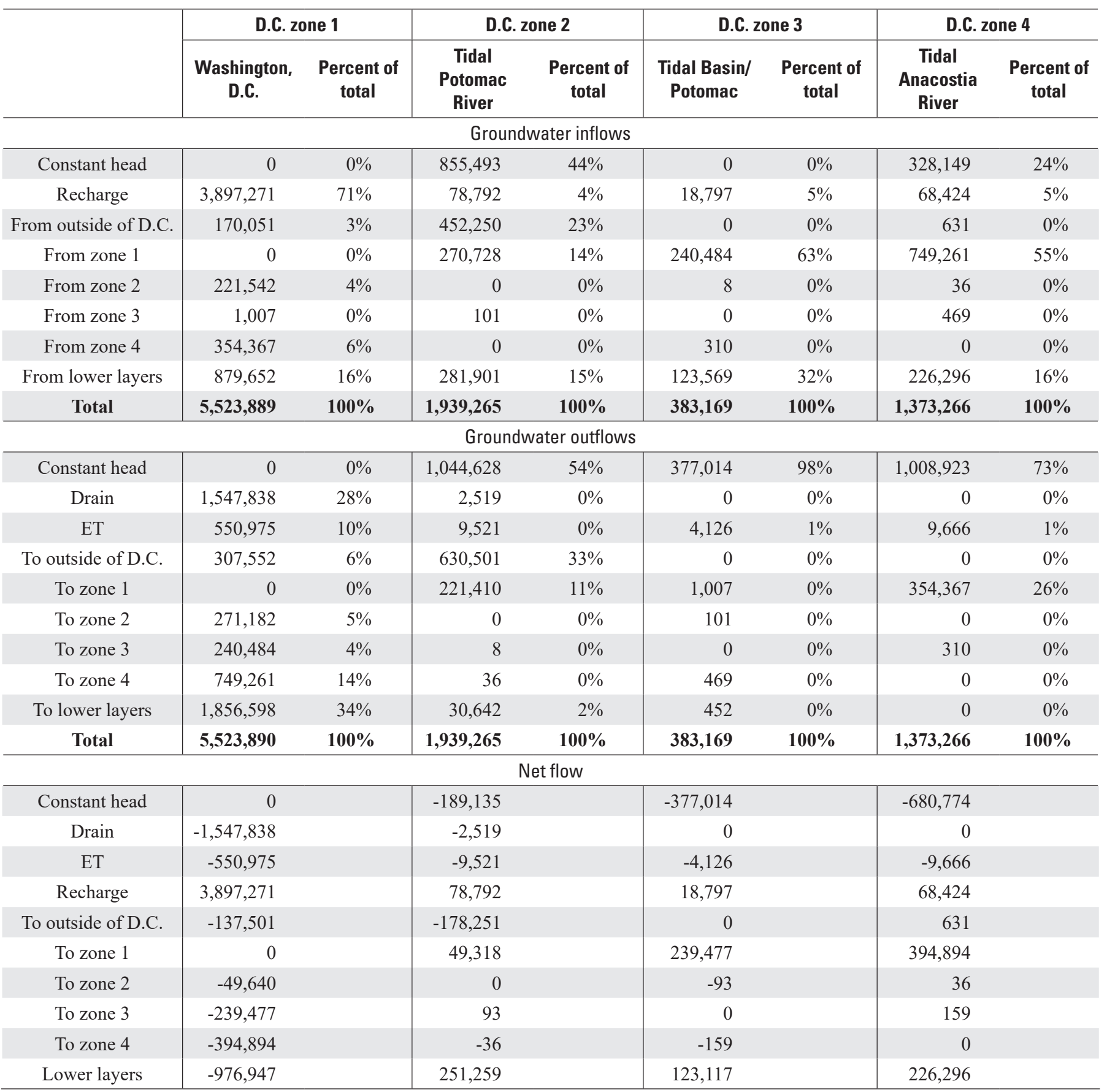


system are largely to the tidal Anacostia River (73 percent of total outflows), with a smaller part going to Washington, D.C. (26 percent of total outflows). These budget quantities are consistent with the patterns of flow shown in the cross sections in figure 20 and with the patterns of gains and losses from tidal water (fig. 22).

Considering only net flows for the groundwater system beneath the tidal Anacostia River within Washington, D.C. (fig. 24), almost all of the net groundwater discharge is to the tidal Anacostia River, with a very small amount lost as evapotranspiration from small islands within the Anacostia River that were included in the zone for the purpose of budget calculation. The source of this water is mainly adjacent to Washington D.C. (57 percent), from deeper Coastal Plain aquifers in the area (33 percent), and from recharge directly to the small land areas within the river (10 percent).

\section{Model Limitations and Suggestions for Additional Work}

The goal of this modeling study was to develop a regional groundwater-flow model capable of being accurate at scales relevant to current and future studies regarding groundwater-flow contributions to the tidal Anacostia River.
A groundwater-flow model is a method for simulating and testing a conceptual understanding of a real system. Because groundwater-flow systems are inherently complex, simplifying assumptions were made in developing this model (Anderson and Woessner, 1992). Models solve for average conditions within each cell, the parameters for which are interpolated or extrapolated from measurements and (or) estimated during calibration. In light of this, the intent in developing the groundwater-flow model for the Anacostia River and surrounding watersheds was not to reproduce every detail of the natural system, but rather to portray its general characteristics.

All models are based on a limited amount of data and are therefore simplifications of the actual system. Model limitations result from uncertainty in four aspects of the model, including inadequacies or inaccuracies in (1) conceptualization of the flow system; (2) model discretization and heterogeneity; (3) the method or methods used to estimate model parameters, sensitivity, and uncertainty; and (4) observations used to calibrate the model. It is important to understand how these uncertainties limit the use of the model.

The accuracy of a groundwater-flow model depends on the accuracy of the conceptual model. The following simplifications were invoked to make the problem tractable, given available data:

\section{A. Net flows out of the groundwater system for the tidal Anacostia River}

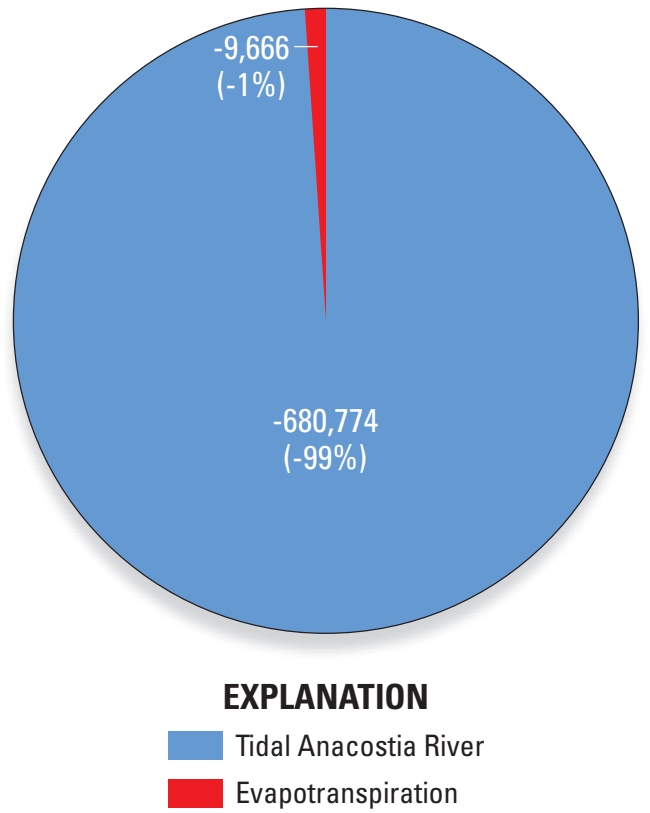

\section{$B$. Net flows into the groundwater system for the tidal Anacostia River}

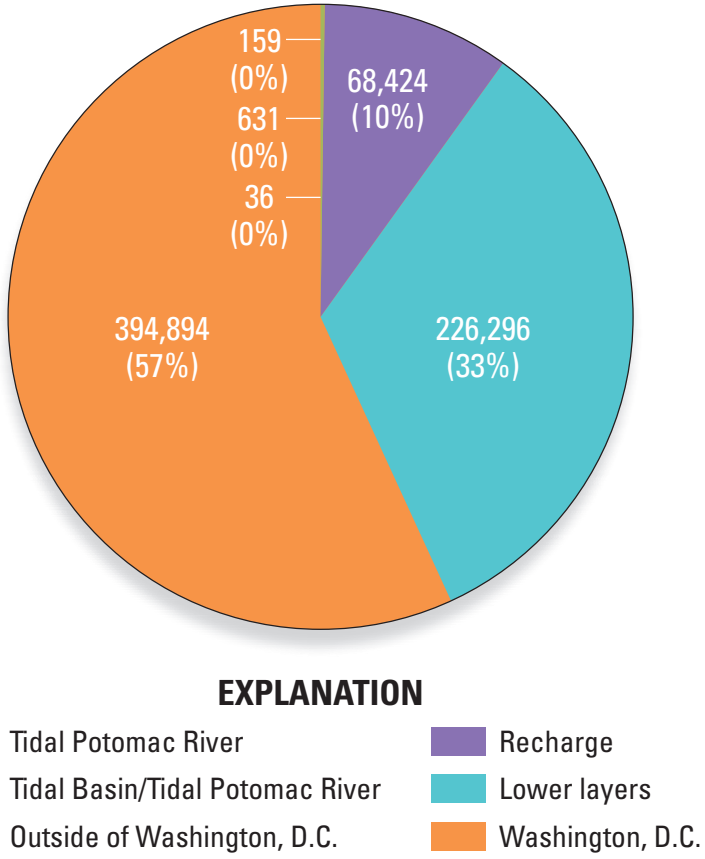

Figure 24. Pie charts of the $(A)$ outflows and $(B)$ inflows of groundwater computed by the calibrated steady-state model for the Anacostia River. [Numbers are flows in cubic feet per day, and numbers in parentheses are percentages of the total net inflow or outflow. Refer to table 15.] 
1. The system was modeled as being at steady state, or as representing a long-term average condition, neglecting transient influences such as daily tides, the seasonality of recharge and other stresses, and short-term effects such as pumping.

2. The model is regional in its extent, in order to avoid problems with arbitrary boundary conditions and to make the best use of natural boundary conditions, as well as take advantage of observations and other information available only at a regional scale.

3. Although the model is regional, the location and type of some boundaries for certain model layers are uncertain and present an additional limitation, especially in the downdip areas of the confined aquifers where constant-head boundaries are used based on potentiometric-surface maps from Soeder and others (2007).

4. Net recharge is modeled as the difference between recharge (spatially variable based on land cover and geology) and evapotranspiration (similarly spatially variable, but with an extinction depth). There are no direct measurements of net recharge and the model calibration relies on estimates of stream base flow from Sanford and others (2012) and Logan (1999), as well as base flow estimated at four gaged basins within the model domain. Future improvements to the model might include application of the Soil-WaterBalance (SWB) model (Westenbroek and others, 2010) to provide better estimates of the recharge rates. The Unsaturated-Zone Flow (UZF) package (Niswonger and others, 2006) might also be used in place of the recharge and evapotranspiration packages to improve simulation of the water table (Paul Juckem, USGS, written commun., 2013).

5. All streams and rivers are modeled using the drain (DRN) package of MODFLOW-NWT, which does not account for the possibility of losing stream reaches. A future improvement to the model might involve substitution of the Surface-Water Routing Process (SWR) (Hughes and others, 2012) for the relatively simple drain package. This might also help resolve issues related to the topography of the land surface and tidal water elevations for the tidal Anacostia River in northeast Washington, D.C.

6 . The conceptual model does not explicitly account for anthropogenic sources and sinks, such as leaking infrastructure. Total recharge is considered to include unreported pumping (a negative recharge), gains and losses from leaking infrastructure, sumps, and other poorly known anthropogenic sources and sinks.

7. A constant-head boundary (zero ft above sea level) was applied to all cells in layer 1 associated with tidal water. No effort was made to vary the mean tide level or incorporate transient tidal effects.

A necessary simplification of the physical system in groundwater-flow models involves spatial discretization and the representation of physical heterogeneity in aquifer properties. The MODFLOW-NWT model discretization (cell width) is $250 \mathrm{ft}$ by $250 \mathrm{ft}$. As a result of this discretization, the hydraulic properties and simulated water levels within each cell are reduced to one average value for the entire cell. Although this cell size is adequate for the simulation objectives described in this report, the model might benefit from finer spatial resolution, particularly near rivers where simulated losses and gains to and from the underlying surficial aquifers are of interest.

In addition to structural model errors and discretization errors, errors related to the collection of aquifer characteristics at various spatial scales have likely introduced significant sources of error to the model; for all practical purposes, these cannot be quantified. The hydrogeologic framework and initial hydraulic property estimates are derived from multiple sources, each with their own characteristic spatial scale and uncertainty. The hydrogeologic framework is based on the one published for the Coastal Plain by the Maryland Geological Survey (Andreasen and others, 2013), with simplifying assumptions of uniform thickness for the basement layers. The Coastal Plain hydrogeologic framework has a spatial resolution of 3,500 ft. Multiple sources of information were assembled to create the geologic map for layer 1, each with different resolutions and unit naming conventions. Layers 2 through 9 were modeled as being homogeneous because of a lack of prior information and observations. Each of these sources of scale-related uncertainty has introduced errors of unknown magnitude into the model that have the potential to produce inaccurate water-level and base-flow predictions.

Additional limitations result from the method used to estimate model parameters, sensitivity, and uncertainty (Fienen and others, 2010; Hill, 1998; Hill and Tiedeman, 2007; Poeter and others, 2005). Parameter estimation and sensitivity analysis rely heavily on observations. Prior information was used only indirectly, as a guide in establishing initial parameter values, especially for parameters that were not estimated by regression.

Observations of hydraulic head (water level) and stream base flow constrain model calibration through parameter estimation, and their level of accuracy creates additional uncertainty affecting model limitations. The quality of the waterlevel observations was used directly in error-based weighting of the regression, but the errors were composed of multiple components, some of which were estimates. Spatial clustering of observations and the lack of water-level observations from several model layers adversely impacted parameter estimation and provided an additional source of uncertainty that limits model applicability. Many water-level observations are from the surficial aquifer (model layers 1 and the outcrop area of layer 8), where perched conditions may exist that were not simulated. In addition, the surficial system in the urban setting 
of Washington, D.C. includes anthropogenic flows that are not accounted for in the model. Stream base flow was estimated using hydrograph-separation techniques that have an associated uncertainty; their weighting was unrelated to measurable accuracy but was driven by subjective decisions regarding data value.

Another major limitation of a regression-based calibration approach includes potential nonlinearities in the error surface defined by the sum of squared, weighted residuals that can cause the regression to converge to a sub-optimal parameter set. Extreme nonlinearity can produce a model that simulates inaccurate water levels and base flows. To test for nonlinearity, multiple regressions should be run using different initial parameter sets to determine if the model converges to the same optimal set of parameters. Subjective use of prior information as a guide in establishing initial parameter values for adjustable parameters can help mitigate problems associated with extreme model nonlinearity and the non-unique parameter sets that it can generate.

The performance, utility, detail, and accuracy of the Anacostia River groundwater-flow model could be improved in several ways. These improvements can be classified in one of two ways: as limitations to address or as potential enhancements. In terms of limitations, the model could benefit from additional hydrogeologic and observational data. There is a substantial amount of information related to the detailed hydrostratigraphy of the tidal Anacostia River watershed (Ator and others, 2020; Layne Geosciences, Inc., 1998; MACTEC Engineering and Consulting, Inc., 2005; Tenbus, 2003), and additional study of the nature and extent of paleochannels and anthropogenic modifications that could be used to refine the model framework and conduct additional refined simulations using tools such as Local Grid Refinement (LGR) (Mehl and Hill, 2006, 2007; Raffensperger and others, 2010). A transient model could also be developed based on the steady-state model that incorporates long-term changes in boundary conditions due to pumping effects, climate change, and climate variation, as well as short-term variations caused by weather and tides. Because of the interest in delineating flow paths to the tidal Anacostia River, simulations incorporating solute transport or particle tracking (Pollock, 1994) might provide insight into detailed patterns of subsurface flow that hydraulic heads and gradients alone can not. Finally, given that the model was calibrated by using current methods that take advantage of parameter uncertainty and sensitivity analysis, tools such as OPR/PPR (Tonkin and others, 2007) could be used to evaluate the relative importance of various kinds of data to simulated predictions, therefore providing important guidance on future data collection and model re-calibration.

\section{Summary and Conclusions}

In this study, the U.S. Geological Survey (USGS), in cooperation with the District Department of Energy \&
Environment (DOEE), constructed a three-dimensional steadystate groundwater-flow model for the Anacostia River and surrounding watersheds in Washington, D.C., Maryland, and Virginia. The goal of the modeling study was to quantify the rate and pattern of groundwater flow to the tidal Anacostia River. The model was constructed and simulated by using the newly released Newton version of the USGS code MODFLOW. The model domain includes weathered and unweathered rocks of the Piedmont Physiographic Province and the southeastdipping sediments of the Atlantic Coastal Plain Physiographic Province. The model includes layer geometry for the Coastal Plain from the recently published Maryland Geological Survey Hydrogeologic Framework and incorporates processes of recharge, evapotranspiration, withdrawals from wells, and base flow to streams, rivers, and tidal waters.

Initial model property estimates were derived from literature values, results of other calibrated modeling efforts, and a manual calibration of an earlier and coarser resolution model. Final model calibration was achieved using the objective parameter estimation and sensitivity analysis capabilities of UCODE_2005. The model was calibrated to 4 estimates of base flow to streams and 34 observed water levels, using errorbased weighting. Because of the limited number of observations and the large number of highly correlated parameters, only seven parameters could be reliably estimated: the horizontal hydraulic conductivity of layers 1 (HK_11), 4 (HK_41), and 7 (HK_71), the vertical hydraulic conductivity of layer 6 (VK_61), the drain conductance of layer 1 (DRN_1), and the parameters determining the values of recharge to layer 1 ( $\mathrm{RCH}_{-}$1) and layer 8 ( $\left.\mathrm{RCH}_{-} 8\right)$. Model fit was evaluated by examining the behavior of both weighted and unweighted residuals, using measures of goodness of fit, probabilistic distribution, and degree of heteroscedasticity.

The simulated hydraulic gradients in the surficial aquifer in the vicinity of the tidal Anacostia River indicate that flow is predominantly toward the river, especially on the southeastern side, but with changes in the magnitude and direction of the gradients from the northeast, where the Anacostia River enters Washington, D.C., to the southwest, toward the confluence with the tidal Potomac River. Flow paths to the tidal Anacostia River from the north are largely horizontal through the surficial aquifer and relatively permeable Patuxent aquifer. From the south, the flow paths toward the river largely originate in the elevated topographic areas southeast of the river and pass through the surficial aquifer and Patapsco confining unit, lower Patapsco aquifer/Arundel Clay, and to some extent, the Patuxent aquifer. The rate of groundwater flow to and from the tidal Potomac and Anacostia Rivers is generally greatest near the land-water boundary, where the gradient in the water table is greatest, and diminishes toward the middle of the tidal rivers.

The tidal Potomac and Anacostia Rivers are predominantly areas of groundwater discharge, although there are areas where tidal waters recharge the subsurface, typically where small variations or depressions in the topography produce small locally reversed gradients in the water table. 
Substantial recharge of the groundwater system from tidal waters is observed for the tidal Potomac River where the upper Patapsco aquifer subcrops south of Washington, D.C. Waterbudget calculations indicate that inflows to the groundwater system beneath the tidal Anacostia River are predominantly from the surficial aquifer in Washington, D.C., followed by tidal surface water and flows from crystalline bedrock and deeper Coastal Plain aquifers. Outflows are largely to the tidal Anacostia River, with a smaller part going to the surficial aquifer in Washington, D.C. These budget quantities are consistent with the patterns of flow seen in cross section and with the patterns of gains and losses from tidal waters.

\section{References Cited}

Achmad, G., and Hansen, H.J., 2001, Ground-water levels and pumpage trends in the major Coastal Plain aquifers of southern Maryland between 1970 and 1996: Maryland Geological Survey Open-File Report 2000-02-12, 149 p., accessed July 29, 2020, at http://www.mgs.md.gov/publications/report_pages/OFR_2000-02-12.html.

Anderson, M.P., and Woessner, W.W., 1992, Applied groundwater modeling: Simulation of flow and advective transport: San Diego, Academic Press, 381 p.

Andreasen, D.C., 2002, Hydrogeology, water quality, and water-supply potential of the Aquia and Magothy aquifers in southern Anne Arundel County, Maryland: Maryland Geological Survey Report of Investigations No. 74, 110 p., accessed July 29, 2020, at http://www.mgs.md.gov/publications/report_pages/RI_74.html.

Andreasen, D.C., Staley, A.W., and Achmad, G., 2013, Maryland Coastal Plain aquifer information system: hydrogeologic framework: Maryland Geological Survey Open-File Report No. 12-02-20, 128 p., accessed July 19, 2019, at http://www.mgs.md.gov/publications/report_pages/ OFR_12-02-20.html.

Ator, S.W., Denver, J.M., and Dieter, C.A., 2020, Hydrogeology and shallow groundwater quality in the tidal Anacostia River watershed, Washington, D.C.: U.S. Geological Survey Scientific Investigations Report 2019-5128, 93 p., accessed July 29, 2020, at https://doi.org/10.3133/sir20195128.

Behm, P., Buckley, A., and Schultz, C.L., 2003, TAM/WASP toxics screening level model for the tidal portion of the Anacostia River - Final report: Rockville, Maryland: Interstate Commission on the Potomac River Basin Report No. 03-2, 199 p., accessed September 30, 2019, at https://www.potomacriver.org/wp-content/uploads/2014/12/ICPRB03-2.pdf.

Bratton, J.F., 2010, The three scales of submarine groundwater flow and discharge across passive continental margins: The Journal of Geology, v. 118, no. 5, p. 565-575, accessed July 29, 2020, at http://www.journals.uchicago.edu/doi/ abs/10.1086/655114.

Brenner, G.J., 1963, The spores and pollen of the Potomac Group of Maryland: Maryland Department of Geology, Mines, and Water Resources Bulletin 27, 215 p.

Clark, W.B., 1897, Outline of present knowledge of the physical features of Maryland, embracing an account of the physiography, geology and natural resources: Maryland Geological Survey v. 1, p. 139-228. 
Cooke, C.W., Martin, R.O.R., and Meyer, G., 1952, Geology and water resources of Prince Georges County: State of Maryland Department of Geology, Mines, and Water Resources Bulletin 10, 270 p., accessed September 30, 2019, at http:/www.mgs.md.gov/publications/report pages/ BULL_10.html.

Cooley, R.L., Konikow, L.F., and Naff, R.L., 1986, Nonlinearregression groundwater flow modeling of a deep regional aquifer system: Water Resources Research, v. 22, no. 13, p. 1759-1778, accessed July 30, 2020, at http://dx.doi. org/10.1029/WR022i013p01759.

Curtin, S.E., Andreasen, D.C., and Staley, A.W., 2012, Potentiometric surface and water-level difference maps of selected confined aquifers in Southern Maryland and Maryland's Eastern Shore, 1975-2011: U.S. Geological Survey Scientific Investigations Report 2012-5165, 36 p., (also available online at http://pubs.usgs.gov/sir/2012/5165/).

Cushing, E.M., Kantrowitz, I.H., and Taylor, K.R., 1973, Water resources of the Delmarva Peninsula: Washington D.C.: U.S. Geological Survey Professional Paper 822, 58 p., 12 pls., accessed July 29, 2020, at https://doi.org/10.3133/ pp822.

D'Agnese, F.A., Faunt, C.C., Hill, M.C., and Turner, A.K, 1999, Death valley regional ground-water flow model calibration using optimal parameter estimation methods and geoscientific information systems: Advances in Water Resources, v. 22, no. 8, p. 777-790, accessed July 30, 2020, at https://doi.org/10.1016/S0309-1708(98)00053-0.

Darton, N.H., 1950, Configuration of the bedrock surface of the District of Columbia and vicinity: U.S. Geological Survey Professional Paper 217, 42 p., accessed September 27, 2012, at https://doi.org/10.3133/pp217.

Dausman, A.M., Doherty, J., Langevin, C.D., and Sukop, M.C., 2010, Quantifying data worth toward reducing predictive uncertainty: Ground Water, v. 48, no. 5, p. 729-740, accessed July 30, 2020, at https://doi.org/10.1111/j.17456584.2010.00679.x.

Dicken, C.L., Nicholson, S.W., Horton, J.D., Kinney, S.A., Gunther, G., Foose, M.P., and Mueller, J.A.L., 2005, Preliminary integrated geologic map databases for the United States: Delaware, Maryland, New York, Pennsylvania, and Virginia: U.S. Geological Survey Open-File Report 20051325 (ver. 1.1), accessed September 27, 2012, at https://doi. org/10.3133/ofr20051325.

District of Columbia Office of Planning, 2009, DC GIS Data Clearinghouse/Catalog, accessed April 15, 2009, at http:// dcatlas.dcgis.dc.gov/catalog/.

Draper, N.R., and Smith, H., 1998, Applied regression analysis (3d ed.): New York, John Wiley \& Sons, Inc., 706 p.
Drummond, D.D., 2007, Water-supply potential of the Coastal Plain aquifers in Calvert, Charles, and St. Mary's Counties, Maryland, with emphasis on the Upper Patapsco and Lower Patapsco aquifers: Maryland Geological Survey Report of Investigations No. 76, 236 p., accessed September 30, 2019, at http://www.mgs.md.gov/publications/report_pages/ RI_76.html.

Faunt, C.C., Blainey, J.B., Hill, M.C., D'Agnese, F.A., and O'Brien, G.M., 2004, Transient numerical model, chap. F of Belcher, W.R., ed., Death Valley regional ground-water flow system, Nevada and California-Hydrogeologic framework and transient ground-water flow model: U.S. Geological Survey Scientific Investigations Report 2004-5205, 408 p., 2 pls., accessed September 27, 2012, at https://doi. org/10.3133/sir20045205.

Fienen, M.N., D’Oria, M., Doherty, J.E., and Hunt, R.J., 2013, Approaches in highly parameterized inversion: bgaPEST, a Bayesian geostatistical approach implementation with PEST-Documentation and instructions: U.S. Geological Survey Techniques and Methods, book 7, section C9, 86 p., accessed July 29, 2020, at http://pubs.usgs.gov/tm/07/c09.

Fienen, M.N., Doherty, J.E., Hunt, R.J., and Reeves, H.W., 2010, Using prediction uncertainty analysis to design hydrologic monitoring networks: Example applications from the Great Lakes Water Availability Pilot Project: U.S. Geological Survey Scientific Investigations Report 20105159, 44 p., accessed July 29, 2020, at http://pubs.usgs.gov/ $\operatorname{sir} / 2010 / 5159$.

Fleck, W.B., and Vroblesky, D.A., 1996, Simulation of ground-water flow of the Coastal Plain aquifers in parts of Maryland, Delaware, and the District of Columbia: U.S. Geological Survey Professional Paper 1404-J, 41 p., accessed April 4, 2018, at https://doi.org/10.3133/pp1404J.

Fleming, B.J., Hammond, P.A., Stranko, S.A., Duigon, M.T., and Kasraei, S., 2012, A science plan for a comprehensive assessment of water supply in the region underlain by fractured rock in Maryland: U.S. Geological Survey Scientific Investigations Report 2012-5160, 29 p., accessed July 22, 2015, at http://pubs.usgs.gov/sir/2012/5160/.

Glaser, J.D., 1969, Petrology and origin of Potomac and Magothy (Cretaceous) sediments, middle Atlantic Coastal Plain: Maryland Geological Survey Report of Investigations No. 11, 101 p., accessed July 30, 2020, at http://www.mgs. md.gov/publications/report_pages/RI_11.html.

Glaser, J.D., 1976, Geologic Map of Anne Arundel County: Maryland Geological Survey Atlas Map No. 1, scale 1:62,500, accessed July 30, 2020, at http://jhir.library.jhu. edu/handle/1774.2/34566. 
Hansen, H.J., 1972, A user's guide for the artesian aquifers of the Maryland Coastal Plain, Part Two: aquifer characteristics: Maryland Geological Survey Open-File Report No. 72-02-1, 123 p., accessed July 29, 2020, at http://www.mgs. md.gov/publications/report_pages/OFR_72-02-1.html.

Hansen, H.J., 1974, Sedimentary facies of the Aquia Formation in the subsurface of the Maryland Coastal Plain: Maryland Geological Survey Report of Investigations No. 21, 47 p., accessed July 29, 2020, at http://www.mgs.md.gov/ publications/report_pages/RI_21.html.

Harbaugh, A.W., 1990, A computer program for calculating subregional water budgets using results from the U.S. Geological Survey Modular Three-Dimensional Finite-Difference Ground-Water Flow Model: U.S. Geological Survey Open-File Report 90-392, 46 p., accessed September 27, 2010, at https://doi.org/10.3133/ofr90392.

Harbaugh, A.W., 2005, MODFLOW-2005, The U.S. Geological Survey modular ground-water model - the GroundWater Flow Process: U.S. Geological Survey Techniques and Methods 6-A16, [variously paged], accessed September 27, 2010, at http://pubs.er.usgs.gov/publication/tm6A16.

Harbaugh, A.W., Banta, E.R., Hill, M.C., and McDonald, M.G., 2000, MODFLOW-2000, The U.S. Geological Survey modular ground-water model-user guide to modularization concepts and the ground-water flow process: U.S. Geological Survey Open-File Report 2000-92, 121 p., accessed September 27, 2010, at https://doi.org/10.3133/ ofr200092.

Harned, D.A., and Daniel, C.C., III, 1992, The transition zone between bedrock and regolith: conduit for contamination?, in Daniel, C.C., III, White, R.K., and Stone, P.A., eds., Ground Water in the Piedmont: Proceedings of a Conference on Ground Water in the Piedmont of the Eastern United States, Charlotte, North Carolina, October 16-18, 1989: Clemson, South Carolina, Clemson University, p. 336-348.

Hill, M.C., 1998, Methods and guidelines for effective model calibration; with application to UCODE, a computer code for universal inverse modeling, and MODFLOWP, a computer code for inverse modeling with MODFLOW: U.S. Geological Survey Water-Resources Investigations Report 98-4005, 90 p., accessed September 27, 2011, at https://doi. org/10.3133/wri984005.

Hill, M.C., Banta, E.R., Harbaugh, A.W., and Anderman, E.R., 2000, MODFLOW-2000, the U.S. Geological Survey modular ground-water model - User guide to the observation, sensitivity, and parameter-estimation processes and three post-processing programs: U.S. Geological Survey Open-File Report 2000-184, 209 p., accessed September 20, 2010, at https://doi.org/10.3133/ofr00184.
Hill, M.C., Cooley, R.L., and Pollock, D.W., 1998, A controlled experiment in ground water flow model calibration: Ground Water, v. 36, no. 3, p. 520-535, accessed October 22, 2011, at http://dx.doi.org/10.1111/j.1745-6584.1998. tb02824.x.

Hill, M.C., and Tiedeman, C.R., 2007, Effective groundwater model calibration: With analysis of data, sensitivities, predictions, and uncertainty: Hoboken, New Jersey, John Wiley \& Sons, $455 \mathrm{p}$.

Hughes, J.D., Langevin, C.D., Chartier, K.L., and White, J.T., 2012, Documentation of the Surface-Water Routing (SWR1) Process for modeling surface-water flow with the U.S. Geological Survey Modular Ground-Water Model (MODFLOW-2005): U.S. Geological Survey Techniques and Methods book 6, chap. A40 (Version 1.0), 113 p., accessed July 22, 2014, at http://pubs.usgs.gov/tm/6a40/.

Johnston, P.M., 1964, Geology and ground-water resources of Washington, D.C. and vicinity: U.S. Geological Survey Water-Supply Paper 1776, 98 p., accessed September 30, 2019, at https://doi.org/10.3133/wsp1776.

Klohe, C.A., and Debrewer, L.M., 2007, Summary of groundwater-quality data in the Anacostia River Watershed, Washington, D.C., September-December 2005: U.S. Geological Survey Open-File Report 2006-1392, 64 p., accessed September 30, 2019, at http://pubs.usgs.gov/of/2006/1392/.

Layne Geosciences, Inc., 1998, Ground water development report, DC Aquatic Resource Education Center, Well PW-1, Anacostia Park, Washington D.C.: National Park Service, [variously paged].

Lewis-Brown, J.C., and Jacobsen, E., 1995, Hydrogeology and ground-water flow, fractured Mesozoic structuralbasin rocks, Stony Brook, Beden Brook, and Jacobs Creek drainage basins, west-central New Jersey: U.S. Geological Survey Water-Resources Investigations Report 94-4147, 83 p., accessed July 23, 2011, at http://pubs.er.usgs.gov/publication/wri944147.

Logan, W.S., 1999, Estimation of shallow groundwater flux to the Anacostia River: District of Columbia Environmental Health Administration, Water Quality Division, 48 p.

Mack, F.K., 1974, An evaluation of the Magothy aquifer in the Annapolis area, Maryland: Maryland Geological Survey Report of Investigations No. 22, 75 p., accessed July 29, 2020, at http://www.mgs.md.gov/publications/report_pages/ RI_22.html.

Mack, F.K., and Mandle, R.J., 1977, Digital simulation and prediction of water level in the Magothy aquifer in Southern Maryland: Maryland Geological Survey Report of Investigations No. 28, 42 p., accessed July 29, 2020, at http:// www.mgs.md.gov/publications/report_pages/RI_28.html. 
Mack, F.K., and Achmad, G., 1986, Evaluation of the watersupply potential of aquifers in the Potomac Group of Anne Arundel County, Maryland: Maryland Geological Survey Report of Investigations No. 46, 111 p., accessed July 29, 2020, at http://www.mgs.md.gov/publications/report_pages/ RI_46.html.

MACTEC Engineering and Consulting Inc., 2005, Preliminary geotechnical services-South Capitol Street bridge, Washington, D.C.: Arlington, Virginia, HNTB, Inc., [variously paged].

Maryland Department of Planning, 2009, Land Use/Land Cover, accessed April 8, 2009, at http://www.mdp.state. md.us/OurWork/landUseDownload.shtml.

Matheson, G.M., Schneider, J., Zmijewski, D., and Amini, F., 1994, Definition of groundwater flow in the water table aquifer of the southern Anacostia River Basin: Washington, D.C.: D.C. Water Resources Research Center Report No. 147, 42 p., accessed April 4, 2019, at http://www.udc.edu/ docs/dc_water_resources/technical_reports/report_n_147. pdf.

Matheson, G.M., Schneider, J., and Zmijewski, D., 1995, Development of a groundwater contour map for the water table aquifer in the Atlantic Coastal Plain deposits of Washington, D.C.: D.C. Water Resources Research Center Report No. 156, 74 p., accessed April 4, 2019, at http:// www.udc.edu/docs/dc_water_resources/technical_reports/ Report_N_156.pdf.

Mehl, S.W., and Hill, M.C., 2006, MODFLOW-2005, the U.S. Geological Survey modular ground-water model - documentation of shared node local grid refinement (LGR) and the boundary flow and head (BFH) package: U.S. Geological Survey Techniques and Methods 6-A12, 78 p., accessed April 2, 2011, at https://doi.org/10.3133/tm6A12.

Mehl, S.W., and Hill, M.C., 2007, MODFLOW-2005, the U.S. Geological Survey Modular Ground-Water Model - Documentation of the multiple-refined-areas capability of Local Grid Refinement (LGR) and the Boundary Flow and Head (BFH) Package: U.S. Geological Survey Techniques and Methods 6-A21, 13 p., accessed April 2, 2011, at https:// doi.org/10.3133/tm6A21.

Miller, C.V., and Klohe, C.A., 2003, Summary of waterand sediment-quality data for Anacostia River well sites sampled in July-August 2002: U.S. Geological Survey Open-File Report 2003-73, 48 p., accessed April 2, 2011, at http://pubs.usgs.gov/of/2003/ofr03-073/.

Niswonger, R.G., Panday, S., and Ibaraki, M., 2011, MODFLOW-NWT, A Newton formulation for MODFLOW-2005: U.S. Geological Survey Techniques and Methods 6-A37, 44 p., accessed April 2, 2011, at http://pubs.usgs.gov/tm/ tm6a37/.
Niswonger, R.G., and Prudic, D.E., 2005, Documentation of the Streamflow-Routing (SFR2) Package to include unsaturated flow beneath streams-A modification to SFR1: U.S. Geological Survey Techniques and Methods 6-A13, 47 p., accessed April 2, 2011, at https://doi.org/10.3133/tm6A13.

Niswonger, R.G., Prudic, D.E., and Regan, R.S., 2006, Documentation of the Unsaturated-Zone Flow (UZF1) Package for modeling unsaturated flow between the land surface and the water table with MODFLOW-2005: U.S. Geological Survey Techniques and Methods 6-A19, 74 p., accessed April 2, 2011, at https://doi.org/10.3133/tm6A19.

Nogan, D.S., 1964, Foraminifera, stratigraphy, and paleoecology of the Aquia Formation of Maryland and Virginia: Washington, D.C., Cushman Foundation for Foraminiferal Research, Smithsonian Institution, Special Publication no. $7,50 \mathrm{p}$.

Papadopulos, S.S., Bennett, R.R., Mack, F.K., and Trescott, P.C., 1974, Water from the Coastal Plain aquifers in the Washington, D.C., metropolitan area: U.S. Geological Survey Circular 697, 11 p., accessed September 30, 2019, at https://pubs.usgs.gov/circ/1974/0697/report.pdf.

Plummer, L.N., Eggleston, J.R., Andreasen, D.C., Raffensperger, J.P., Hunt, A.G., and Casile, G.C., 2012, Old groundwater in parts of the upper Patapsco aquifer, Atlantic Coastal Plain, Maryland, USA: evidence from radiocarbon, chlorine-36 and helium-4: Hydrogeology Journal, v. 20, no. 7, p. 1269-1294, accessed September 27, 2019, at http:// dx.doi.org/10.1007/s10040-012-0871-1.

Poeter, E.P., and Hill, M.C., 1997, Inverse models: a necessary next step in ground-water modeling: Ground Water, v. 35, no. 2, p. 250-260, accessed July 30, 2020, at http://inside. mines.edu/ epoeter/pubs/1997/gw-inverse/.

Poeter, E.P., and Hill, M.C., 1998, Documentation of UCODE, a computer code for universal inverse modeling: U.S. Geological Survey Water-Resources Investigations Report 98-4080, 116 p., accessed July 20, 2019, at https://doi. org/10.3133/wri984080.

Poeter, E.P., and Hill, M.C., 1999, UCODE, A computer code for universal inverse modeling: Computers \& Geosciences, v. 25 , no. 4, p. 457-462, accessed July 30, 2020, at https:// doi.org/10.1016/S0098-3004(98)00149-6.

Poeter, E.P., Hill, M.C., Banta, E.R., Mehl, S., and Christensen, S., 2005, UCODE_2005 and six other computer codes for universal sensitivity analysis, calibration, and uncertainty evaluation: U.S. Geological Survey Techniques and Methods 6-A11, 283 p., accessed September 27, 2012, at https://doi.org/10.3133/tm6A11. 
Pollock, D.W., 1994, User's Guide for MODPATH/MODPATH-PLOT, Version 3: A particle tracking post-processing package for MODFLOW, the U.S. Geological Survey finite-difference ground-water flow model: U.S. Geological Survey Open-File Report 94-464, [variously paged].

Raffensperger, J.P., Fleming, B.J., Banks, W.S.L., Horn, M.A., Nardi, M.R., and Andreasen, D.C., 2010, Simulation of groundwater flow to assess future withdrawals associated with Base Realignment and Closure (BRAC) at Fort George G. Meade, Maryland: U.S. Geological Survey Scientific Investigations Report 2010-5186, 48 p., accessed September 29, 2013, at https://pubs.usgs.gov/sir/2010/5186/.

Reilly, T.E., 2001, System and boundary conceptualization in ground-water flow simulation: U.S. Geological Survey Techniques of Water-Resources Investigations of the United States Geological Survey, book 3, chap. B8, 29 p., accessed September 29, 2013, at https://doi.org/10.3133/twri03B8.

Risser, D.W., 2008, Spatial distribution of ground-water recharge estimated with a water-budget method for the Jordan Creek Watershed, Lehigh County, Pennsylvania: U.S. Geological Survey Scientific Investigations Report 2008-5041, 26 p., accessed September 29, 2013, at https:// doi.org/10.3133/sir20085041.

Rutledge, A.T., 1998, Computer programs for describing the recession of ground-water discharge and for estimating mean ground-water recharge and discharge from streamflow records-update: U.S. Geological Survey Water-Resources Investigations Report 98-4148, 43 p., accessed March 16, 2017, at https://pubs.er.usgs.gov/publication/wri984148.

San Juan, C.A., Belcher, W.R., Laczniak, R.J., and Putnam, H.M., 2004, Hydrologic components for model development, chap. C. of Belcher, W.R., ed., Death Valley regional ground-water flow system, Nevada and California-hydrogeologic framework and transient ground-water flow model: U.S. Geological Survey Scientific Investigations Report 2004-5205, accessed September 29, 2013, at https://doi. org/10.3133/sir20045205.

Sanford, W.E., Nelms, D.L., Pope, J.P., and Selnick, D.L., 2012a, Quantifying components of the hydrologic cycle in Virginia using chemical hydrograph separation and multiple regression analysis: U.S. Geological Survey Scientific Investigations Report 2011-5198, 152 p., accessed September 4, 2013, at http://pubs.usgs.gov/sir/2011/5198/.

Sanford, W.E., Plummer, L.N., McAda, D.P., Bexfield, L.M., and Anderholm, S.K., 2004, Hydrochemical tracers in the middle Rio Grande Basin, USA: 2. Calibration of a groundwater-flow model: Hydrogeology Journal, v. 12, no. 4, p. 389-407, accessed July 30, 2020, at http://dx.doi. org/10.1007/s10040-004-0326-4.
Sanford, W.E., Pope, J.P., Selnick, D.L., and Stumvoll, R.F., 2012b, Simulation of groundwater flow in the shallow aquifer system of the Delmarva Peninsula, Maryland and Delaware: U.S. Geological Survey Open-File Report 2012-1140, 58 p., accessed September 22, 2014, at https:// doi.org/10.3133/ofr20121140.

Schneider, J., Watt, H.M., O’Connor, J.V., Chang, F.M., and Wade, C.W., 1993, Ground water resource assessment study for the District of Columbia, Final Report: D.C. Water Resources Research Center Technical Report No. 145, 97 p., accessed October 4, 2010, at http://www.udc.edu/docs/ dc_water_resources/technical_reports/report_n_145.pdf.

Soeder, D.J., Raffensperger, J.P., and Nardi, M.R., 2007, Effects of withdrawals on ground-water levels in southern Maryland and the adjacent Eastern Shore, 1980-2005: U.S. Geological Survey Scientific Investigations Report 20075249, 83 p., accessed November 22, 2010, at https://pubs. usgs.gov/sir/2007/5249/.

Southworth, S., and Denenny, D., 2006, Geologic map of the National Parks in the National Capital Region, Washington, D.C., Virginia, Maryland, and West Virginia: U.S. Geological Survey Open-File Report 2005-1331, accessed October 1, 2019, at http://pubs.usgs.gov/of/2005/1331/.

Swain, L.A., Mesko, T.O., and Hollyday, E.F., 2004, Summary of the hydrogeology of the Valley and Ridge, Blue Ridge, and Piedmont Physiographic Provinces in the Eastern United States: U.S. Geological Survey Professional Paper 1422-A, 23 p., accessed November 22, 2012, at https://doi. org/10.3133/pp1422A.

Tenbus, F.J., 2003, Lithologic coring in the lower Anacostia tidal watershed, Washington, D.C., July 2002: U.S. Geological Survey Open-File Report 2003-318, 62 p., accessed October 1, 2019, at http://pubs.usgs.gov/of/2003/ofr03-318/.

Tonkin, M.J., Tiedeman, C.R., Ely, D.M., and Hill, M.C., 2007, OPR-PPR, a computer program for assessing data importance to model predictions using linear statistics: U.S. Geological Survey Techniques and Methods TM-6E2, 115 p., accessed May 4, 2010, at https://doi.org/10.3133/tm6E2.

Tóth, J., 1962, A theory of groundwater motion in small drainage basins in central Alberta, Canada: Journal of Geophysical Research, v. 67, no. 11, p. 4375-4387, accessed July 30, 2020, at https://doi.org/10.1029/JZ067i011p04375.

Tóth, J., 1963, A theoretical analysis of groundwater flow in small drainage basins: Journal of Geophysical Research, v. 68 , no. 16, p. 4795-4812, accessed July 30, 2020, at https:// doi.org/10.1029/JZ068i016p04795.

U.S. Environmental Protection Agency, 2007, National Hydrography Dataset Plus-NHDPlus version 1.1, accessed March 31, 2010 at http://www.horizon-systems.com/nhdplus. 
U.S. Geological Survey, 2006, National Elevation Dataset, accessed April 8, 2009, at http://ned.usgs.gov/.

Velinsky, D.J., Wade, T.L., Schlekat, C.E., McGee, B.L., and Presley, B.J., 1994, Tidal river sediments in the Washington, D.C. area. I. Distribution and sources of trace metals: Estuaries, v. 17, no. 2, p. 305-320, accessed July 30, 2020, at https://doi.org/10.2307/1352665.

Vroblesky, D.A., and Fleck, W.B., 1991, Hydrogeologic framework of the Coastal Plain of Maryland, Delaware, and the District of Columbia: U.S. Geological Survey Professional Paper 1404-E, 45 p., accessed October 1, 2019, at https://doi.org/10.3133/pp1404E.

Washington Metropolitan Area Transit Authority, 1981, Anacostia river crossing branch route subsurface investigation: Washington, D.C., Washington Metropolitan Area Transit Authority, Report No. 8, 17 p.

Weigle, J.M., Webb, W.E., and Gardner, R.A., 1970, Water resources of Southern Maryland: U.S. Geological Survey Hydrologic Atlas HA-465, 3 pls., accessed June 22, 2009, at https://doi.org/10.3133/ha365.

Westenbroek, S.M., Kelson, V.A., Dripps, W.R., Hunt, R.J., and Bradbury, K.R., 2010, SWB-A modified Thornthwaite-Mather Soil-Water-Balance code for estimating groundwater recharge: U.S. Geological Survey Techniques and Methods 6-A31, 60 p., accessed June 15, 2011, at https://doi.org/10.3133/tm6A31.

Williams, G.P., 1977, Washington, D.C.'s vanishing springs and waterways: U.S. Geological Survey Circular 752, 19 p., accessed June 18, 2010, at https://doi.org/10.3133/cir752. 

For additional information contact:

Director, MD-DE-DC Water Science Center 5522 Research Park Drive

Baltimore, MD 21228

Or visit our website at: https://www.usgs.gov/centers/md-de-dc-water

Publishing support provided by the U.S. Geological Survey Science Publishing Network, West Trenton Publishing Service Center 
